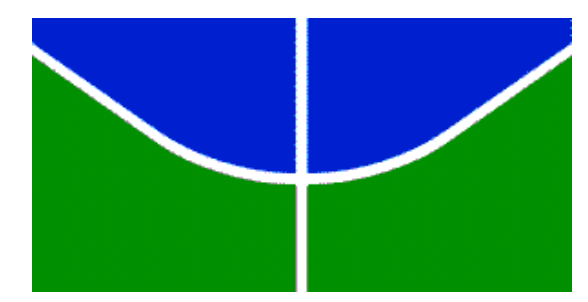

Universidade de Brasília

Centro de Excelência em Turismo

Programa de Pós Graduação em Turismo

Mestrado Profissional em Turismo

LÍVIA CRISTINA BARROS DA SILVA WIESINIESKI

POLÍTICAS PÚBLICAS DO SETOR HIDRELÉTRICO COMO FERRAMENTA PARA O DESENVOLVIMENTO SUSTENTÁVEL DO TURISMO EM REGIÕES ATINGIDAS POR BARRAGEM

Brasília 


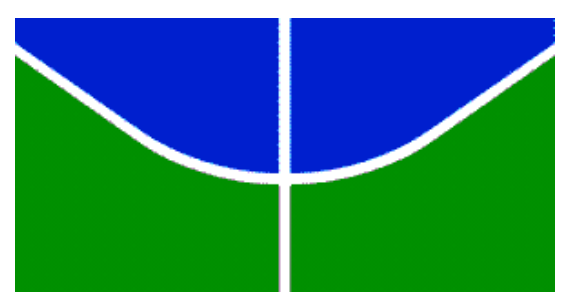

Universidade de Brasília

Centro de Excelência em Turismo

Programa de Pós Graduação em Turismo

Mestrado Profissional em Turismo

\section{POLÍTICAS PÚBLICAS DO SETOR HIDRELÉTRICO COMO FERRAMENTA PARA O DESENVOLVIMENTO SUSTENTÁVEL DO TURISMO EM REGIÕES ATINGIDAS POR BARRAGEM}
Dissertação apresentada ao Programa de Mestrado Profissional em Turismo da Universidade de Brasília, área de concentração Turismo, Cultura e Desenvolvimento Regional, na linha de pesquisa de Desenvolvimento, Políticas Públicas e Gestão no Turismo, como requisito parcial para obtenção do título de mestre.

Orientadora: Dra. lara Lúcia Gomes Brasileiro 
Ficha catalográfica elaborada pela Biblioteca Central da Universidade de Brasília. Acervo 1020800.

Wiesinieski , Lívia Cr ist ina Bar ros da Si lva.

W651p Pol í $\mathrm{i}$ cas públ icas do setor hidrelét $r$ ico como fer ramenta para o desenvol vimento sustentável do tur i smo em regiões at ingidas por bar ragem / Lívia $\mathrm{Cr}$ ist ina Bar ros da Si lva Wiesinieski . - 2015.

$121 \mathrm{f}$. : il . ; $30 \mathrm{~cm}$.

Disser tação (mest rado) - Uni versidade de Brasí l ia, Cent ro de Excelência em Tur i smo, Programa de Pósgraduação em

Tur ismo, Mest rado Prof issional em Tur ismo, 2015.

Or ientação: lara Lúcia Gomes Brasi lei ro.

Inclui bibl iograf ia.

1. Tur ismo. 2. Pol í $\mathrm{t}$ i ca públ ica. 3. Desenvolvimento sustentável. 4. Bar ragens de ter ra. I. Brasi lei ro, lara Lúcia Gomes. I I. Tí tulo. 


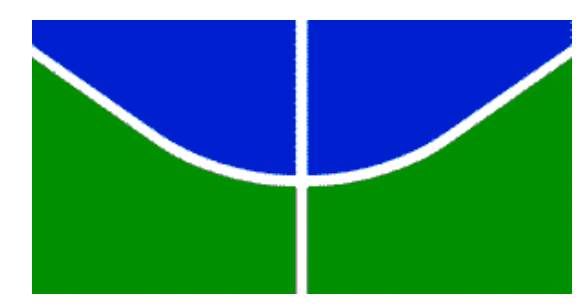

\author{
Universidade de Brasília \\ Centro de Excelência em Turismo \\ Programa de Pós Graduação em urismo \\ Mestrado Profissional em Turismo
}

\begin{abstract}
Dissertação de autoria de Lívia Cristina Barros da Silva Wiesinieski, intitulada Políticas públicas do setor hidrelétrico como ferramenta para o desenvolvimento sustentável do turismo em regiões atingidas por barragem, submetida ao Centro de Excelência em Turismo da Universidade de Brasília, como parte dos requisitos necessários para obtenção do grau de Mestre em Turismo, em 03/03/2015, defendida e aprovada pela banca examinadora abaixo assinada.
\end{abstract}

Profa. Dra. Iara Lúcia Gomes Brasileiro Orientadora CET/UNB

Prof. Dr. José Aroudo Mota

Avaliador Externo

Prof. Dr. João Paulo Faria Tasso

Avaliador Externo 
Dedico esta dissertação aos meus pais, ao Luiz Antônio e especialmente ao Mário e ao Mateus. 


\section{AGRADECIMENTOS}

Agradeço a Deus por ter me mostrado a hora exata de correr atrás dos meus sonhos com determinação e coragem. Em nenhum momento o Senhor me faltou e por isso minha caminhada foi cansativa, mas prazerosa.

Aos meus familiares, pais e irmão que muitas vezes escutaram minhas lamentações e dúvidas e me incentivaram a seguir em frente. Ao meu marido que mesmo nos meus momentos de estresse e cansaço tinha uma palavra amiga de apoio às minhas escolhas. Ao meu filho que me despertou para a importância de continuar a progredir na carreira profissional sem sequer me dizer uma palavra e, que sempre foi paciente nos momentos em que a mamãe dizia que agora era hora de trabalhar e estudar.

À minha querida amiga e orientadora, Profa. Dra. Iara Brasileiro que me conquistou com tamanha sabedoria e dedicação aos alunos. Você é uma pessoa mágica, sábia e dedicada à arte de ensinar.

Meu muito obrigado à equipe do CET que me recebeu de braços abertos, com muito carinho. Em especial aos professores Karina Dias, Luiz Carlos Spiller, Marutschka Moesch, e aos colaboradores Luiz Lucena e Tatielle.

Por fim aos meus fiéis amigos que durante esta trajetória me proporcionaram momentos de prazer e alegria sem nada me pedir em troca, pois sabiam que o tempo às vezes não era suficiente para todos os encontros de que eu gostaria de participar. 
Todos têm direito ao meio ambiente ecologicamente equilibrado, bem de uso comum do povo e essencial à sadia qualidade de vida, impondo-se ao Poder Público e à coletividade o dever de defendê-lo e preservá-lo para as presentes e futuras gerações. $\S 1^{\circ}$ - Para assegurar a efetividade desse direito, incumbe ao Poder Público: IV - exigir, na forma da lei, para instalação de obra ou atividade potencialmente causadora de significativa degradação do meio ambiente, estudo prévio de impacto ambiental, a que se dará publicidade; (Lei no 11.105, de 24 de março de 2005, Art. 225.) 


\section{RESUMO}

Com base nos princípios da sustentabilidade dos recursos naturais, particularmente, da água, de forma continuada e múltipla, têm sido propostas políticas públicas voltadas para o setor hidrelétrico do Brasil. No caso de barragens, existem diferentes atividades que podem ser desenvolvidas tanto nos lagos quanto em seu entorno. De modo geral, o discurso é de desenvolvimento econômico e social de localidades marginalizadas. Este trabalho tem como objetivo geral analisar as políticas públicas que sugerem a prática do turismo em barragens de hidrelétricas. Discute, ainda, ações propostas para o uso do turismo nos reservatórios tendo como prioridade os interesses manifestados pela população local durante o processo de construção do Plano Ambiental de Conservação e Uso do Entorno do Reservatório Artificial/ Plano de Conservação Ambiental e Usos da Água e do Entorno do Reservatório (PACUERA/PCAU). O turismo muitas vezes é apresentado como uma possibilidade estratégica de melhoria dos equipamentos de uso coletivo, como hospitais, praças, parques e estradas, além de proporcionar o desenvolvimento local a partir da ampliação do número de empregos e da criação de novos negócios. Para responder às questões propostas, foi feita revisão bibliográfica, análise documental, entrevistas e estudo de caso - UHE Barra Grande (RS/SC) e UHE Corumbá IV (GO). Utilizou-se como ferramenta para a interpretação dos dados, o Advocacy Coalision Framework (ACF) e a triangulação. Os resultados indicaram que, apesar da legislação sugerir o uso das áreas naturais para o turismo, sua implantação nem sempre tem reflexos na realidade local. Além disso, mostraram que o incremento da atividade vem dos discursos políticos, quase nunca das comunidades atingidas pela barragem. Finalmente, o estudo reafirmou a possibilidade do uso do turismo como alternativa para o desenvolvimento e para a preservação/conservação dos recursos naturais, bem como reforçou a necessidade de articulação entre os diferentes atores: governos em suas instâncias municipal, estadual e federal, empresários e comunidade.

Palavras-chave: Políticas Públicas; Barragem; Turismo; Sustentabilidade; Desenvolvimento local 


\begin{abstract}
Based on the principles of sustainability of natural resources, particularly water continuously and multiple use, public policies have been established facing the hydroelectric sector in Brazil. In the case of dams, there are different activities that can be undertaken both in lakes and in its surroundings. In general, the speech is of economic and social development of marginalized localities. This work has as main objective to analyze public policies that suggest the practice of tourism in hydroelectric dams. Also discusses actions proposed for the use of tourism in reservoirs with priority on the interests expressed by local people during the construction process of the Environmental Plan of Conservation and Use of Surrounding Artificial Reservoir / Plan of Conservation and Use of Water and Surrounding Reservoir (PACUERA / PCAU). Tourism is often presented as a strategic potential for improving the collective use of facilities such as hospitals, squares, parks and roads, in addition to providing local development from the increase in the number of jobs and the creation of new businesses. To answer the questions posed, it was undertaken a literature review, document analysis, interviews and case study - UHE Barra Grande (RS / SC) and HPP Corumbá IV (GO). Advocacy Coalision Framework (ACF) and triangulation were used as tool for data interpretation. The results indicated that, despite legislation suggest the use of natural areas for tourism, its implementation has not always reflected in the local reality. In addition, they showed that increased activity comes from political speeches, but almost never from the communities affected by the dam. Finally, the results confirm the possibility of using tourism as an alternative to the development and preservation / conservation of natural resources and stressed the need for coordination between different actors: governments in their local, state and federal authorities, business and community.
\end{abstract}

Keywords: Public Policy; Dam; Tourism; Sustainability; Local Development 


\section{LISTA DE FIGURAS}

Figura 1 Imagem de Satélite com os municípios lindeiros UHE 68

Figura 2 Bacia de Contribuição da UHE Corumbá IV 


\section{LISTA DE QUADROS}

Quadro 1 Síntese da Constituição da República Federativa do Brasil (tópicos relevantes a essa discussão)

Quadro 2 Síntese das principais leis vigentes que contemplam a temática do meio ambiente e do turismo

Quadro 3 Síntese do decreto que contempla a temática do meio ambiente e do turismo

Quadro 4 Síntese das resoluções CONAMA e CNRH que contemplam a temática do meio ambiente e do turismo

Quadro 5 UHE Barra Grande - estrutura hierárquica das crenças

Quadro 6 UHE Corumbá IV - estrutura hierárquica das crenças 


\section{LISTA DE SIGLAS}

ABETA

ACF

ADREL

ANA

ANEEL

APP

BAESA

CEB

CONAMA

$\mathrm{CNRH}$

IBAMA

EIA

FIP/ BRB

IBGE

ICMBio

IDH

IDHM

IPEA

GO

LI

LO

LP

$M A B$

MMA

PACUERA

PCAU
Associação Brasileira das Empresas de Ecoturismo e Turismo de Aventura Advocacy Coalition Framework

Agência de Desenvolvimento da Região dos Lagos

Agência Nacional de Águas

Agência Nacional de Energia Elétrica

Área de Preservação Permanente

Energética Barra Grande S/A

Companhia Energética de Brasília

Conselho Nacional do Meio Ambiente

Conselho Nacional de Recursos Hídricos

Instituto Brasileiro do Meio Ambiente e dos Recursos

Naturais Renováveis

Estudo de Impacto Ambiental

Fundo de Pensão do Banco de Brasília

Instituto Brasileiro de Geografia e Estatística

Instituto Chico Mendes de Conservação da Biodiversidade

Índice de Desenvolvimento Humano

Índice de Desenvolvimento Humano dos Municípios

Instituto de Pesquisa Econômica Aplicada

Goiás

Licença de Instalação

Licença de Operação

Licença Prévia

Movimento dos Atingidos por Barragem

Ministério do Meio Ambiente

Plano Ambiental de Conservação e Uso do Entorno de Reservatório Artificial

Plano de Conservação Ambiental e Usos da Água e do Entorno do Reservatório

Pequenas Centrais Hidrelétricas 
PLANTUR Política Nacional de Turismo

PNUD

Programa das Nações Unidas para o Desenvolvimento

RIDE

Região Integrada de Desenvolvimento do Distrito Federal e Entorno

RIMA Relatório de Impacto Ambiental

RS

Rio Grande do Sul

SC

Santa Catarina

SNUC

Sistema Nacional de Unidades de Conservação

TERRACAP Companhia Imobiliária de Brasília

UHE

Usina Hidrelétrica 


\section{SUMÁRIO}

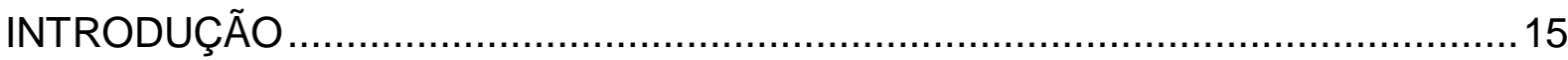

OBJETIVO GERAL

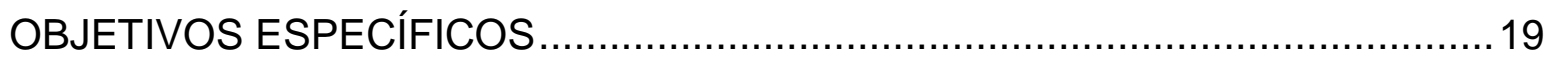

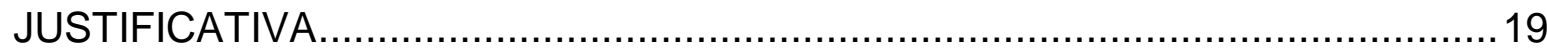

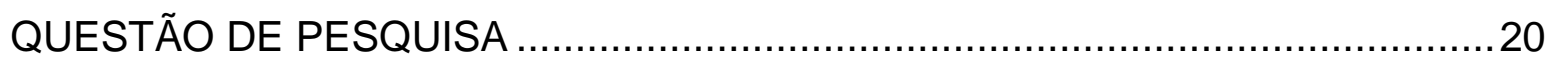

CAPÍTULO 1: BREVE DISCUSSÃO TEÓRICA SOBRE TURISMO E LAZER .........23

1.1. O ESPAÇO COMO RESULTADO DAS INTERAÇÕES ….............................25

1.2. UM OLHAR SOBRE O TURISMO E SUAS RELAÇÕES COM O MEIO .........30

1.2.1. Teoria dos sistemas como ferramenta para entendimento do fenômeno

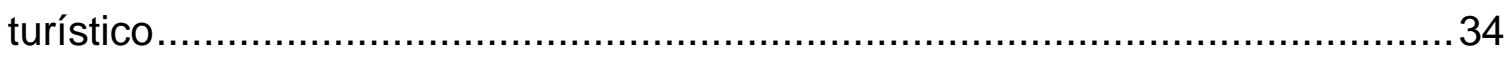

1.3. O LAZER COMO ESSÊNCIA DO TURISMO …......................................... 41

1.4. UM ENFOQUE NOS ESPAÇOS NATURAIS PARA A PRÁTICA DE LAZER E

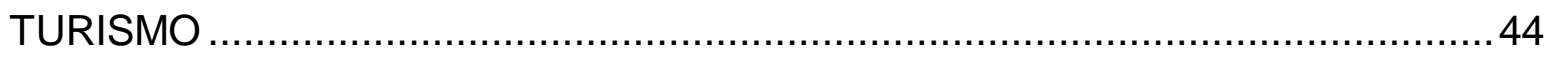

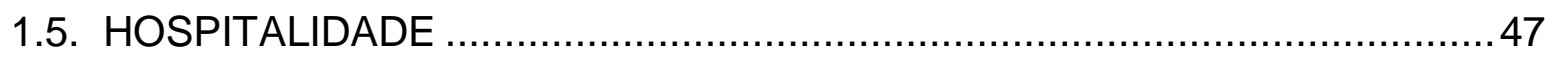

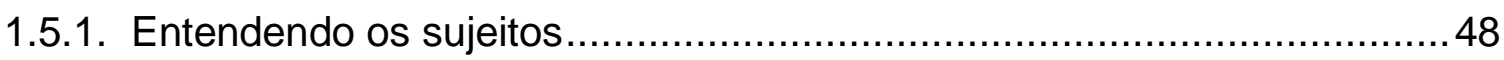

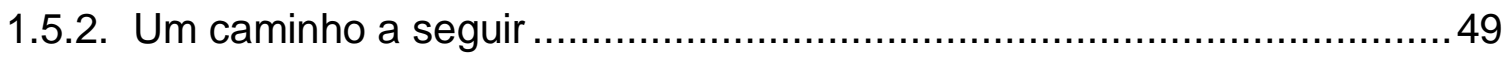

CAPÍTULO 2: DAS POLÍTICAS PÚBLICAS À CONSTRUÇÃO METODOLÓGICA.. 52

2.1. POLÍTICAS PÚBLICAS COMO INSTRUMENTO DE DECISÃO .53

2.1.1. Política Pública como processo de interação institucional e promoção do

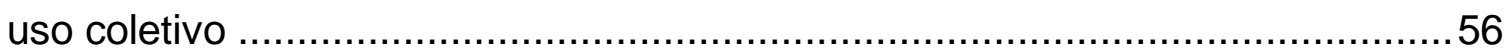

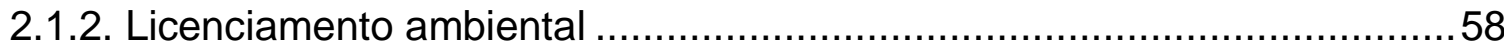

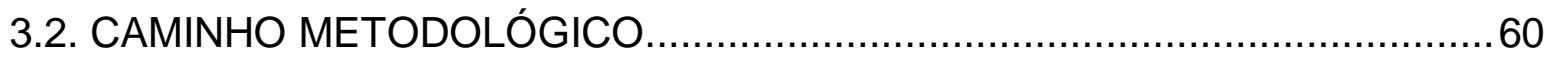

2.2.1. Instrumentos de análise e interpretação dos dados ..................................64

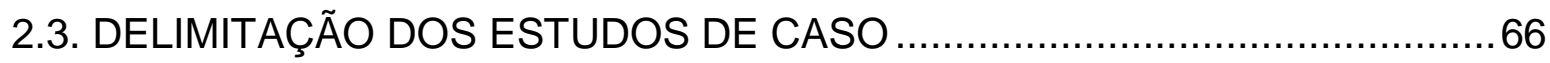

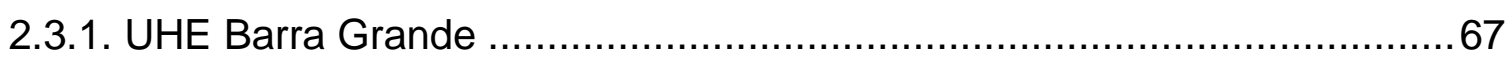


2.3.2. UHE Corumbá IV 74

CAPÍTULO 3: O PARADIGMA DA PRÁTICA DO TURISMO A PARTIR DAS POLÍTICAS PÚBLICAS 80

3.1. PANORAMA GERAL DOS DISCURSOS 80

3.2. ANÁLISE DO PROCESSO DECISÓRIO A PARTIR DA IDENTIFICAÇÃO DAS CRENÇAS .88

4.3 CONTRIBUIÇÕES DADAS PELOS PRINCIPAIS ATORES 97 CONSIDERAÇÕES FINAIS 102 REFERÊNCIAS 107 APÊNDICE 118 


\section{INTRODUÇÃO}

A pesquisa científica possibilita a investigação de problemas que limitam o avanço do conhecimento e a proposição de ações inovadoras. Nas ciências sociais as habilidades cognitivas dos sujeitos tornam-se subsídios essenciais no processo de planejamento e construção metodológica da pesquisa, pois será a partir destas orientações que serão traçados os caminhos que possibilitarão o entendimento das lacunas e a identificação das soluções para as questões de pesquisa.

O estudo das relações existentes no cotidiano humano permite ao pesquisador a revisão de teorias que ampliam suas percepções quanto à formação física, e psicológica, das comunidades e dos ambientes de uso coletivo. Portanto, as ações estabelecidas pelos atores coletivos necessariamente devem ultrapassar o convencional e visar um novo olhar global, no qual as necessidades e expectativas ganharão um papel dinâmico e passível de readequações.

Neste contexto, as cidades atravessam sucessivas transformações dentro de seus ciclos de vida, e tendem a passar por momentos de reordenamento, tanto territorial como espacial, onde a busca por novas estratégias produtivas possibilitam a (re)inserção da população ampliando sua qualidade de vida e despertando um novo olhar sobre o espaço de vivência e convivência.

Mediante a criação de novas preferências as políticas públicas e os programas governamentais são incrementados de forma a priorizar novas necessidades que, em alguns casos, se relacionam com a diminuição da desigualdade a partir da geração de emprego e renda, além da conservação das tradições a partir dos legados deixados.

No que tange as discussões relacionadas à água, observa-se a preocupação de reafirmar seu valor público e o direito de uso múltiplo enquanto elemento essencial à vida. Mas, nas últimas décadas a natureza tem alertado para os cuidados básicos para a continuidade desta disponibilidade. Frequentemente são veiculados na mídia casos de calor excessivo, seca, e falta 
de energia elétrica, o que demonstra a possibilidade de esgotamento temporário ou pelo menos redução das fontes.

A partir do segundo semestre de 2014, esse cenário tornou-se manchete de todos os jornais brasileiros, pois em função de questões ambientais os reservatórios utilizados para abastecimento e fornecimento de energia atingiram baixas históricas e tiveram parte de seu fornecimento suspenso ou interrompido temporariamente.

Diante da gravidade dos problemas gerados, as nações despertaram para a necessidade de incentivar boas práticas para a utilização dos recursos naturais, inicialmente priorizando a fauna e a flora, mas já remetendo ao desperdício da água. Neste caminho fundamentado na Política Nacional de Recursos Hídricos (Lei no 9.433/1997) e na Resolução aprovada pela Organização das Nações Unidas sobre o Decênio Internacional para a Ação 2005 - 2015: Água fonte de Vida, o Brasil estabeleceu, em 2005, pelo decreto de 22 de março de 2005, a "Década Brasileira da Água" cujos objetivos são:

(...) promover e intensificar a formulação e implantação de políticas, programas e projetos relativos ao gerenciamento e uso sustentável da água, em todos os níveis assim como assegurar a ampla participação e cooperação das comunidades voltadas ao alcance dos objetivos contemplados na Política Nacional de Recursos Hídricos ou estabelecidos em convenções, acordos e resoluções a que o Brasil tenha aderido. (BRASIL, 2005)

Desta forma, acreditou-se na evolução dos debates e das ações de forma a alcançar as metas estabelecidas pelo Fórum Mundial da Água que acontece trienalmente, e em 2015 acontecerá na Coreia do Sul. Para o ano de 2018 Brasília será a primeira cidade da América Latina a sediar o evento (ÁGUAS DO BRASIL, 2014)

Pensando na sustentabilidade e na perpetuação do recurso de forma continuada e múltipla, muitas são as políticas públicas que promovem 0 aproveitamento hidrelétrico do Brasil, principalmente pelas atividades afins que podem ser desenvolvidas tanto nos lagos quanto em seu entorno, a princípio sob o discurso do desenvolvimento econômico e social de localidades marginalizadas.

Nos projetos de construção de hidrelétricas estas questões ficam evidentes desde a etapa de sensibilização e mobilização da comunidade até 
especificamente os momentos das audiências públicas nas quais a população local tem poder de voto e, manifesta-se apontando suas expectativas a partir dos relatórios de inventariado e do plano de ação a ser executado durante a concessão dada ao consórcio responsável pela construção e gestão do reservatório artificial.

Na presente dissertação, cabe salientar que, inicialmente, foi proposto 0 estudo de três casos compreendendo empreendimentos de portes diferentes, ou seja, pequeno, médio e grande porte. Contudo, durante o levantamento documental, observou-se que até fevereiro de 2014 apenas dois Planos Ambientais de Conservação e Uso do Entorno de Reservatório Artificial PACUERA foram aprovados. Portanto, para o presente trabalho, foram consideradas as hidrelétricas Corumbá IV (GO) e Barra Grande (SC e RS) que se constituem nas duas únicas hidrelétricas que receberam o licenciamento pelo Instituto Brasileiro de meio Ambiente e de Recursos Naturais Renováveis IBAMA e que acataram as determinações da resolução do Conselho Nacional do Meio Ambiente - CONAMA 302/02 que estabelece as áreas de proteção permanente como de relevante interesse ambiental para o desenvolvimento sustentável, assim como sua interface com as águas já normatizadas pelo Código de Águas - Decreto Lei ㄲo 24.643/34.

Estas legislações, juntamente com a lei 9.433/97, que trata da criação da Política Nacional de Recursos Hídricos e do Sistema Nacional de Gerenciamento dos Recursos Hídricos, o Código Florestal, o Sistema Nacional de Unidades de Conservação - SNUC e o PACUERA, representam parte das políticas públicas vigentes que, de forma direta ou indireta, fazem menção ao uso do turismo enquanto fenômeno capaz de promover o desenvolvimento de regiões que sofreram com a ruptura de seu cotidiano, a partir da construção de hidrelétricas.

Dentro deste cenário propôs-se esta pesquisa como estudo de duas realidades estabelecidas e moldadas a partir das exigências legais de uso múltiplo da água enquanto bem público.

O estudo tem como reflexão o uso do turismo em áreas de barragens considerando as implicações que o tema traz às comunidades que se mantêm na região. Assim, busca-se responder se as políticas públicas do setor 
hidrelétrico estão contribuindo para o fomento das regiões amparadas pelo PACUERA.

Vale ressaltar, ainda, que no primeiro momento esperava-se avaliar a efetividade das ações propostas no PACUERA, visto que o Relatório é resultado da consolidação do interesse de todos os atores envolvidos e, a priori, atenderia às necessidades dos diferentes grupos de interesse - concessionários, governos, comunidades. Contudo, a partir da aplicação de pré-teste no IBAMA, foi necessária uma readequação do objeto uma vez que, apesar do Plano apontar ações que deverão ser desenvolvidas no reservatório e seu entorno, o órgão entende ser de sua competência apenas o monitoramento da APP - Área de Proteção Permanente.

Desta forma, como legalmente é necessário se estabelecer uso múltiplo apenas para as águas, até o momento não temos qualquer acompanhamento especifico dos projetos executivos que contemplam seu uso pelo turismo e lazer.

Portanto, nesta pesquisa utilizou-se, como estudo de caso, os Planos e demais documentos das Usinas Hidrelétricas Corumbá IV e Barra Grande, que apesar de implantadas em regiões diferentes, são as únicas com o PACUERA, também chamado de PCAU (Plano de Conservação Ambiental e Usos da Água e do Entorno do Reservatório) aprovados pelo IBAMA desde a publicação da Resolução CONAMA 302/02.

A Usina Hidrelétrica Corumbá IV está localizada no Estado de Goiás, entre os municípios de Abadiânia, Alexânia, Corumbá de Goiás, Gameleira de Goiás, Luziânia, Novo Gama, Santo Antônio do Descoberto e Silvania, sendo administrada pelo Grupo Corumbá Concessões. A área de seu reservatório corresponde a $173 \mathrm{~km}^{2}$ (quilômetro quadrado) com potência instalada de 129,6 MW (megawatts).

Já a Usina Hidrelétrica Barra Grande encontra-se entre os municípios de Anita Garibaldi/SC e Pinhal da Serra/RS totalizando $95 \mathrm{~km}^{2}$, com potência instalada de $708 \mathrm{MW}$. Sua concepção e gestão são feitas pela BAESA Energética Barra Grande S/A, resultado da parceria entre a Alcoa S/A, Camargo Correa Cimentos S/A, Companhia Brasileira de Alumínios, Companhia Brasileira de Força e Luz (Geração) e DME Energética Ltda. 


\section{OBJETIVO GERAL}

Analisar as políticas públicas que sugerem a prática do turismo em áreas de barragens de hidrelétricas.

\section{OBJETIVOS ESPECÍFICOS}

- Identificar as políticas públicas que dão suporte ao uso múltiplo das áreas de barragens;

- Analisar a coerência entre as ações propostas pelo Plano Ambiental e sua prática.

- Discutir as ações propostas para o uso do turismo nos reservatórios, tendo como prioridade os interesses manifestados pela população local durante o processo de construção do relatório.

\section{JUSTIFICATIVA}

A utilização de políticas públicas para organização e planejamento dos municípios permite aos atores a adequação de seus discursos de forma a moldar as alternativas de uso dos espaços públicos, assim como a delimitação das áreas privadas. Neste contexto, o turismo muitas vezes é apresentado como uma possibilidade estratégica de melhoria dos equipamentos de uso coletivo, como hospitais, praças, parques e estradas, além de proporcionar o desenvolvimento local a partir da ampliação do número de empregos e da criação de novos negócios.

De certa forma, o cenário desenhado pode refletir a realidade de algumas regiões. Contudo, é sabido que a padronização de modelos que desconsideram as intenções políticas e os interesses da comunidade residente, tendem a fracassar, comprometendo a estabilidade das cidades e frustrando as expectativas criadas nos empreendedores que, por acreditar na proposta, investem seus recursos sem conseguir resgatá-los após o fracasso da implantação do turismo. 
Estes dois aspectos despertaram o interesse em analisar como acontece o processo de inclusão do turismo em regiões atingidas por barragens, visto que, a partir de estudos anteriores (SILVA, 2009), foi identificado que existe a formalização deste interesse por parte das lideranças que participam ativamente do processo de aprovação dos Planos de Uso do Entorno do Reservatório Artificial (PACUERA/PCAU).

Justifica-se, ainda, a pesquisa, pelo interesse na melhor compreensão da interdisciplinaridade do turismo e responsabilidade socioeconômica, e pela curiosidade em compreender o papel das políticas públicas e suas nuances enquanto atos voltados para o bem-estar social e o desenvolvimento local.

Neste sentido, acredita-se contribuir para a discussão sobre a implantação efetiva do uso do turismo em áreas de barragens artificiais, independentemente de seu porte, como uma alternativa de desenvolvimento local. Isto, por acreditar-se que a atual legislação continua a servir apenas como muletas para os grupos responsáveis pela construção e distribuição de energia elétrica.

\section{QUESTÃO DE PESQUISA}

A relação institucional entre os ministérios é fundamental após o estabelecimento de novas regras, tanto por parte da Câmara Legislativa como, de forma endógena, por parte dos Conselhos e Agências reguladoras, que promovem alterações primordiais no que tange à preservação e a conservação do patrimônio natural, e muitas vezes possibilitam a mudança de postura gerencial das parcerias público privadas.

Uma vez que os lagos artificias, provenientes do represamento de rios para a construção de hidrelétricas, tornam-se potenciais atrativos turísticos, acredita-se ser fundamental apresentar como questão norteadora: Como ocorre a inclusão do turismo nas barganhas estabelecidas nos processos de construção das hidrelétricas amparadas pela resolução CONAMA 302/2002?

Para otimizar a discussão e possibilitar a escolha de instrumentos eficazes, fez-se necessário o desmembramento desta questão em perguntas 
direcionadas, que nortearam tanto a pesquisa de gabinete quanto a organização dos dados no texto final. Assim, sugere-se como questionamentos:

a) Que instrumentos constantes dos processos de licenciamento apresentam o tema turismo?

b) Como são apresentadas as ações de turismo para as hidrelétricas Corumbá IV e Barra Grande?

c) Existe alguma ressalva quanto ao período e à forma de implantação do turismo nos lagos artificiais das hidrelétricas em estudo?

d) Quais os atores envolvidos na construção e na implantação dos planos ambientais de uso do entorno do reservatório?

e) Quem possui poder de decisão no momento de estabelecer a ordem de execução do plano ambiental?

f) Em que momento surge a alternativa de turismo como uso múltiplo da água?

g) Quais as condições essenciais para a determinação do turismo como forma de desenvolvimento local?

A partir das repostas obtidas, como se verá ao longo da dissertação, observou-se que as políticas públicas do setor hidrelétrico estão bem estruturadas e convergem para o uso racional do meio ambiente, desde que este promova o desenvolvimento econômico. Em contrapartida, órgãos reguladores como o IBAMA têm atuado de forma incisiva, promovendo a mitigação dos efeitos nas áreas naturais e nas comunidades atingidas. Estas últimas desempenham papel secundário nos debates estabelecidos durante os processos de criação do Plano Ambiental, mas ainda assim recebendo voz nas audiências públicas, de forma a sensibilizar o Ministério Público para a intervenção em seu favor, garantindo, pelo menos, os pagamentos das indenizações.

Visando atender à questão de pesquisa desta dissertação, cumprindo com os objetivos delimitados, acredita-se ser relevante a organização deste trabalho a partir do Capítulo 1, que se ocupou de apresentar a aproximação teórica com os conceitos de uso do espaço, turismo e lazer, assim como das 
práticas de atividades em áreas naturais. Desta forma, espera-se possibilitar ao leitor a compreensão do universo que circunda as discussões sobre 0 desenvolvimento sustentável.

A partir do segundo capítulo, priorizou-se a compreensão das políticas públicas e dos caminhos metodológicos escolhidos para tratar a problemática em questão. Assim, além da construção dialógica do tema, optou-se pela rápida caracterização dos espaços em estudo, no caso a Usina Hidrelétrica (UHE) de Barra Grande e a UHE Corumbá IV.

Por fim, estruturou-se no Capítulo 3 os resultados alcançados a partir das pesquisas de gabinete, e a análise e interpretação de documentos, reportagens e entrevistas, todas relacionadas inicialmente à construção de hidrelétricas, tendo como foco a temática do turismo como ferramenta para o desenvolvimento socioeconômico. 


\section{CAPÍTULO 1: BREVE DISCUSSÃO TEÓRICA SOBRE TURISMO E LAZER}

A construção de conceitos nas ciências sociais aplicadas perpassa a interposição de saberes e promove o distanciamento entre o diálogo teórico e a prática. Isto em função das estratégias de pesquisa que se aproximam da subjetividade do pesquisador na escolha de seus instrumentos de trabalho, e pela postura adotada tanto pelo mercado quanto pelos tomadores de decisão ao estabelecerem políticas ainda distantes da realidade das destinações. Criam-se abismos na interlocução dos atores responsáveis pela integração e implantação das atividades e ações que compõem a organização e planejamento estratégico das cidades e estados.

No estudo do turismo, muitas vezes, nos deparamos com estes vazios onde os atores públicos e privados não conseguem administrar suas competências. Ora estão preocupados em atribuir funções técnicas, ao invés de acompanhar ativamente os processos, ora em estabelecer discursos sem 0 cuidado de aprofundar-se sobre as temáticas em debate.

Desta forma, a gestão dos espaços e das atividades ocorre a partir de interesses individuais, não respeitando a necessidade de recursos humanos com conhecimentos adequados acerca do fenômeno turístico e de suas políticas públicas. Por sua vez, a comunidade local nem sempre identifica e aproveita as oportunidades de atuar ativamente no processo de planejamento e organização de seu município, tornando-se elemento marginal no processo de desenvolvimento regional.

Esta lacuna, deixada na discussão dos processos que envolvem a escolha do turismo como oportunidade de melhoria para as cidades, se depara com a importância do compartilhamento dos espaços públicos e privados, tanto pelos residentes quanto pelo turista pois, de forma abrangente, ambos têm a oportunidade de desfrutar dos atrativos para a prática do lazer e para a "descoberta" do turismo. 
O entendimento dado às questões de pertencimento também deve ser avaliado a partir da compreensão do que vem a ser o espaço de vivência e de convivência, e de como se dá a sua construção sem a ruptura com os aspectos socioculturais pré-existentes. Esta preocupação espacial tangencia as questões abordadas por Sachs (2009), ao dissertar sobre os caminhos para o desenvolvimento sustentável, principalmente sobre os critérios para a construção de um ambiente sustentável sob o ponto de vista territorial, ecológico, ambiental, social, econômico, cultural e político-institucional.

A partir desta visão global do espaço, introduzem-se no debate as questões relacionadas ao uso múltiplo dos ambientes, fazendo-se necessária uma releitura de como os fenômenos do turismo e do lazer se dão dentro da rotina das destinações, visando à construção coletiva da qualidade de vida, e minimizando os conflitos culturais advindos das particularidades dos indivíduos. Dessa forma, ao longo desse capítulo serão introduzidos conceitos e discussões acerca das teorias existentes.

Seguindo nesta perspectiva, acredita-se ser relevante a abordagem dos temas referentes ao convívio desses grupos de interesse, também a partir dos benefícios diretos gerados, como por exemplo pelas políticas públicas que são, em parte, estabelecidas pelos Ministérios do Turismo e do Esporte. Uma vez que são frequentes as pautas interdisciplinares nas quais as decisões tomadas norteiam o desenvolvimento local a partir de temáticas afins, sob as quais se identifica 0 interesse de outros Ministérios como o do Meio Ambiente, Planejamento, Cultura, Cidades, dentre outros.

Questiona-se a respeito de qual seria a forma eficiente e coerente de se abordar as temáticas sem recorrer ao reducionismo desqualificando a relação entre teoria e prática, o que proporcionaria a incompletude do processo que necessita ser analisado a partir do pleito da coletividade. Além disso, como são apresentadas à sociedade ações que promovam a melhoria dos espaços comuns e da qualidade de vida a partir do desenvolvimento de ações de lazer e turismo? Como o turismo e o lazer poderão contribuir para a interação consciente do homem com a natureza?

Essas inquietações nortearão a discussão analítica dos conceitos pertinentes à temática deste trabalho, possibilitando a construção da base 
teórica de interpretação dos dados da pesquisa e dos prognósticos estabelecidos. Cabe ressaltar que este capítulo não tem como foco apontar propostas de organização conjunta para o turismo e o lazer, tampouco uma leitura epistemológica sobre os conceitos e as categorias pré-estabelecidas por estudiosos da área.

Em síntese, para a construção deste capítulo é apresentada a contextualização de como pode ser entendido o espaço e suas interações, de forma a atender a dinâmica do turismo e do lazer em áreas naturais que margeiam reservatórios artificiais das usinas hidrelétricas. E, as relações humanas criadas a partir do encontro entre os sujeitos locais e os visitantes, sem comprometer a dinâmica da sustentabilidade que deve ser considerada como requisito básico para o planejamento das cidades.

\subsection{O ESPAÇO COMO RESULTADO DAS INTERAÇÕES}

As relações existentes no cotidiano das pessoas impactam diretamente na construção de suas percepções do tempo e do espaço, principalmente para a compreensão de sua dinâmica e da construção de cenários e paisagens. Estes elementos devem ser interpretados pelos gestores e planejadores como condições básicas para a organização e discussão do uso dos ambientes, de forma consciente e racional. Por outro lado, devem ser visualizados pelos residentes e turistas como uma oportunidade de melhoria da qualidade de vida e do bem-estar, ou seja, como oportunidade de interação com a diversidade.

Ferreira (2012) menciona esse intercâmbio ao apresentar o turismo como oportunidade de promoção e apropriação dos ambientes que também atendem às demandas da comunidade local no cotidiano das cidades. $O$ autor destaca a relevância da ampliação do uso múltiplo dos espaços a partir das intervenções conscientes promovidas pelos setores público e privado ao longo da implantação das estratégias previstas para os reservatórios de hidrelétricas.

Mas, o que seria este espaço? Muitos geógrafos trabalham esta delimitação considerando premissas isoladas, que tendem a restringir o real significado do termo. Contudo, outros já repensaram seu posicionamento e adotam interpretações mais abrangentes. Dentre estes últimos destaca-se Milton 
Santos (2008) que delimita o conceito de espaço como um elo composto pela interação entre os elementos geográficos que determinam a constituição territorial e a sociedade que habita estes lugares. Assim, deve-se compreender que o espaço reflete uma construção mais ampla onde o cotidiano sofre, frequentemente, alterações em função da dinâmica social.

Uma vez que o sujeito torna-se protagonista do processo de produção do espaço, a compreensão de seu papel enquanto agente político "necessita da sociedade civil para invocar significados, articulações, exclusões”, “(...) e do Estado, para legitimar diante do todo e contribuir para a organização da divisão social" (Toro, 2005, p.51). Esse discurso permite a inclusão do poder público e de suas competências relacionadas à busca do bem-estar social e da normatização das relações de forma a atender as inquietações geradas pelo uso e ocupação das cidades por indivíduos com pertencimentos distintos. Esses atores, caracterizados até o presente, suscitam a introdução de novas questões que são pressupostos básicos do diálogo entre sociedade e Estado, no que se refere à compreensão do espaço como "conjunto de lugares compreendidos como porções do espaço produtivo e de consumo" (SAQUET, 2008, p.34).

Desta forma, para a identificação do cenário no qual a interação entre indivíduos e a partir da delimitação de um "lugar físico" são agentes transformadores da realidade, cabe o entendimento proposto por Saquet (2008) sobre território enquanto jogo de poder, onde as delimitações seguem a dinâmica histórica e a diversidade das relações sociais, ou seja, estabelece-se uma relação complexa de interação. Em síntese:

(...) o território pode ser considerado como delimitado, construído e desconstruído por relações de poder que envolvem uma gama muito grande de atores que territorializam suas ações com o passar do tempo. (SAQUET, 2008 p.31)

A partir desta construção inicial novas provocações surgem, pois não é possível pensar em sociedade sem avaliar a questão do capitalismo, já que as relações estabelecidas entre as comunidades são baseadas nas relações de consumo e nos benefícios e malefícios que estas poderão gerar para as futuras gerações. Consequentemente amplia-se este olhar para a urbanização e todos os desmembramentos gerados a partir das cidades. 
Uma vez que já se estabeleceu a relevância do espaço, do sujeito social, do poder público e do território dentro do universo de interpretação das relações cotidianas, acredita-se ser essencial dentro da dinâmica cotidiana, a inclusão dos aspectos econômicos que determinam a complexidade existente nos processos de interação destes atores.

Portanto, é fundamental entender que a rotina dos centros urbanos exige uma atuação diferenciada que, segundo Harvey (2001), pressupõe uma atuação mais coordenada a partir do estabelecimento de novas estruturas e padrões ecológicos, podendo, desta forma, afetar no comportamento das relações de consumo e de poder. Estas duas dimensões representam de forma simbólica parte significativa das necessidades individuais e coletivas das pessoas que desfrutam de lugares comuns, tendo como motivação e expectativas elementos divergentes ou pelo menos não convergentes ao ponto de serem declarados.

Neste contexto, o turismo pode ser compreendido como fomentador de alterações, muitas vezes pouco favoráveis à perpetuação dos lugares enquanto ambientes de vivência e convivência. Isso ocorre uma vez que ainda não existe coerência entre as ações estabelecidas pelas instâncias de governança local, regional e federal. Esta falta de coesão por sua vez permite a utilização predatória e irresponsável dos destinos, eternizando o duelo entre as insatisfações dos residentes e as necessidades dos turistas.

Carmo (2014) aborda a temática da governança territorial destacando os elementos fundamentais à sua determinação enquanto processo de construção das políticas públicas dentro de espaços estabelecidos e a partir das contribuições dos atores, ou seja, considerando o debate a partir de questões complexas.

Expostos os tópicos teóricos registramos que o processo de
governança territorial diz respeito um conjunto de atores e a um espaço
de concretização do objeto do debate e da deliberação e decisão
destes, um espaço socioeconômico contextualizado pelo território nas
suas múltiplas dimensões: geográficas; físico-ambientais;
socioculturais; econômicas; administrativas e organizativas. (CARMO,
2014, p.44-45)

Evidencia-se a complexidade existente nas discussões sobre a temática territorial, consequentemente aos usos dados ao espaço visto que os conflitos de interesse permitirão a sobreposição de opiniões em diversas esferas. Para o 
turismo este cenário pré-determinado é utilizado frequentemente como pano de fundo para os debates que envolvem a utilização de espaços públicos por atores públicos, privados, comunidade local e turistas/visitantes. Portanto, para 0 presente contexto cabe a reflexão apresentada por Souza e Kushano (2013) sobre o espaço turístico:

Quanto ao espaço onde ocorre o fenômeno turístico, é um espaço
complexo, com inúmeras possibilidades de interpretação e que do
ponto de vista físico e estrutural, reflete de alguma forma o modo com
que as cidades se preparam para o fenômeno social denominado
turismo, espaço em que acontecem as variadas relações entre os
atores sociais que se envolvem neste fenômeno. (SOUZA e
KUSHANO, 2013 p.329)

A interação entre estes atores exige a construção do que se espera com o turismo e quais as suas contribuições, visto que o espaço de uso sofrerá interferências que em condições de pouco acompanhamento poderão converterse em deformidades quando comparadas ao cenário inicial. Portanto, faz-se necessário introduzir nesta discussão o debate sobre a sustentabilidade enquanto instrumento presente nas políticas públicas de turismo e no cotidiano dos envolvidos na dinâmica turística.

Ao analisar a historicidade das políticas públicas de turismo destaca-se que desde a década de 1960 existem traços que podem ser associados à sustentabilidade de forma implícita, em parte por trazerem concepções voltadas à proteção ao patrimônio natural e cultural, em outros momentos por se remeterem a questões focadas na preservação/conservação (BORGES, 2013). A partir da década de 1990 destaca-se a atuação federal na apresentação da sustentabilidade de forma explícita, pautada nos pilares econômicos e ambientais, considerando as proposições discutidas na Eco $92^{1}$, principalmente no que tange ao desenvolvimento regional e o turismo orientado para a natureza. A partir de 2003, com a criação do Ministério do Turismo, o termo perdurou muitas vezes de forma indiscriminada e sem clareza, frequentemente associado à racionalidade ambiental, ao equilíbrio e ao turismo ecológico.

Este retrato estabelecido por Borges (2013) demonstra a importância dada pelo governo federal à sustentabilidade. Contudo, reforça a importância da

\footnotetext{
${ }^{1}$ Conferência das Nações Unidas sobre o Meio Ambiente e Desenvolvimento realizada no Rio de Janeiro (RJ) entre os dias 3 e 14 de junho.
} 
ampliação da discussão desta temática, visto a pouca clareza existente nos discursos. Portanto, traz-se a discussão as considerações de Veiga (2010) ao reforçar a importância do desenvolvimento sustentável enquanto um processo qualitativo de produção coletiva onde cabe aos sujeitos escolher os caminhos a seguir, seja priorizando seu bem-estar, a economia ou o meio ambiente. Para o presente estudo, essas exposições ampliam o entendimento do território enquanto ambiente de tomada de decisão, de morada e de visitação, ou seja, espaço de múltiplo uso.

Como as relações estabelecidas necessariamente possibilitam a falta de harmonia entre os indivíduos e, em alguns casos, entre os poderes, acredita-se na necessidade de estabelecer parâmetros objetivando o uso racional do meio ambiente para minimizar os impactos indesejados e propor a construção de um entendimento com base nos pilares da sustentabilidade. Para Leff (2010):

\begin{abstract}
As práticas produtivas, dependentes do meio ambiente e da estrutura social das diferentes culturas geram formas de percepção e técnicas específicas para a apropriação social da natureza e da transformação do meio. Mas ao mesmo tempo a capacidade simbólica do homem possibilitou a construção de relações abstratas entre os entes que conhece. Desta forma, o desenvolvimento do conhecimento teórico acompanha seus saberes práticos. (LEFF, 2010, p.23)
\end{abstract}

Neste contexto fica evidente a relação de dependência entre a compreensão do espaço e de sua dinâmica, principalmente por envolver questões prioritárias para o desenvolvimento social e a escolha de ações estratégicas para o desenvolvimento econômico.

Para esta dissertação estes elementos tornam-se fundamentais, uma vez que a ambiguidade das políticas públicas referentes aos entornos dos reservatórios artificiais que, apesar de apresentarem legislação própria estabelecida pelo Conselho Nacional de Meio Ambiente - CONAMA estão desamparadas, já que para os órgãos competentes o entorno é reduzido às áreas de proteção permanente, ou seja, a uma pequena faixa de terra onde a prioridade é a preservação da biodiversidade. No entanto, para receber as licenças ambientais, é exigido um levantamento pragmático não apenas da fauna e flora, mas também do potencial turístico desse espaço.

Nessa perspectiva acredita-se que a despeito da regulamentação proposta pela Resolução CONAMA 302 de 20 de março de 2002, iniciar seu 
texto limitando o entorno do reservatório à área de proteção permanente, ainda assim seria possível uma nova interpretação baseada no artigo $4^{\circ} \S^{4}$ onde se estabelece que o uso pelo turismo e pelo lazer não pode ultrapassar $10 \%$ da área total do entorno do reservatório.

Esta discussão será retomada ao longo desta dissertação, visando o esclarecimento dos temas correlatos, assim como das oportunidades de ações de intervenção nos espaços atingidos por barragens de forma a reduzir os impactos negativos e promover a melhoria da qualidade de vida das comunidades residentes, utilizando como ferramenta o turismo.

\subsection{UM OLHAR SOBRE O TURISMO E SUAS RELAÇÕES COM O MEIO}

As discussões para o que se entende como o estabelecimento de uma Ciência do Turismo, assim como sua definição, ainda passam por variações em função das particularidades das pesquisas e do olhar do pesquisador. Neste sentido, Panosso (2005) ressalta a existência de três perfis de pesquisador: 0 que acredita na cientificidade do turismo; o que ainda vê com cautela o processo de sua construção científica e o que não vê a possibilidade de se ter uma ciência do turismo e o reduz a uma atividade humana.

Quanto à historicidade da atividade, tradicionalmente é ensinado nos Cursos de Graduação em Turismo que não existe consenso para o registro de quando se iniciou o turismo no mundo. Para alguns, a atividade existe desde os templos bíblicos, para outros a partir das viagens de Thomas Cook em 1878. Todavia, esta dúvida talvez devesse ser substituída por uma questão que realmente importa dentro do entendimento do turismo, qual seja, "como teorizar sobre o turismo sem que o recorte prejudique sua essência, uma vez que pode ser abordado como prática, como atividade, ou mesmo, como fenômeno?"

Neste sentido, o entendimento de que as interferências das outras áreas de conhecimento não podem ser estudadas de forma segmentada é fundamental, pois permite melhor compreensão das relações e dos impactos independentemente de sua natureza. Apesar desta concepção, ainda existem muitos teóricos que tendem a olhar a "ciência" a partir de uma única faceta ou a 
partir das necessidades dos sujeitos sem que estes se relacionem ao local visitado, ou ao longo do deslocamento.

No presente trabalho buscou-se a definição conceitual a partir da economia, posteriormente a geografia, a sociologia, a psicologia, o marketing, dentre outros.

Por questões diversas tendemos a relacionar o turismo com algo econômico, capaz de ser mensurado por meio de diagnósticos que apresentam fluxo de pessoas e divisas, levando em conta apenas a criação de estimativas e estratégias. Esta visão é adotada pelo Ministério do Turismo que segue a Organização Mundial do Turismo (OMT) em sua abordagem mais difundida: O turismo compreende as atividades desenvolvidas por pessoas ao
longo de viagens e estadas em locais situados fora de seu
enquadramento habitual por um período consecutivo que não
ultrapasse um ano, para fins recreativos, negócios e outros (OMT,
1994, p.11).

O reducionismo observado neste conceito deve-se principalmente ao contexto histórico mundial, onde grandes metrópoles atingidas pela Segunda Guerra estão novamente no topo da economia e países do Terceiro Mundo começam a enxergar a possibilidade de desenvolvimento a partir do incremento ao turismo. Neste sentido, a demonstração de milagres econômicos a partir de pouco investimento torna-se um grande atrativo para discussões políticas e tomadas de decisão de forma rápida e sem planejamento.

Além disto, o conceito também pode ser considerado inconsistente por abordar questões de deslocamento e tempo sem o comprometimento de incluir as interações que acontecem ao longo das viagens.

A OMT, enquanto referência mundial, ainda comete falhas ao se preocupar com a categorização dos atores do turismo de forma isolada sem orientação para um trabalho mais comprometido, pois em seus estudos mais recentes apresenta a atividade com uma indústria, ou seja, abordando apenas o mercado e suas nuances. Contudo, é possível notar um pequeno movimento da Organização em direção a outras formas de olhar o turismo quando, em seu sítio oficial, são abordadas questões que o relacionam com o clima, a redução da pobreza e o desenvolvimento sustentável. 
Com o passar dos anos muito se pesquisou sobre a conceituação epistemológica do turismo, o que prejudicou sua consolidação como ciência tanto dentro da academia quanto no mercado. Desta forma observa-se que a falha encontrada na teorização da OMT se repetia em muitos trabalhos como os de MCINTOSH (2002) e COOPER (1998), organizadores de manuais introdutórios, cujo trabalho, no entanto, certamente contribuiu, no devido momento, para o entendimento e sistematização dos conceitos existentes.

Neste sentido, a principal crítica de Moesch (2004) deve-se à visão de teóricos a partir das ações dos turistas somente como contribuições positivas, na medida em que cooperam para o desenvolvimento local certificados por estudos estatísticos. Para a autora, uma vez que o turismo é uma combinação complexa de relacionamentos entre produção e serviços, cabe entendê-lo como fenômeno que compreende práticas sociais, ambientes diversos e trocas interculturais, tudo isto mantendo as características dinâmicas do sujeito enquanto agente.

Por mais que se tente conceituar o fenômeno turístico, sabe-se da necessidade de sempre se garantir um novo olhar sobre a teoria, pois por envolver atores com características singulares sempre exigirá uma releitura a partir das novas condições criadas. Assim, um novo questionamento surge e passa a ser relevante no que se refere a qual foco deverá ser utilizado na construção do saber turístico.

Diante de tais questionamentos e ao contrário do que se poderia esperar, ainda hoje se observa a visão distorcida do turismo em função de sua análise facetada, ou seja, sempre considerando o recorte que melhor se adapta ao segmento em estudo.

Os pesquisadores em turismo têm avançado nas discussões sobre a temática $e$, com isso, ao refletir sobre os cenários que envolve 0 desenvolvimento do turismo no mundo conseguem identificar momentos de sobreposição de interesses que transformam a compreensão do todo como uma parte importante, mas respondendo a poucas inquietações.

Ao publicar o artigo El turismo como disciplina científica, Jafari (2005) apresenta uma síntese das discussões sobre a indústria do turismo, já 
vislumbrando seu avanço para um fenômeno sociopolítico em processo de construção. $O$ autor acredita que ao longo dos anos o turismo superou as interpretações economicistas, impactantes no sentido de não trazer fortes contribuições econômicas e de possibilitar outros impactos sociais e ambientais, a visão alternativa e por último sua vertente interdisciplinar que alia questões técnicas e operacionais. Cabe ressaltar que Jafari vislumbra a criação de uma quinta etapa sob a qual o comportamento político será elemento chave para a discussão.

O que se percebe até o momento é que por ser um mosaico de muitas disciplinas o turismo precisa ser entendido como um todo, onde outras áreas apresentam contribuições significativas em seu estudo, pois, quando analisadas individualmente, impossibilitam seu entendimento de forma integral que contemple todos os seus vértices.

Panosso (2005) sugere a compreensão do turismo com base no entendimento das experiências vivenciadas e suas contribuições para a construção do "ser", uma vez que é a partir deste círculo de transformações que o desejo de conhecer se ampliará e motivará novas viagens. Por mais que esta proposta de construção do conhecimento do turismo, compreendendo suas relações, apresente algum avanço, ainda assim é preciso cautela ao considerar as definições do autor, pois se atêm às questões filosóficas do indivíduo sem a intenção de contribuir para a compreensão do planejamento das regiões e os impactos que ocorrem a partir das interações dos atores.

Molina $(2001 ; 2005)$ aponta a visão simplista adotada na América Latina na qual as questões relacionadas ao turismo estão associadas ao desenvolvimento e suas implicações favoráveis à economia, demonstrando a possibilidade de reverter seus impactos negativos a partir da construção de um novo olhar a partir de sua essência enquanto dimensão do espaço temporal subjugado ao tempo livre. Desta forma, apresenta as possíveis facetas do indivíduo que em função do desenvolvimento econômico conquistou novos benefícios e aprendeu a desfrutar do descanso para se recuperar e repor suas energias para nova jornada.

Já Krippendorf (2001), ao propor a compreensão do turismo a partir da análise dos turistas e dos autóctones, rompe com o imperialismo do 
economicismo que até o momento era entendido como essencial. Além disto, inicia os debates quanto aos aspectos negativos dos impactos gerados pela prática do turismo. As contribuições do autor, quando associadas às de Molina, reforçam a importância de relacionar o turismo ao lazer e ao tempo livre.

Em uma contribuição mais recente Moesch (2004) destaca que o saber do turismo é parte do pós-modernismo ao comportar-se como uma amálgama onde tempo, espaço, diversão, economia, imaginário, comunicação e ideologia se relacionam. Isto a partir de uma combinação complexa e não linear. Apesar de não negar a importância econômica do fenômeno, direciona seu olhar para as relações humanas e suas práticas histórico-sociais.

1.2.1. Teoria dos sistemas como ferramenta para entendimento do fenômeno turístico

Dentre os teóricos que trabalham com o turismo, muitos optam por definilo a partir de abordagens metodológicas, ou seja, que além do pensamento teórico, possibilitam a aplicação de modelos. Na literatura sobre o turismo os modelos mais recorrentes baseiam-se na Teoria Geral dos Sistemas.

A Teoria Geral dos Sistemas, proposta por Ludwig von Bertalanffy em 1973, foi pautada em fórmulas matemáticas de maneira a atender as inquietações de sua área de conhecimento, a Biologia. Para o autor, a análise das partes contribui para a compreensão do todo. Contudo, é fundamental que se considere que o somatório destas partes jamais corresponderá ao todo. Para ele, a Teoria Geral possibilita o estudo da totalidade visando a formulação de princípios válidos para os sistemas em geral, não somente os biológicos, independendo da natureza ou das forças que atuam nos elementos. Os sistemas são complexos de elementos em interação.

Uma vez que a Teoria propõe a compreensão das relações entre as partes para o entendimento do conjunto, tornou-se comum sua utilização em diversas áreas do conhecimento científico (BERTALANFFY, 2012).

Dentro deste contexto, a proposta de Bertalanffy foi incorporada ao turismo que passou a ser tratado como um sistema aberto, constituído a partir 
do fluxo contínuo de entradas e saídas, conservando-se mediante a construção e desconstrução dos componentes. Todavia, nas ciências humanas a aplicação desta teoria apresenta limitações, pois não aborda questões relacionadas ao comportamento do indivíduo, sua trajetória e cultura.

Apesar de Bertalanffy (2012) ter estruturado seu trabalho considerando como objeto uma realidade das ciências naturais, ainda assim os cientistas sociais conseguiram transportar suas ideias para diferentes áreas de conhecimento. Especificamente o turismo observa um volume considerável de publicações nesta temática, sendo os autores de maior relevância Mario Beni, Neal Leiper, Jost Krippendorf, Pierre Lainé, Sergio Molina e outros.

Para Sessa (1983) o turismo está associado à relação de três semiagregados: oferta turística, infraestrutura de base e superestrutura turística, sendo esta última o único elemento possível de ser entendido como indústria em seu sentido estrito. Ao agregar novos atrativos e atividades o turismo passa a gerar divisas de forma direta, aumentando sua interdependência estrutural. Quanto à contribuição sobre as relações estabelecidas destaca-se o comportamento do turista ao ter a oportunidade de ir ao encontro do produto dentro do ambiente no qual ele é "produzido", proporcionando aos locais o desenvolvimento a partir das viagens internacionais de indivíduos de países de primeiro mundo a outros menos desenvolvidos (SESSA, 1983).

Apesar de avançar a discussão, ao se preocupar com a troca de experiências entre turistas e locais, a interpretação do autor remete a um novo momento de colonização, onde as colônias ao invés de contribuírem ofertando riquezas, passam a receber dos colonizadores divisas para se organizar e acelerar seu crescimento. Quanto aos aspectos estruturais do sistema proposto por Sessa, destaca-se a preocupação indireta com a dinâmica do turismo, o que requer um rearranjo constante da oferta. Neste sentido o autor reafirma a postura de teóricos que até a década de 1960 priorizavam o aspecto econômico em detrimento dos demais.

Pimentel et al. (2014) priorizam a necessidade dos sistemas atenderem às exigências funcionais, pois assim torna-se possível a compreensão das relações existentes entre o ambiente e os elementos do sistema e como se 
influenciam mutuamente. Para estes autores, as questões operacionais também devem ser consideradas, porém não como pertencentes a um sistema autopoiético, pois não se autorreferenciam, mas sim como determinantes das operações e da sequência de execução.

Beni (2003), em sua obra "Análise Estrutural do Turismo", prioriza a revisão de conceitos elementares envolvidos no planejamento turístico e apresenta modelos para dinamizar o entendimento desta ciência em construção a partir de seus subsistemas. Assim, o Sistema Turístico (Sistur) propõe a análise dos ambientes ecológico, social, econômico e cultural como subsistemas, cada um delimitado em seus campos de atuação. Os componentes do Sistur, portanto, são os quatro ambientes, a superestrutura, a infraestrutura, o mercado, a oferta, a demanda, a distribuição e o consumo (BENI, 1990; 2003).

O trabalho de Beni tornou-se ferramenta muito utilizada no planejamento turístico, em função da delimitação da dinâmica proposta pelo sistema. Uma das limitações deste trabalho está na visão do fenômeno como um "produto" com características meramente estruturais sem permitir as intervenções ocasionadas pelas relações entre os sujeitos e seus impactos, não levando em conta o que havia sido proposto por Sessa. Neste sentido, reforça-se a necessidade de se planejar o turismo não apenas a partir das demandas do turista, mas como parte integrante de um sistema complexo em que as estruturas deveriam ser pensadas para atender os moradores locais e, por consequência utilizadas pelos visitantes.

Anjos (2014) destaca a importância de os subsistemas turísticos se integrarem ao sistema local e ao geral para, desta forma, alcançar as necessidades estabelecidas pelos sistemas organizados a partir dos espaços urbanos. Talvez esta não seja uma análise especificamente do turismo, mas acredita-se que em muito se relaciona à discussão por incitar o olhar do gestor para a superação das fronteiras geográficas estabelecidas, mas que não atende à dinâmica da prática do turismo.

A proposta de Leiper (1979) apresenta um modelo sistêmico sintético onde qualquer dos componentes pode ser tomado como foco, tornando-se o ator prioritário a ser desvelado. Segundo o autor, a composição desse modelo se dá a partir dos seguintes elementos: pelo menos um turista, região de origem, rota 
de trânsito, região de destino e área de atuação da indústria do turismo. Embora Leiper não tenha identificado um conceito que atenda de forma integral às necessidades do turismo, ele o caracterizou como um sistema que envolve uma viagem temporária, fora do local habitual de moradia, por pelo menos uma noite e sem objetivos remunerados.

Neste sentido, Martínez (2006) destaca, como limitação da teoria proposta por Leiper, a ausência de áreas para atuação das disciplinas que também são facetas importantes para a compreensão das ações envolvidas durante a prática turística. Além das restrições apresentadas, o modelo de Leiper empobrece o entendimento científico ao abordar o fenômeno como indústria, conceito pouco aceito por propor um recorte dentro da atividade, restringindo-a a um mix de oferta e demanda onde o imaginário e as relações sequer são suscitados.

Enquanto Leiper propõe o sistema turístico pautado em suas condições estruturais, Lainé (1984) pauta suas considerações a partir dos movimentos de ida e de volta, onde cada elemento é ponto de partida para interações capazes de promover influências transformadoras. A partir destes movimentos espera-se a observação sincrônica e dinâmica para identificação do equilíbrio num certo nível de organização.

Para o autor, a teoria dos sistemas pode ser utilizada como ferramenta para a pesquisa que deve considerar a relação turística como composta por pelo menos três sistemas: emissor, receptor e turístico de base.

De acordo com Martínez (2006), o objetivo dos sistemas turísticos é proporcionar aos turistas, sujeitos dinâmicos, condições adequadas para deixar seu ambiente habitual e buscar novas experiências. Dentro das perspectivas dos locais visitados espera-se a melhoria das condições de vida dos habitantes gerando efeitos multiplicadores. Desta forma, este complexo de relações está envolto por uma escala hierárquica composta de: subsistema básico, sistema, super e hipersistema.

Dentro da demarcação de limites e fronteiras, Martinez destaca os atrativos, transporte, oferta turística, política migratória, política sobre meio ambiente, política de transporte, política econômica, localização geográfica, compartilhamento dos recursos naturais e culturais comuns, interesses 
econômicos/comercias e compartilhamento de afinidades políticas e culturais. Este campo de pensamento, por abranger a compreensão do sistema como algo vasto, podendo ser composto por um espaço geográfico amplo, exige uma atenção maior quanto às particularidades regionais que envolvem não apenas o país visitado, mas também o de origem.

Um ponto de destaque na abordagem sistêmica de Martínez deve-se à relevância dada à comunicação, a partir da qual torna-se possível o movimento circular proposto por Bertalanffy onde são percebidas as entropias e a retroação do sistema. De acordo com o autor:

\begin{abstract}
No turismo a informação é essencial para todos os processos referentes à condição regular do turista, que tem informação que recebeu de diversos meios. Quando chega à localidade o turista começa um processo de observação que valida ou invalida a informação que possui. A partir de então tem início um processo de retroalimentação, positiva ou negativa, conforme a avaliação feita do destino depois desta confrontação. (MARTíNEZ, 2006 p.130)
\end{abstract}

De forma indireta, Krippendorf (2001) apresenta em sua obra "Sociologia do Turismo" uma proposta de sistema tendo como componentes, em primeiro plano, os interesses dos moradores locais e dos turistas, os objetivos e expectativas do setor privado, centros turísticos, prestadores de serviços, profissionais da área e, por fim, os interesses dos que atuam de forma fortuita.

A abordagem do autor por mais sintética que seja no que tange à descrição de um modelo estrutural, sem dúvida proporcionou um avanço científico, pois colocou em foco os impactos sofridos pelos atores ao passo que o foco passa a ser o ser humano e seus interesses, mesmo que estes sejam descontínuos e incompatíveis. Alerta quanto à importância de se pensar o turismo de forma sensata sem o associar a uma tábua de salvação.

Molina (2005) ressalta que o turismo enquanto sistema está integrado por um conjunto de subsistemas (superestrutura, demanda, infraestrutura, atrativos e equipamentos) que se relacionam para alcançar um objetivo comum que vai desde a evolução dos indivíduos, por meio do descanso e diversão, até o desenvolvimento econômico e social. Contudo, este autor usa a terminologia indústria do turismo afirmando que na prática da atividade consumimos os recursos naturais combinados com outros insumos, contrariando o entendimento 
do fenômeno turístico e, ao mesmo tempo, ignorando o ser humano enquanto ator social. Ainda assim, entende-se que seu modelo sistêmico permite a evolução dentro das demais teorias ao propor a inclusão do poder público, suas políticas e programas como partes da superestrutura.

No cotidiano do turismo apesar deste modelo ter grande aceitação, depara-se com pesquisadores preocupados com suas limitações. Para Machado (2009) algumas lacunas que devem ser observadas: 1) "o perigo da teoria dos sistemas transformar-se em analogias sem significação; 2) o fato de não ir além de perceber que a matemática podia ser aplicada a várias classes de sistemas; 3) a posição de ser apenas uma explicação em princípio". (MACHADO, 2009, p. 10)

Para Moesch (2014) as discussões sistêmicas devem ser vistas de forma crítica, uma vez que o turismo:

[...] é um Fenômeno perceptível e cognossente, que não pode ser explicado por nenhuma lei simples e, portanto nenhum subsistema assim identificado (...) pode ser apreendido senão em sua totalidade e de forma orgânica, ou, seja, em suas relações de completude, complementaridade, determinação e recursividade." (MOESCH, 2014, p. 12)

Portanto, as estratégias de planejamento necessitam de uma releitura de suas metodologias e ferramentas de forma a propor inovações que permitirão a construção de novos paradigmas.

Sonaglio (2013) traz reflexão bastante interessante sobre esse assunto ao propor um novo olhar na construção científica do turismo, sugerindo a superação de questões rotineiras que 0 discutem sob as óticas multi e interdisciplinar para, agora, contemplar as necessidades demandadas pelos elementos constituintes do sistema turístico. Este novo olhar deve organizar-se a partir da perspectiva transdiciplinar tendo como norte a sustentabilidade. Nas palavras da autora:

O turismo vem sendo interpretado, explicado e organizado a partir da base sistêmica, cuja "interação" entre as diferentes disciplinas (interdisciplinaridade) mostrou-se como uma excelente maneira de resolução dos problemas surgidos das "disciplinas" e que não podiam ser resolvidas, isoladamente, na parcialidade disciplinar. No entanto, na dinâmica do turismo, a miríade de problemas surgidos "nas" e "das" interações contraditórias contemporâneas não têm sido solucionada sob o mesmo paradigma que os criaram (sic). Desse modo, é premente o surgimento de um outro paradigma que venha a dar sustentação ao 
desenvolvimento do turismo, na tentativa de alcançar a sustentabilidade. (SONAGLIO, 2013, p. 2010)

A associação do modelo sistêmico de Molina (2005), com as propostas de Krippendorf (2001), guardando as devidas características histórico-sociais, levaria à formulação de um novo modelo de sistema turístico onde as estruturas se relacionam com as práticas e com as políticas, respeitando os interesses dos sujeitos. Portanto, a associação dos resultados desta interação dos modelos citados com a proposta transdisciplinar de Sonaglio (2013) permitirá a análise dos espaços turísticos, priorizando cada uma de suas facetas e a partir do entendimento dos atores locais com interesses públicos e privados.

Todos os conceitos apresentados até o momento apontam contribuições que ampliam o entendimento do turismo, mas ainda existem lacunas que precisam ser melhor trabalhadas. Sem dúvidas o turismo é um fenômeno social, tendo seu planejamento pautado no sistemismo para maximizar os resultados tanto para os atores quanto para os ambientes. Mas até o momento não se apresentou o que é o fenômeno. Como maximizar resultados? Qual o limite entre a satisfação e os impactos? Estas são algumas questões que muitas vezes deixamos de lado, mas que na verdade são essenciais para a compreensão do turismo.

A compreensão do turismo como um fenômeno deve extrapolar a dimensão social, pois, apesar de ter sua dinâmica pautada no comportamento humano, ainda assim depende de espaços naturais, construídos e das interações que envolvem estruturas para atender às cidades e à geração de divisas.

Todos estes componentes que fomentam a interação entre as pessoas também geram relações independentes que podem afetar os resultados negativamente, impactando ambientes e promovendo o desequilíbrio tanto nos espaços naturais como na dinâmica cultural. Consequentemente, as comunidades sofrerão com a readequação dos cenários, principalmente econômicos, já que estes são os que mais influenciam a tomada de decisão dos atores coletivos. Portanto, maximizar os resultados é relevante desde que aconteça o monitoramento das ações planejadas para o desenvolvimento local. 
Nesta perspectiva, o turismo precisa ser entendido como um fenômeno amplo, que tem como limites a compreensão coerente de como satisfazer os desejos e expectativas dos indivíduos, sem desequilibrar a diversidade existente nos ambientes e comprometer o bem-estar dos residentes e possíveis visitantes que ainda não tiveram a oportunidade de conviver nestes destinos.

A partir desta teorização e breve revisão de conceitos já estabelecidos, acredita-se que a melhor compreensão de turismo para este trabalho deverá ultrapassar o já proposto e ser compreendido como um fenômeno capaz de promover o desenvolvimento local de forma a maximizar os benefícios tanto para os turistas quanto para os residentes, minimizando os impactos negativos e promovendo as relações entre todos os atores e elementos envolvidos em sua dinâmica. Isso em muito está relacionado com o proposto por Buarque (1999) ao destacar a importância da dinâmica existente internamente nas comunidades de forma a promover sua transformação.

Portanto, faz-se necessária a inclusão de novas discussões que englobem o lazer e as políticas públicas para que, desta forma, seja possível atender às necessidades de bem-estar social.

\subsection{O LAZER COMO ESSÊNCIA DO TURISMO}

Os estudos sobre o lazer, assim como sobre o turismo, são considerados recentes e em processo de construção ou adequação. Um dos maiores desafios do lazer é promover o bem-estar da sociedade, em seu momento de não trabalho, sem que as pessoas necessitem se distanciar de suas residências. Outro seria a paridade dos conceitos que determinam quem tem direito a esta prática e qual o momento de desfrutar.

Desta forma, ficam evidentes questões de tensão dentro da academia quando é discutida a utilização de termos equivocados ou ambíguos. Para Marcelino (2002, p.8) uma contradição importante no assunto é a do tempo livre, que apesar de apresentar uma conotação de desprendimento na verdade representa que "tempo algum pode ser entendido como livre de coações ou normas de conduta social". Portanto, todas as vezes que se propõe a pensar 
neste tema é fundamental sua integração com todos os valores que cada indivíduo incorpora ao longo de sua vida, pois é a partir desta consciência que as posturas durante o tempo de lazer serão determinadas.

Deve-se estender este método também para o turismo pois, com a facilidade da saída do ambiente rotineiro, muitas vezes é comum observar uma mudança de comportamento por parte do turista que gera situações pouco satisfatórias para as comunidades receptoras e, consequentemente, a criação de imagens inadequadas das culturas e hábitos regionais.

Mas se a terminologia "tempo livre" é utilizada indiscriminadamente, qual a melhor forma de identificarmos as pessoas que têm direito ao lazer? Para Marcelino (2002) seria interessante considerarmos "tempo disponível" pois assim, fica intrínseca a ideia de uma pessoa que já cumpriu com seus compromissos pessoais e profissionais, mas que ainda possui disponibilidade de tempo e atitude para o lazer. Boullón e Molina (2004) mantêm o uso do conceito de tempo livre como:

é o que fica depois que se retira do tempo total dedicado ao trabalho, ao descanso e a outras obrigações secundárias como o deslocamento para o trabalho, a higiene pessoal e a realização dos deveres domésticos. (BOULLON e MOLINA, 2004, p.20)

Caminhando nesta discussão observa-se a importância de se entender - lazer como uma oportunidade de aproximação dos sujeitos residentes e visitantes com interesses convergentes e ocupando áreas comuns. Pellegrin (2006) ao definir lazer, indiretamente permite esta convergência de significados, pois o considera como um fenômeno humano, material e corporal desempenhado em um tempo e espaço determinados, onde estão presentes as relações políticas e históricas.

Gutierrez (2001) complementa esta concepção ao seguir que a busca pela emoção e pelo prazer é o que permite ao homem, enquanto sujeito racional, extrapolar suas necessidades e transformar seu universo em um espaço subjetivo e transitório onde em cada momento estabelecerá circunstâncias de vivência e de motivação.

Portanto são os valores individuais que atuam diretamente no campo do lazer e que poderão determinar sua interface com o turismo, já que as escolhas 
dependem diretamente das construções individuais e da compreensão do que realmente é essencial para o bem-estar e não apenas uma futilidade.

Pronovost (2011) propõe um exame mais analítico deste estudo para estabelecer parâmetros fundamentais como os valores sociais, as normas sociais, de ação, implicação, interação e contextuais. Todos estes elementos direcionam para a ampliação do conceito de lazer enquanto um "ato ou ocupação", a uma conduta. Desta forma, a construção simbólica do espaço de lazer depende da compreensão dos símbolos e da leitura de seus significados.

É por esta razão que a delimitação conceitual torna-se um conflito subjetivo no qual sempre será interposto as expectativas e os interesses tanto em ambientes cotidianos como em momentos de turismo. O que deve-se evitar é a vinculação destes fenômenos ao consumo indiscriminado. Pellegrin (2006, p. 108) alerta sobre esta exploração ao dissertar sobre os desejos individuais.

O sujeito nem consome mais pelo significado ou valor de uso que os
objetos, bens culturais ou experiências têm para ele assim pela
sensação de que ele pode, no seu "tempo livre", comprar objetos e
serviços e assim atingir uma satisfação, uma felicidade e até uma
suposta liberdade, que no fundo revelam-se extremamente subjetivas,
individualizadas e limitadas, claramente circunscritas aos limites de
classe, o que muitas vezes nem chega a ser percebido. (PELLEGRIN,
2006, p. 108)

A contradição estabelecida ao abordar o lazer e o turismo distanciados das questões de consumo retomam à preocupação com as transformações sociais e as relações entre classes, ambos elementos presentes nas discussões que abrangem a convivência nos ambientes capitalistas. Consequentemente, remetem-se à necessidade de interação das políticas públicas de forma a maximizar a distribuição dos benefícios e minimizar as contradições.

Neste sentido, as políticas públicas de turismo, muitas vezes, apontam instrumentos que atendem às práticas de lazer, mas visando atender às possíveis expectativas dos turistas. Simultaneamente o Ministério do Esporte, por meio do Programa de Esporte Lazer e Cidadania, prioriza o incentivo a atividade física das comunidades.

A partir do olhar diferenciado de dois órgãos federais, observamos que o lazer ganha uma dimensão diferenciada e atende a públicos distintos, porém com semelhanças em suas ações e benefícios. Portanto, não seria inadequado 
associá-lo a um movimento em prol da qualidade de vida, tendo como intenção o prazer.

\subsection{UM ENFOQUE NOS ESPAÇOS NATURAIS PARA A PRÁTICA DE LAZER E TURISMO}

A partir desta breve leitura do turismo e do lazer acredita-se ser essencial a interação destes fenômenos com os ambientes naturais que, em grande parte, são os espaços escolhidos para a prática de atividades lúdicas e recreativas que promovem o despertar da realização dos desejos individuais.

Para a compreensão dessas atividades desenvolvidas, deve-se sugerir uma organização mercadológica de forma a segmentá-las conforme a motivação dos turistas. Para tanto, o Ministério do Turismo organizou suas estratégias e ações a partir da construção dos seguintes segmentos: Ecoturismo, Turismo de Aventura, Turismo Cultural, Turismo Náutico, Turismo de Negócios e Eventos, Turismo de Pesca, Turismo Rural, Turismo Social, Turismo de Sol e Praia, Turismo de Saúde, e Turismo de Estudos e Intercâmbio (BRASIL, 2008).

Como a finalidade deste trabalho é a análise do uso múltiplo dos lagos e entorno dos reservatórios, considerando as ações propostas para 0 desenvolvimento do turismo, acredita-se ser relevante apenas as considerações sobre as alternativas de atividade que poderão ser desenvolvidas em áreas naturais.

Ao se suscitar o conceito responsável, necessariamente é preciso estabelecer uma ligação direta com o uso racional dos espaços e, principalmente, com a preocupação com a conservação do meio ambiente natural. Para Pellegrin (2006, p. 115) o ponto de partida é a compreensão da interdependência existente entre o ser humano e a natureza.

(...) A natureza não existe sem o homem e o homem não existe sem a natureza. A natureza de que é possível falar hoje é a natureza humanizada, é a natureza transformada pela ação dos homens e mulheres, é a natureza deste nosso mundo. Portanto o corpo desses homens e mulheres também não pode ser pensado isoladamente: 0 corpo também é uma síntese de determinações, sociais, culturais, econômicas, psicológicas, enfim, de uma série de dimensões da vida humana, que se modificam historicamente. (PELLEGRIN, 2006, p. 115) 
A racionalidade do sujeito deve-se à sua capacidade de compreensão e consciência a partir da qual é possível agregar valores que impossibilitem a degradação e a maximização dos impactos negativos, a partir do uso indiscriminado dos espaços. Complementando este comportamento, torna-se fundamental a compreensão da conservação que para Wearing (2001) corresponde a proteção, manutenção, administração dos recursos naturais de forma a maximizar os benefícios para as gerações, tendo como comprometimento a manutenção da biosfera.

Para a promoção da integração é indispensável o entendimento de área natural como de uso comum para os visitantes e locais. Portanto, pode-se suscitar que o turismo e o lazer poderão ser administrados de forma coletiva atendendo simultaneamente aos interesses individuais dos sujeitos. Portanto, a coordenação da atuação dos atores torna-se elemento essencial para 0 desenvolvimento destas práticas e, assim, os governos, a iniciativa privada e a comunidade precisam estar articulados de forma a estabelecer os caminhos a serem trilhados. Esta interação fica explicitada na reflexão de Gorni e Dreher (2010) ao discutir a responsabilidade dos poderes para o desenvolvimento do turismo de natureza na região de Blumenau (SC).

Uma vez que o turismo de natureza engloba um número significativo de atividades que podem ser desempenhadas em áreas naturais e, acredita-se que uma das propostas em potencial seria o ecoturismo, amplamente discutido nas políticas públicas brasileiras de turismo e de meio ambiente, mas também existe espaço para o turismo de aventura, turismo náutico e o turismo de pesca. Esta diversidade de terminologias tem a ver com as demandas mercadológicas e não com as práticas em si, pois têm como base os princípios da sustentabilidade, segurança, e os dois últimos, o uso múltiplo.

Para Wearing (2001) o ecoturismo propõe um turismo interpretativo, de baixo impacto, discreto, tendo como intenção a conservação, a compreensão do meio ambiente e das comunidades. Neste sentido acredita-se que a implantação de atividades relacionadas a esta tipologia promoverão uma boa interação entre o homem e a natureza, permitindo a reconstrução da biodiversidade abalada durante o processo de represamento do rio e construção da barragem.

Além disto, as práticas desenvolvidas por este público também estão acessíveis à comunidade local, o que possibilita o uso múltiplo do espaço público 
para o turismo e o lazer, ao passo que potencializam as relações de interação entre os visitantes e promovem a construção coletiva de novos hábitos.

Dentre os principais atrativos para atender a este perfil destacam-se: observação de fauna e flora, trilhas, caminhadas, mergulhos livres e safaris fotográficos. Esta delimitação segue, como parâmetro, a proposta do manual "Ecoturismo: Orientações Básicas", publicado pelo Ministério do Turismo em 2010.

Ainda a partir dessa concepção, mas pensando em performances focadas em um público mais desbravador, temos como opção o Turismo de Aventura, que para Vasconcelos et al (2012) refere-se a uma modalidade que preconiza a interação entre o homem e a natureza motivada pelo prazer e risco controlado.

Para este segmento, uma das principais atenções é dada à legislação que regulamenta a segurança nos espaços e equipamentos, de forma a minimizar os riscos assumidos pelo praticante. De forma mais ampla, os turistas e moradores tendem a praticar as atividades de aventura conjuntamente, principalmente por desfrutarem de intenções e atitudes semelhantes e correspondentes ao espírito aventureiro.

Arvorismo, bungeejump, cachoeirismo, canionismo, caminhada de longo percurso, cavalgadas, cicloturismo, espeleoturismo, escalada, montanhismo, tirolesa, boia cross, canoagem, duck, flutuação e mergulho são algumas das atividades compatíveis a esse segmento e aos principais interessados pela área.

Já o Turismo Náutico pressupõe a utilização de embarcações para a movimentação de pessoas tanto em rios, represas, lagos ou mar (BRASIL, 2008). Dentre as principais possibilidades destacam-se: moto aquática (jet ski), balsas, barcos, botes, lanchas, veleiros, dentre outros. Casualmente, este é um dos primeiros segmentos de promoção para a integração do turismo e da recreação nos lagos artificiais, pois apesar de exigir equipamentos de alto custo, pressupõe investimento individual que permitirá a diversão das pessoas que gostam de contato com a água.

Por fim, outro elemento comum, mas com uma motivação bastante particular é o Turismo de Pesca, que para o Ministério do Turismo "compreende as atividades turísticas decorrente das práticas da pesca amadora." Portanto, corresponde ao planejamento da viagem, com todos os serviços e produtos que 
poderão ser adquiridos no destino visitado ou na cidade de origem (Brasil, 2008, p.16)

Em face do até aqui apresentado, pode-se inferir o quanto estamos preparados teórico e legalmente para trabalhar com o turismo e o lazer de forma conjunta e indiscriminada, sempre promovendo encontros sadios e onde os atores reconhecem seus espaços e são capazes de disfrutar de bons momentos.

Ao se analisar o uso do espaço público sempre deve-se pensar no coletivo e como maximizar os benefícios do uso múltiplo e, neste caso, na variedade de atividades e, também, de públicos. Mas deve-se, também, identificar a melhor forma de minimizar os impactos negativos tanto nos âmbitos social como ambiental, cultural e econômico. Desta forma, deve-se priorizar a sustentabilidade no planejamento destes espaços e na educação dos que o visitam.

Muitas são as ações que podem auxiliar na compreensão da sustentabilidade. Assim, cabe aos gestores selecionar o caminho que melhor atenderá às necessidades da comunidade envolvida, e que promoverá a reconstrução de um espaço devastado ambientalmente e culturalmente durante a implantação da barragem.

\subsection{HOSPITALIDADE}

Ao se estabelecer as semelhanças entre turismo e lazer, e elencar as atividades que poderão ser desenvolvidas nas áreas naturais, tanto pelos turistas quanto pelos residentes, faz-se necessário retomar as reflexões de espaço para que fique clara a noção de que a percepção de um estrangeiro, necessariamente, englobará todas as questões que envolvem o cotidiano dinâmico das cidades.

Assim, embora a hospitalidade não esteja comumente entre as discussões que permeiam a implantação do turismo, acredita-se ser necessária uma reconstrução desta lógica, como essência para o desenvolvimento de qualquer ação que tenha como parâmetro o contato entre os que têm interesse em desbravar o espaço e os que já habitam a região,

Cabe destacar que, apesar das relações serem ferramentas cotidianas e influenciadoras do comportamento humano, consequentemente da 
coletividade, ainda assim não existe qualquer política pública focada nesta temática.

\subsubsection{Entendendo os sujeitos}

O entendimento da viagem precisa ultrapassar a mudança de ambiente de forma mecânica, tendo como finalidade somente o repouso e a retomada das energias. É preciso ter ciência de que este deslocamento envolve a necessidade de ruptura com o presente e a construção de novos imaginários que perpetuarão após o retorno ao lar.

Bachelard (1998) apresenta uma reflexão sobre os aspectos fenomenológicos que envolvem a casa enquanto morada física e psicológica. Para o autor, o ser não precisa do deslocamento real para enveredar no movimento do mundo e estabelecer novas relações de morada onde a imagem e o imaginário criam relações que possibilitam o entendimento desta dinâmica. Para tanto, a "casa" torna-se abrigo e espaço de infusão, onde a penetração do outro desperta a intimidade e a possibilidade do acolhimento e compartilhamento. Portanto, cabe ao que chega conquistar a confiança e, de certa forma, quebrar o distanciamento inicial com o que ali reside, para assim transpor a soleira e conhecer o interior da morada.

Mas como entender este ser que vive a vagar à procura de si de forma tão nômade e ativa? Como entender este estrangeiro que ao mesmo tempo não quer uma morada fixa, mas procura por abrigo? Como acolher sem ultrapassar os limites "legais" de uma relação tão tênue e recente? Estas são algumas das perguntas que possibilitam a construção imaginária de alguns dos sujeitos viajantes que ora são turistas, ora caminhantes ou viajantes.

A subjetividade construída a partir destes devaneios tem muito a ver com as incertezas existentes ao se pensar o que motiva a saída do ser de sua comodidade e, por outro lado, como aquele que recebe é sensibilizado a atender a um chamado que não parte do conhecido, ou daquele por quem já se tem estima.

Portanto, num mesmo ambiente temos aquele que veio de outro lugar e está temporariamente visitando aquela região, por isto convivendo com hábitos e tradições que fogem ao seu entendimento pleno. Por outro lado, o morador 
que, ao vivenciar uma realidade que foge ao seu cotidiano, se sente estrangeiro em seu próprio lar. Esta relação de estranheza e estrangeirismo é teorizada por Maldonado (2004) ao discorrer sobre as necessidades e limitações que assolam o relacionamento entre os indivíduos com comportamentos e linguagens diferentes ocupando ambientes comuns.

A viagem torna-se um elemento essencial na discussão deste indivíduo, pois, ao escolher sair de casa e procurar novos rumos desperta-se para os desafios que porventura aparecerão, e é neste momento que são estabelecidos os novos olhares sobre o objeto e a identificação das prioridades. Para Onfray (2009) alguns, ao programar sua fuga, comportam-se como nômades e viajantes, sempre abertos ao novo e na certeza que enfrentará os imprevistos com tranquilidade. Outros, como os turistas, preferem a roteirização de todos os momentos da viagem para minimizar os riscos e não precisar passar por situações de desconforto.

Nestas duas posturas não se pode precisar quem está certo ou errado, pois os objetivos da viagem são estabelecidos a partir das necessidades individuais e devem ser minimamente controlados para evitar o embate com os que moram nos destinos, que por sua vez estão cientes da presença dos estrangeiros, e desejam uma vivência tranquila.

As ambiguidades geradas a partir da relação entre os homens devemse à diversidade de personalidades e culturas que, de forma mais ampla, não devem ser consideradas algo negativo, pois é a partir do singular que se constrói uma realidade mais sensível e leve.

A instauração de regras que norteiam as relações humanas, para Boff (2005), são criadas de forma indireta e descomprometida, não atendendo às nuances que envolvem o dar e o receber, pois, estabelecem-se cenários para a discussão da justiça mínima com todos os níveis, os direitos humanos a partir das melhorias, democracia aberta e perfectível, interculturação e o novo paradigma.

\subsubsection{Um caminho a seguir}

Este contexto incita a construção de um cenário sob o qual as relações interpessoais são criadas e estabelecem o movimento do partir e do chegar ao 
desconhecido. Onde quem recebe viaja sem sair de casa e quem chega constrói uma nova mentalidade sobre o lugar e as pessoas que ali moram. Esta relação de troca pressupõe um afunilamento nas relações de acolhida e exige a criação de regras que permitam a cada um dos envolvidos manter sua individualidade.

Portanto, cria-se o espaço da hospitalidade num contexto em que os indivíduos vivenciam situações de caos cotidianamente. Consequentemente, amplia-se o desejo pela fuga de forma a promover sua própria reinvenção a partir do conhecimento de culturas diferentes onde o outro pode não estar em uma situação em que poderá responder as inquietações que motivaram o deslocamento. Em contraponto, a chegada do novo promove sentimentos díspares como a euforia e a angústia.

Para Derrida (2003), o esgotamento da viagem se dá na dualidade entre a hospitalidade e a hostilidade, pois ao se estabelecer as leis da hospitalidade cria-se um espaço de transgressão onde a subversão leva ao desgaste do encontro e da convivência. Isto visto no cotidiano do lar, permite o entendimento de um dos aspectos desta relação de incertezas, mas é preciso extrapolar esta dimensão microambiental e identificar como é dada a convivência no macroambiente - a cidade.

Essa, na qualidade de espaço de convivência, precisará ser vista de forma coerente e coesa para que, desta forma, possa evoluir em suas necessidades de convívio e proporcionar uma ampliação do bem-estar da coletividade. Portanto, a hospitalidade poderá agregar nos momentos de reflexão e planejamento para, a partir deste ponto inicial, ser extrapolada a ponto de ultrapassar as compreensões do hóspede em relação ao hospedeiro.

Quando a hospitalidade e a hostilidade tornam-se elementos prioritários na relação turista/comunidade, todo este cenário, por mais que tenha relação com as despreocupações e promessas do turismo como "salvação econômica" de destinos marginalizados ou com poucos recursos, ainda assim, podem ser resolvidas se a governança local estabelecer novos parâmetros de trabalho e, consequentemente, novas metas para o planejamento estratégico participativo.

Por mais que existam desgastes nas relações, é possível a busca da harmonia a partir de uma nova organização embasada em compreensões sólidas, como a proposta por Grinover (2007) que determina a hospitalidade 
enquanto lei universal que pressupõe a acolhida e a garantia da cidadania. Ou seja:

(...) uma relação especializada entre dois atores: aquele que recebe e aquele que é recebido; ela se refere à relação entre um, ou mais hospedes, e uma instituição, uma organização social, isto é uma organização integrada em um sistema, que pode ser institucional, público ou privado, ou familiar. (GRINOVER, 2007, p.25)

Os elementos mencionados reforçam o dinamismo existente nas cidades $\mathrm{e}$ as consequências que poderão ser geradas nas relações interpessoais entre moradores e turistas nos encontros casuais que porventura acontecerão nos passeios pela cidade, na acolhida dos hotéis, restaurantes e atrativos, assim como em possíveis demandas de saúde e transporte.

Além destes atributos, deve-se considerar categorias de saber que ultrapassam as convenções e discorrem sobre o entendimento da cidade como uma imagem construída a partir de boas práticas que proporcionarão maior acessibilidade, legibilidade e identidade. Para os gestores de turismo, uma das principais discussões recai sobre esta última - a identidade, principalmente no que tange as questões de tradição, mas de qualquer forma não se avança nesta construção, uma vez que o pertencimento nem sempre é um elemento comum às comunidades.

Por mais que estas constatações se aproximem de discursos fadados à utopia, ainda assim deverão ser explorados exaustivamente, pois é a partir da imagem dos destinos que os turistas são despertados para a escolha de viajar, e de optar pelo destino que melhor atenderá às suas expectativas como sujeitos em movimento e à procura de seu ser.

Esta subjetividade criada para as cidades exige um olhar criterioso para acompanhar as nuances criadas a partir das percepções dos turistas, pois será a partir delas que as estratégias de planejamento poderão atender de forma objetiva aos desejos de todos. Para Castelli (2010), além de considerarmos as categorias propostas por Boff, precisamos nos comprometer com os princípios básicos da hospitalidade que englobam a segurança, cortesia, atenção contínua e coerência. Todos estes aspectos dependerão diretamente das ações participativas estabelecidas pelos setores público e privado que convergirão para a ampliação dos benefícios dos moradores, como forma de equidade com os desejos dos hóspedes. 
Desta forma, a busca pela hospitalidade deve tangenciar questões práticas para promover a melhoria das relações. Por isto, a compreensão da hospitalidade social ou pública, proposta por Lashleye Morrison (2004, p 5-6.) "considera os cenários sociais em que a hospitalidade e os atos ligados à condição de hospitalidade ocorrem junto com os impactos de forças sociais sobre a produção e o consumo", ou seja, não é viável isolar as relações interpessoais da dinâmica social do dia a dia, pois as pessoas se encontram neste caos de acontecimentos e emoções.

Uma vez que se assume a importância do cotidiano na discussão da hospitalidade, espera-se que as dimensões discutidas sejam melhor delimitadas, para desta forma permitir maior conexão com a prática do turismo e da sustentabilidade. Portanto, Castelli (2010) ao delimitar a cultura da hospitalidade a relaciona à postura organizacional e suas implicações na prestação de serviços, considerando a importância da inclusão de novas formas de interpretar as relações existentes entre o convívio estrangeiro e residente.

A partir desta reflexão poderemos aprofundar as questões metodológicas e as análises do turismo e do lazer, enquanto instrumentos de promoção e estabelecimento de qualidade de vida para as comunidades atingidas pela construção das barragens de hidrelétrica. Isto considerando como norteadora a política pública assegurada pelo CONAMA em 2002 que, por meio do PACUERA, estabelece que estas duas ferramentas são alternativas de uso do reservatório de forma comprometida, priorizando uma gestão participativa do ponto de vista do público/privado.

Deste modo, o próximo capítulo se resguardará em formatar a lógica da metodologia estabelecida neste trabalho, assim como a descrição dos estudos de caso que foram estruturados para esta pesquisa. Nesta sequência, o Capítulo 2 propõe apresentar os resultados formatados a partir da coleta de dados.

\section{CAPÍTULO 2: DAS POLÍTICAS PÚBlicAS À CONSTRUÇÃO METODOLÓGICA}

A partir da breve teorização sobre os principais elementos que compõem o cenário da discussão dos usos múltiplos dos espaços e das relações 
estabelecidas a partir da convivência, acredita-se ser relevante direcionar a discussão de forma a apresentar delimitações sólidas sobre como as políticas públicas acontecem e em que medida elas promovem a relação entre o meio ambiente e o turismo.

Na sequência, será apresentado o caminho metodológico adotado neste estudo e, consequentemente, as estratégias de interpretação dos dados levantados. Para tanto, fez-se necessária a caracterização das UHEs em estudo, assim como dos municípios de seu entorno. Cabe destacar que, em função da brevidade de tempo, não foi possível a visitação dos empreendimentos.

\subsection{POLÍTICAS PÚBLICAS COMO INSTRUMENTO DE DECISÃO}

A construção do cenário político envolve a fusão ou sobreposição de uma série de atores com interesses e ações independentes, mas com possibilidades de ajustes mediante permutas, nas quais ora são favorecidos determinados grupos, ora outros. No campo do turismo e do meio ambiente, estas negociações são explícitas, uma vez que se trata de situações onde alguns atores posicionam-se nos extremos, tanto na busca da preservação das áreas naturais quanto na sua exploração exacerbada.

O processo decisório, muitas vezes, permite a sobreposição dos interesses e preferências individuais de um ator coletivo em detrimento aos de outros que também estejam envolvidos na barganha política. Mas esse é apenas um dos ruídos existentes no processo decisório, pois são frequentes os casos de ambiguidades e incertezas estabelecidas para cada uma das propostas apresentadas nas rodadas de negociação.

Para Manski (2010), os pressupostos estabelecidos devem servir como base para as escolhas, trazendo clareza e reduzindo as ambiguidades que podem ser entendidas de forma diversificada para uma mesma temática quando analisadas por pessoas com prioridades diferentes. As incertezas, que retratam as fragilidades de cada uma das premissas que poderão se tornar uma regra ou convenção adotada pela coletividade, também devem nortear o processo de análise e avaliação das políticas públicas. 
Desta forma, a generalização de conceitos como o de "decisão" atribui ao discurso fraquezas nas quais algumas considerações poderão refletir aspectos do cotidiano das políticas, mas que, por outro lado, não devem ser tomados como certezas absolutas. Dentro de um processo decisório, apesar de ser possível reduzir as incertezas, existem cenários de risco onde as organizações devem adotar uma postura correspondente às expectativas das instituições.

Portanto, a racionalidade dos atores sociais ou coletivos deveria ser limitada, ou seja, os responsáveis pela tomada de decisão devem ser capazes de atribuir alternativas para suas preferências e, necessariamente, elencá-las de forma prioritária e lógica. Contudo, no dia a dia, os indivíduos alcançam apenas a primeira etapa deste processo, atribuindo apenas uma certa probabilidade ao processo de escolha. Esta reflexão, para March (2009), permite uma nova compreensão das políticas a partir da racionalidade atribuída aos atores e dos reflexos em seu comportamento.

Avançando nesta discussão, acredita-se que uma atenção diferenciada deva ser dada aos atores responsáveis pela administração pública e pela implantação e gestão das regras estabelecidas, pois neste jogo político estes dois grupos são peças fundamentais para os arranjos de grupos de pressão que possuem poder limitado dentro dos governos, no que tange à organização das agendas.

Kingdon (2001) trabalha a temática da organização das agendas de forma a ampliar o número de instituições que atuam no processo de tomada de decisão o que, de certa forma, se aproxima do caso brasileiro, pois delimita os atores e cenários que poderão influenciar diretamente na escolha das pautas que serão discutidas pelos atores coletivos durante a apresentação das evidências e na criação de alternativas que atenderão as preferências desses atores.

Todavia, observa-se que, apesar de se atribuírem responsabilidades a poucos grupos, existe uma série de atores sociais responsáveis pela formação de coalizões e pressões que possibilitam o reordenamento das prioridades dentro da criação da agenda governamental. Além disto, deve-se considerar como são processadas as informações dentro das organizações, pois é a partir 
deste andamento que será possível identificar quais assuntos são essenciais para o cenário global sob o qual a agenda está colocada (KINGDON, 2001).

Jones e Baumgartner (2012) refletem sobre os processos de criação de evidências ao apresentar dois modelos que atendem ao andamento interno das informações, sendo eles o processamento serial e o paralelo. O primeiro normalmente representa o resultado das análises feitas pelos subsetores e que chegarão à mesa dos tomadores de decisão. Por sua vez, o processamento em paralelo ocorre dentro de um corpo organizacional responsável pela análise de dados específicos, priorizando as necessidades e ponderando quanto às consequências que acarretarão ao governo.

Este modelo de análise permite a compreensão das políticas públicas como um complexo universo, onde o jogo político promove a ampliação do número de atores com racionalidade limitada e com capacidade de modificação mediante a dinâmica dos cenários e a criação de novas adequações e incrementos.

Assim, fica evidente que no cenário político não é possível desenhar um jogo de poder estático entre posição e oposição se revezando, mas um ambiente de coalizões visando à maximização dos resultados positivos dentro de preferências variadas. Portanto, a tomada de decisão demanda dos sujeitos coletivos a construção de argumentos adequados e capazes de despertar os grupos de interesse de forma a aprovar as pautas.

Foucault (2013) destaca a importância do discurso no interior das arenas políticas como forma de apoderamento, onde o não dito pressupõe questões fundamentais para o debate. A veracidade dos fatos ultrapassa a lógica, possibilitando a multiplicidade de falas capazes de redirecionar as decisões e delinear novos símbolos.

Para esta dissertação, os discursos verbais são elementos prioritários de interpretação das políticas públicas ambientais para, assim, possibilitar uma interlocução com o turismo permitindo a recriação de saberes. Por sua vez, os não verbais fundamentam de forma indireta a construção dos grupos de coalizão, que são elementos decisivos dentro da arena política para a aprovação das legislações. 
Priorizando o exposto, mais adiante serão apresentadas algumas questões referentes às políticas públicas de turismo e de meio ambiente, que fundamentam o Capítulo 3 que discutirá os dados coletados.

2.1.1. Política Pública como processo de interação institucional e promoção do uso coletivo

A trajetória das políticas públicas de meio ambiente e de turismo assemelha-se tanto na institucionalização de suas pastas autônomas como na construção coletiva de normas e regras que necessitam da cooperação de outros ministérios. Assim, são frequentes nas legislações vigentes a identificação de temáticas semelhantes contempladas pelo Ministério da Pesca, das Cidades, do Planejamento, de Minas e Energia, da Cultura e outros.

$\mathrm{Na}$ tentativa de ilustrar essa interação entre o Ministério do Meio Ambiente e do Ministério do Turismo cabe uma rápida apresentação dos caminhos históricos que acompanharam as discussões sobre as políticas que possibilitam o uso do meio ambiente pelo turismo e permitem certa autonomia na escolha das ações e estratégias prioritárias para os governos.

A atuação pública na área do turismo iniciou-se na década de 1930, com a Comissão permanente de exposições e Feiras (Decreto $n^{\circ} 24.163 / 1934$ ), mas com 0 andamento dado às políticas fez-se necessária a criação do Departamento de Imprensa e Propaganda e, neste, da Divisão de Turismo (Decreto no 1.915/1939), possibilitando a ampliação das atividades desenvolvidas e promovendo a visibilidade do segmento. Na década de 1940, à medida em que novos acontecimentos nacionais e internacionais se intensificaram, observou-se a necessidade de uma atuação mais pautada na imigração (Departamento Nacional de Imigração e Colonização vinculado ao Ministério do Trabalho, Indústria e Comércio). Apenas a partir de $1966 \mathrm{com}$ a criação da EMBRATUR - Empresa Brasileira de Turismo (Decreto n 55/1966), posteriormente transformada em Instituto Brasileiro de Turismo (Lei $\mathrm{n}^{\circ}$ 8.181/1991), identificou-se maior comprometimento com o desenvolvimento do turismo e a criação de uma marca. 
Em 1992, percebendo-se a necessidade de uma atuação mais ampla, instituiu-se o Ministério da Indústria, Comércio e Turismo para amparar legalmente parte das atividades estabelecidas pela autarquia. Neste período, estabeleceu-se por meio do Decreto n448/1992 a Política Nacional de Turismo (PLANTUR).

Posteriormente institucionalizou-se o Programa de Municipalização do Turismo. Com a crescente demanda de ações e estratégias, em 1999 o Governo Federal transferiu a competência da gestão do turismo para o Ministério do Esporte (Medida Provisória oㅡ 2.216-37/2001). Por fim, a partir de 2003, o Ministério do Turismo foi estabelecido como pasta autônoma pela Medida Provisória no 103 de $1^{\circ}$ de janeiro de 2003, convertida na Lei no 10.683 de 28 de maio de 2003.

$\mathrm{Na}$ composição dessa discussão cabe retomar o ambiente histórico sobre o qual se desenvolveram as discussões relativas ao meio ambiente e a criação do Ministério do Meio Ambiente, que hoje é constituído por órgãos reguladores e fiscalizadores como a Agência Nacional de Águas (ANA), IBAMA, e Instituto Chico Mendes de Conservação da Biodiversidade (ICMBio).

Os discursos sobre o ambiente natural iniciaram-se na década de 1932, com a realização da primeira Conferência Brasileira de Proteção à Natureza e, em 1934 com a aprovação do primeiro Código Florestal, revogado em 1965 pela Lei $4.771 / 65$ que, por muitos anos, foi considerado um dos melhores instrumentos brasileiro de preservação ambiental, mas em função de pressões políticas foi substituído pela Lei n¹2.651/2012.

A partir da década de 1960, cabe chamar atenção para a mudança de postura adotada principalmente pelos países ocidentais, ao demonstrarem preocupação com a preservação e a conservação da biodiversidade, subsidiados pelos estudos do Clube de Roma que sugeriu a adoção do "crescimento zero". Nessa oportunidade, a Organização das Nações Unidas organizou a Conferência das Nações Unidas sobre Meio Ambiente Humano (1972), em Estocolmo, onde dentre as muitas agendas foram discutidas questões básicas sobre a preservação do planeta e a continuidade da vida. Assim, foram estabelecidos princípios e recomendações que priorizaram a manutenção da natureza e o bem-estar do homem. 
Acompanhando esta tendência mundial, o Brasil aprovou, em 1981, a Política Nacional de Meio Ambiente que tem como objetivo:

“a preservação, melhoria e recuperação da qualidade ambiental propícias à vida, visando assegurar, no país, a condição de desenvolvimento socioeconômico, os interesses da segurança nacional e a proteção da dignidade humana." (Lei $\mathrm{n}^{\circ}$ 6.938/1981, Art. $2^{\circ}$.).

Essa lei conduz, de forma incisiva, a atuação dos ministérios que, direta ou indiretamente, utilizam os recursos naturais classificando as atividades de forma escalar (alto/médio/pequeno) como poluidoras. Nessa escala, o turismo fica enquadrado como baixo poluidor. Provavelmente essa determinação associada à Constituição Federal fez com que o setor turístico se tornasse uma oportunidade de uso múltiplo para as áreas públicas.

No final da década de 80, objetivando o melhor desenvolvimento das ações estabelecidas pela Política Nacional de Meio Ambiente, é criado o Instituto Brasileiro de Meio Ambiente e dos Recursos Naturais Renováveis - IBAMA, pela Lei $n^{\circ} 7.735$ de 22 de fevereiro de 1989, o qual tornou-se responsável, inicialmente, por "formular, coordenar, executar e fazer executar a Política Nacional de Meio Ambiente e da preservação e conservação e uso racional, fiscalização, controle e fomento dos recursos naturais renováveis. Foi alterada pela Lei $n^{\circ} 11.516$ de 2007 após a criação do Ministério do Meio Ambiente em 1992 (Lei 8.490 de 19 de novembro1992) e, posteriormente, pela Lei 8.746 de 9 de dezembro de 1993.

\subsubsection{Licenciamento ambiental}

A partir da criação do Conselho Nacional de Meio Ambiente (CONAMA) em 1983, as regulamentações para atender às determinações da Política Nacional de Meio Ambiente tornaram-se competência desse órgão. Dentre as determinações estabelecidas para as usinas hidrelétricas, a Resolução $n^{\circ} 1$ de 1986 caracteriza impacto ambiental como "qualquer alteração das propriedades físicas, químicas e biológicas do meio ambiente, causada por qualquer forma de matéria ou energia resultante das atividades humana"; para tanto faz-se 
necessário o estudo de impacto ambiental e a elaboração do RIMA - Relatório de Impacto Ambiental.

Apesar da citada resolução regulamentar a importância do Estudo de Impacto Ambiental (EIA) e do RIMA para a construção de hidrelétricas, a resolução $n^{\circ} 6$ de 1986 desenvolve a temática de forma mais ampla apontando:

Art. 40 Na hipótese dos empreendimentos de aproveitamento
hidroelétrico, respeitadas as peculiaridades de cada caso, a Licença
Prévia (LP) deverá ser requerida no início do estudo de viabilidade da
Usina; a Licença de Instalação (LI) deverá ser obtida antes da
realização da Licitação para construção do empreendimento e a
Licença de Operação (LO) deverá ser obtida antes do fechamento da
barragem. (BRASIL, 1986)

Cronologicamente, as ações acontecem a partir da solicitação da Licença Prévia (LP) quando as concessionárias deverão apresentar o RIMA, apontando o andamento, dentre outros, dos estudos da área a ser atingida e os impactos gerados a partir da implantação do empreendimento. O andamento dado após a LP é a solicitação da Licença de Instalação (LI) que exige das empreiteiras a entrega do relatório de viabilidade. Somente após a concessão destas duas licenças é liberada a Licença de Operação (LO). Curiosamente, o PACUERA, objeto destas reflexões, ainda não é considerado instrumento obrigatório para a outorga de licença, apesar de ser indispensável para a renovação da concessão.

Em 1997, o Conselho Nacional de Meio Ambiente, por meio da Resolução $n^{\circ} 237$, apresentou nova redação e mais esclarecimentos sobre a temática do licenciamento mantendo, contudo, a obrigatoriedade da existência de todas as etapas descritas na Resolução n 6/1987. Apenas em 2002, após a criação do Conselho Nacional de Recursos Hídricos (Decreto lei n².612/1998) e da Agência Nacional de Águas (Lei n 9984/2000), estabeleceram-se novos parâmetros para o uso de áreas de preservação ambiental, inclusive para as criadas a partir do represamento de rios para construção de hidrelétricas. Nesse momento foi estabelecida a obrigatoriedade de apresentação de Plano Ambiental de Conservação e Uso do Entorno de Reservatório Artificial (PACUERA / PCAU) permitindo a indicação de áreas de polo turístico e lazer. 


\subsection{CAMINHO METODOLÓGICO}

A construção do conhecimento científico rompe com as barreiras do padrão formal onde, a partir da experimentação, chega-se a resultados palpáveis a ponto de serem criadas verdades sobre o objeto de estudo. Mas, no campo das Ciências Sociais Aplicadas, a subjetividade existente nestas pesquisas gera distorções e equívocos que não contribuem para o seu avanço. Desta forma, é fundamental que o pesquisador escolha o caminho metodológico que melhor atenda aos seus objetivos.

O estabelecimento destes parâmetros tende a mistificar as obras criadas a partir das Ciências Sociais ao apontar os métodos e técnicas como cenários e instrumentos de incertezas onde as interpretações são resultado de análises pessoais acompanhadas dos pré-conceitos já estabelecidos pelo investigador.

Portanto, para as pesquisas sociais alcançarem o caráter científico esperado pelas ciências "duras" é preciso descrever a lógica dada à construção do trabalho, assim como os limites que serão estabelecidos de forma a não comprometer a contribuição teórica gerada a partir da investigação.

Extrapolando estas necessidades, observa-se a importância de se incorporar novos elementos como a vigilância epistemológica proposta por Bachelard, interpretada por Melo (2006), onde se indaga ao pesquisador sobre sua postura frente aos dados em prol da organização de texto sem a pretensão de assumir a veracidade da teoria antes mesmo de se aprofundar nas contribuições anteriores de outros autores.

A sistematização do conhecimento traz para a pesquisa a possibilidade de se estabelecer uma lógica que a direcionará para a distinção entre o papel da investigação qualitativa ou quantitativa. Para esta dissertação entende-se que a investigação qualitativa se aliará às oportunidades de análise do objeto de estudo e responderá às inquietações apontadas, tanto nos objetivos como nas questões de pesquisa.

Desta forma, a utilização da pesquisa qualitativa permitiu o entendimento a partir da compreensão do subjetivo existente na realidade. Para Denzinet al. (2006) este tipo de abordagem permite o uso de uma variedade de estudos de 
casos que descrevem momentos e significados rotineiros e problemáticos na vida dos indivíduos.

Com base nesta contextualização, pretendeu-se estudar os dados com profundidade, utilizando a pesquisa exploratória e explicativa, pois esta permitiu a identificação e análise das perspectivas criadas a partir da delimitação do objeto de estudo.

A escolha pela pesquisa exploratória deve-se à necessidade do trabalho investigativo para a coleta de dados de fontes primárias, as quais possibilitam a construção de instrumentos de pesquisas capazes de nortear o desenvolvimento do trabalho. Para Dencker (2000):

A pesquisa exploratória procura aprimorar ideias ou descobrir intuições. Caracteriza-se por possuir um planejamento flexível envolvendo em geral levantamento bibliográfico, entrevista com pessoas experientes e análise de exemplos similares. (DENCKER, 2000, p. 30)

Por sua vez, a pesquisa explicativa possibilitou a análise e a interpretação dos dados a partir do estabelecimento de parâmetros. Para Dencker (2000, p.31) tal pesquisa "procura identificar os fatores que determinam ou contribuem para a ocorrência dos fenômenos".

Considerando a relevância da escolha do tipo de pesquisa, faz-se necessária a identificação da organização das ideias considerando a definição do método que promoveu a melhor articulação entre os dados e as informações coletadas. Portanto, a dialética permitiu neste estudo uma reflexão interpretativa aprofundada sobre as oposições e as tensões que ocorrem no cotidiano dos atores envolvidos no processo decisório das políticas públicas. Bruyne (1997) reflete sobre o papel da dialética num contexto dinâmico de incertezas e contradições.

O pensamento dialético pode então definir-se por seu movimento de totalização que é essencialmente um movimento progressivoregressivo de abertura para o concreto em transformação. (BRUYNE, 1997, p.71)

Demo (2013) contribui ao apresentar uma discussão sobre características essenciais da dialética materialista, permitindo a construção da "metodologia da roda viva" sobre a qual a dinâmica das relações sociais proporciona uma convivência polarizada e sobre a qual o jogo de poder entre os 
sujeitos leva a transformações e mudanças de argumentação de forma a estabelecer a unidade de contrários.

Assim, nesta dissertação priorizou-se a interpretação dos conceitos a partir da criação de uma lógica sobre a qual os constructos orientaram as escolhas das técnicas que permitiram a estruturação das etapas da pesquisa. A utilização da dialética materialista estruturalista como quadro interpretativo proporcionou a identificação da estrutura do fenômeno penetrando em sua essência para definir suas ligações determinantes. Para Bruyne (1997):

Essa metodologia requer uma crítica prévia do domínio estudado, do
objeto e do procedimento, uma crítica das reduções e extrapolações,
uma determinação do grau de coerência do objeto. É um pensamento
que se move no tempo mas que se inscreve no espaço, que vai de
forma lógica, racional, ao conteúdo prático. (BRUYNE, 1997, p.68).

Para melhor atender aos objetivos propostos nesta dissertação, acredita-se ter sido indispensável a reflexão sobre as teorias e a legislação referentes à temática discutida, tendo como técnica a pesquisa bibliográfica, o levantamento documental e o estudo de caso, que em grande escala permite a ilustração das demandas estabelecidas pela legislação.

Neste contexto, a pesquisa bibliográfica orientou a construção do objeto de estudo e destacou as principais contribuições já deixadas por outros pesquisadores, permitindo à investigadora uma leitura ampla, que também foi avaliada com prudência já que dependem diretamente dos processos de pesquisadas estabelecidos pelos autores (GIL, 2007).

Essa busca pela teoria, em fontes primárias, é fundamental, ao passo que permite identificação de estudos anteriores que porventura analisaram problemas de pesquisa com certa similaridade à proposta pelo estudo corrente a partir de outro viés. Paviani (2009) aponta a teorização como uma estrutura de caráter instrumental e dinâmico. Por isso muitas vezes torna-se perecível a ponto de exigir revisões e novas construções para a descrição e explicação dos fatos.

Assim, a construção da fundamentação teórica deste estudo foi embasada nas teorias disponíveis em livros e artigos científicos. Para as análises e construção de quadros interpretativos foram utilizadas reportagens digitais, que circularam no período entre 2000 e 2013, portanto, foram identificados os principais discursos adotados pelos grupos de interesse. 
A segunda etapa constitui no levantamento documental que "vale-se de matérias que não receberam ainda um tratamento analítico, ou que ainda podem ser reelaboradas de acordo com os objetivos da pesquisa" (GIL, 2007, p.66). Arquivos primários, como legislações disponíveis no site do IBAMA e JUSBRASIL, considerados documentos fundamentais para a concessão do licenciamento ambiental foram utilizados. Dentre estes destacam-se atas de audiências e consultas públicas, pareceres técnicos e Plano Ambiental de Uso do Entorno de Reservatório Artificial - PACUERA/PCAU. Para dialogar com estes documentos foram trazidas as leis federais e resoluções que normatizam o uso dos reservatórios.

Finalmente, o estudo de caso foi adotado como estratégia de pesquisa para identificação de realidades semelhantes, mas extrapoladas a partir de suas particularidades. A escolha dos casos considerou a relevância de suas contribuições a partir da similaridade de documentos aprovados pelo IBAMA. Cabe destacar que esta técnica é utilizada com frequência em pesquisas sociais, pois permite a investigação do fenômeno a partir de suas variáveis que nem sempre são controláveis. Para Yin (2001):

(...) o estudo de caso como estratégia de pesquisa compreende um método que abrange tudo - com a lógica de planejamento incorporando abordagens específicas à Coleta de dados e à análise de dados. (YIN, 2001, p.33)

Durante o processo de determinação dos casos em estudo optou-se pela busca de informações no sítio eletrônico da Agência Nacional de Energia Elétrica - ANEEL e do IBAMA para que, a partir do cruzamento das informações de Usinas Hidrelétricas - UHEs encontradas no Atlas da Energia Elétrica do Brasil (2008), fosse possível a identificação dos processos de licenciamento em andamento. Foram priorizados na escolha os equipamentos que já possuíam o Plano Ambiental de Uso do Entorno do Reservatório - PACUERA, aprovados até o primeiro trimestre de 2014.

A partir desses levantamentos dois empreendimentos foram selecionados a UHE Corumbá IV, no Estado de Goiás e a UHE Barra Grande, entre os Estados do Rio Grande do Sul e Santa Catarina. Mais à frente, estes ambientes serão descritos de forma a possibilitar a melhor visualização dos 
cenários e das condições vivenciadas pelos atores envolvidos no processo de implantação do turismo nessas áreas.

2.2.1. Instrumentos de análise e interpretação dos dados

Uma vez que a coleta de dados em pesquisas científicas representa uma das principais etapas de sua execução, acredita-se que o detalhamento dos instrumentos utilizados neste trabalho permitirá a melhor compreensão das análises apresentadas no Capitulo 3 desta dissertação.

Durante o processo de construção metodológica optou-se por aplicar como pré-teste um roteiro de entrevista (Apêndice 1) para identificar as possíveis lacunas e necessidades de reestruturação. Observou-se que as perguntas foram claras, contudo as respostas não atingiram o esperado, pois a implantação da Resolução CONAMA 302 acontece de forma lenta e sem a interação entre outras pastas para que, assim, todos os requisitos exigidos fossem colocados em prática.

Para melhor exemplificar o ocorrido destacamos que, para o IBAMA, apesar de ser necessária a aprovação do PACUERA com alternativas de uso para os reservatórios, não foi estabelecido quem será o responsável pelo acompanhamento destas estratégias, já que a competência do órgão restringese à fiscalização da área de proteção ambiental.

A partir desta constatação utilizou-se o mesmo roteiro de entrevista para identificar o entendimento da Agência Nacional de Águas, do Ministério do Turismo e dos Consórcios, para entender como cada um destes atores percebe a política pública vigente no que se refere ao uso do turismo nas hidrelétricas.

As informações coletadas foram analisadas e interpretadas a partir da triangulação de dados que, para Triviños (2012), permite "abranger a máxima amplitude na descrição, explicação e compreensão do foco em estudo".

Uma vez que existe disponibilidade de grande parte dos documentos referentes ao processo decisório que engloba a aprovação dos Planos Ambientais, pretende-se a partir da ferramenta AdvocacyCoalition FrameworkACF identificar os principais axiomas formadas pelos grupos políticos durante a aprovação do PACUERA / PCAU de cada um dos casos em estudo. Para a UHE Corumbá IV e a de Barra Grande foram analisadas reportagens do período de 
2000 a 2013, período superior ao de aprovação dos Planos, uma vez que os dois empreendimentos assinaram termo de ajuste de conduta e precisaram desenvolver algumas ações após a aprovação dos instrumentos (PACUERA/PCAU).

Este modelo de análise permitiu identificar como os envolvidos na tomada de decisão gerenciam os conflitos de objetivos, tendências ideológicas e as diferenças técnicas relevantes (SABATIER e WEIBLE, 2007). Em função do problema de pesquisa acreditou-se ser relevante a utilização de um recorte do framework proposto pelos autores, assim foram identificadas as crenças, do subsistema político dos dois empreendimentos em estudo, determinando os núcleos duro, político e os aspectos institucionais.

Ainda para as hidrelétricas foram consideradas as atas das audiências públicas, os relatórios disponíveis no sítio eletrônico do IBAMA e de cada uma delas. Neste último caso deu-se prioridade ao PACUERA ou PCAU, conforme denominações registradas nos sítios eletrônicos.

As análises a partir desse framework exigem a criação de códigos sob os quais não incida a possibilidade de adequação do conteúdo em mais de um deles, o que exigiu a atenção na elaboração das variáveis e a busca de pessoas competentes capazes de validá-las.

O entendimento dos papéis desempenhados por cada um dos atores envolvidos no processo decisório que tem como foco uma discussão ambiental polêmica e que muitas vezes é utilizada de forma equivocada para fazer manobras e aprovar projetos que não atendem às necessidades da coletividade possibilitam a identificação dos empecilhos que porventura atrasam a implantação do turismo nas regiões atingidas por barragem, assim como reduz a distância do processo de inclusão da comunidade atingida tanto na prática do lazer como na participação das atividades produtivas.

Portanto, os objetivos propostos nesta dissertação foram alcançados a partir dos processos metodológicos citados e permitiram a construção do saber científico coeso e coerente onde a subjetividade deixa de ser um entreposto e torna-se um instrumento de interpretação e criação de novas compreensões. 


\subsection{DELIMITAÇÃO DOS ESTUDOS DE CASO}

Considerando a relevância do trabalho científico para a discussão da utilização do turismo como alternativa de uso múltiplo das águas e, consequentemente, de seu entorno, optou-se pela identificação dos empreendimentos que já obtiveram a aprovação de seus Planos de Conservação Ambiental e Usos da Água e do Entorno do Reservatório regulamentado pela Resolução CONAMA 302/2002. Para tanto, utilizou-se como primeira aproximação a síntese das informações disponíveis no anexo do Atlas da Energia Elétrica do Brasil - ANEEL (2008). Nesta etapa foram identificados 747 empreendimentos em diferentes estágios de implantação.

A partir de então identificou-se no sítio eletrônico do IBAMA as usinas hidrelétricas e pequenas centrais hidrelétricas com licenciamento aprovado chegando-se a 93 UHEs e 43 Pequenas Centrais Hidrelétricas (PCHs). Destas, apenas CORUMBA IV apresentava o PACUERA com aprovação designada nos protocolos do sítio. Considerando o longo prazo de vigência da resolução fez-se necessário o contato por ofício com o órgão competente para certificação. Nesta oportunidade identificou-se que, por questões operacionais, o Plano teve alteração na sigla passando a ser chamado PCAU, e que a UHE Barra Grande também já havia recebido sua aprovação.

Cabe destacar que a constituição do PACUERA possibilita a identificação tanto do diagnóstico quanto do prognóstico das regiões atingidas pelo alagamento, indicando as características físicas, biológicas, socioculturais e econômicas da região, seus pontos de maior comprometimento e suas perspectivas sobre as questões ambientais e socioeconômicas. A sua metodologia de construção torna-se ferramenta indispensável para leitura crítica do documento, pois identifica as frentes adotadas pelos gestores e suas escolhas durante o processo de implantação do reservatório.

Especificamente para esse trabalho foram consideradas as ações previstas para o turismo como uma alternativa de uso das águas de forma a priorizar o desenvolvimento das localidades atingidas.

Entretanto, o Plano Ambiental não se configura, por si só, como agente de transformação do cenário existente na área, devendo fazer parte de um aparato mais amplo, articulado por um sistema de gestão eficiente, 
no qual as articulações adequadas entre os diferentes agentes que intervêm no espaço econômico são determinantes, deste modo, este projeto também tem por objetivo dar apoio aos municípios para gerar legislações em zonas rurais lindeiras ao reservatório para uso e parcelamento do solo, desenvolvimento de atividades de lazer e turismo, além dos acessos. (WALM, 2011, p.5)

Acreditando na relevância do recorte optou-se pela análise dos documentos e reportagens referentes a estes dois equipamentos. Assim, faz-se necessária a caracterização dos municípios identificados e referenciados pelas empreiteiras nos planos ambientais. Quando possível, optou-se por uma breve contextualização dos cenários turísticos pré-estabelecidos.

\subsubsection{UHE Barra Grande}

A Usina Hidrelétrica de Barra Grande ocupa uma área de $12.052 \mathrm{~km}^{2} \mathrm{com}$ potência instalada de $690 \mathrm{MW}$. Desses, $6.040 \mathrm{~km}^{2}$ pertencem ao Estado de Santa Catarina, enquanto $6.012 \mathrm{~km}^{2}$ constituem o Rio Grande do Sul. O reservatório ocupa uma área equivalente a $94 \mathrm{~km}^{2}$ atingindo os municípios de Anita Garibaldi, Campo Belo do Sul, Capão Alto, Cerro Negro e Lages em Santa Catarina; Pinhal da Serra, Esmeralda, Vacaria e Bom Jesus no Rio Grande do Sul, conforme estabelecido no PCAU e apresentado na Figura 1. As águas que o alimentam são provenientes do Rio Pelotas que corta os dois estados sulistas. 


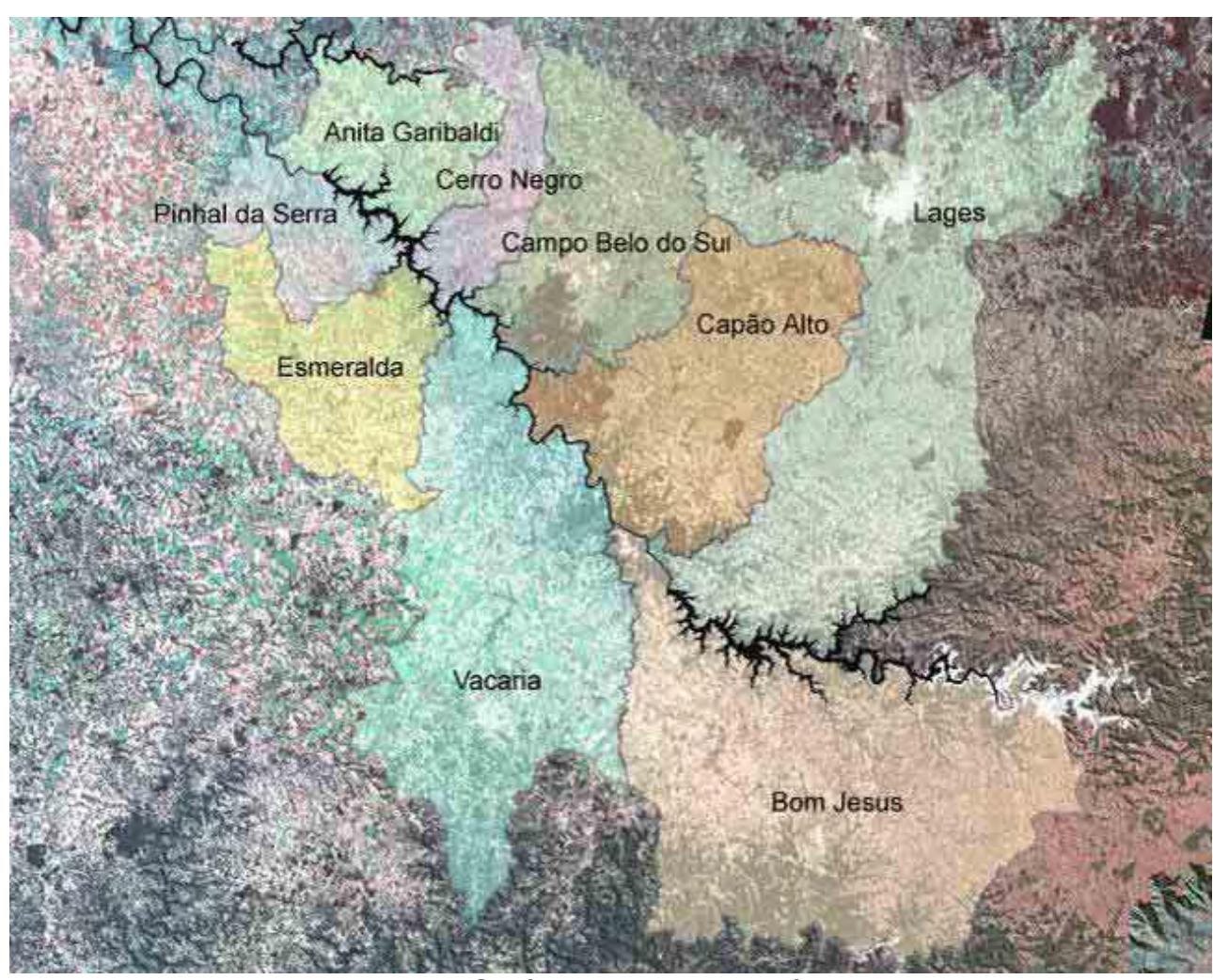

Figura 1: Imagem de Satélite com os municípios lindeiros UHE Fonte: BAESA, 2005, v.1, p.13

Já o ponto de instalação da UHE concentra-se entre os municípios de Anita Garibaldi (SC) e Pinhal da Serra (RS). Encontra-se na Bacia Hidrográfica do Rio Pelotas, portanto, apresenta característica marcante sua declividade.

A formação geológica da região impacta diretamente nas ações propostas pelos estudos, já que os vales criados a partir da ação vulcânica estabeleceram um cenário de vale com muitas rochas. Cabe destacar que a bacia encontra-se entre o Planalto dos Campos e o Planalto Dissecado do Rio Iguaçu, conforme apresentado no plano Ambiental, a ação humana deve ser planejada e sempre avaliada a partir da viabilidade de uso.

O clima da região caracteriza-se pela grande presença de umidade durante todos os anos, com temperaturas agradáveis no verão, sendo a média de $22^{\circ} \mathrm{C}$. A distribuição das chuvas permite um bom volume de água e a formação de cachoeiras. Esse cenário torna-se uma excelente oportunidade para a prática do lazer e do turismo, cabendo como alternativas: pesca, canoagem, camping, caminhadas, outros esportes radicais, banho de sol e contemplação da natureza, conforme descrito no PACUERA. 
Em função destas características e de sua formação populacional muito influenciada pelos migrantes italianos e alemães, as cidades que margeiam o reservatório têm sua economia baseada na agroindústria familiar, fruticultura, pecuária e em casos pontuais inicia-se a oferta de serviços.

Os municípios alcançados pelo reservatório apresentam certa similaridade no que se refere à sua formação, mas aos poucos são demonstradas características que poderão favorecer seu acesso à discussão do turismo. Para melhor ilustrar o trabalho essas informações são descritas as principais características de cada uma destas cidades considerando informações do IBGE - Instituto Brasileiro de Geografia e Estatística, PNUD - Programa das Nações Unidas para o Desenvolvimento, os sítios das Prefeituras Municipais e o PACUERA.

A escolha destas fontes de dados deve-se à preocupação em pensar o uso múltiplo não apenas pelo viés do turismo, mas também pela comunidade local que necessita ter prioridade tanto na determinação das estratégias para as questões socioeconômicas e culturais quanto para desfrutar dos recursos naturais disponíveis na região.

\section{Anita Garibaldi (SC)}

Situada entre os rios Canoas ao norte e o rio Pelotas ao Sul, Anita Garibaldi, possui 587,768 km² e conforme estimativa do IBGE, em 2014 a cidade possuía 8.055 habitantes (IBGE, 2014). Seu Índice de Desenvolvimento Humano dos Municípios (IDHM) 2010 é 0,688, marca ainda abaixo da média nacional (Índice de Desenvolvimento Humano - IDH de 0,744), embora retrate melhoria em relação às medições anteriores - 2000 e 1991 (Instituto de Pesquisa Econômica Aplicada - IPEA, 2010). Por se tratar de uma população formada a partir de colonos italianos, observa-se elevada influência nos hábitos alimentares, nos traços culturais e principalmente no modo de vida, neste caso, prevalecendo a prática de atividades agropecuárias.

Nas últimas décadas, com a instalação das hidrelétricas de Machadinho, Campos Novos e Barra Grande, obteve relativo desenvolvimento, visto a disponibilidade de recursos gerados por impostos, conforme informado no PCAU 
Barra Grande (BAESA, 2005). Este crescimento, portanto, exigiu a delimitação de estratégias de planejamento que poderão ser amparados pela BAESA (2005), pois neste documento já existe de forma concisa o inventário da região, inclusive com a apresentação do diagnóstico e prognóstico do município no que tange ao aproveitamento socioeconômico.

Portanto, num primeiro momento cabe especial atenção para 0 turismo, já que os instrumentos apresentados mapearam o município como tendo elevado potencial turístico tanto do ponto de vista dos eventos religiosos, tradicionais e monumentos como de suas belezas naturais, já que possui cascatas, lagoas, grutas e trilhas. Cabe destacar que potenciais precisam ser trabalhados e divulgados para então atrair um volume significativo de visitantes.

\section{Bom Jesus (SC)}

O Município de Bom Jesus foi influenciado pelos italianos e alemães, não apenas na constituição da população, mas na miscigenação da cultura catarinense e da arquitetura. Possui uma população estimada para 2014 de 2.771 habitantes ocupando uma área de 63,469 km² (IBGE, 2014). Seu índice de desenvolvimento humano (IDH-M) demonstra uma boa qualidade de vida, pois em 2010 apresentou 0,718 (IPEA, 2010). Sem dúvida este crescimento, se gradual e constante, poderá permitir a população a introdução ao debate sustentável, principalmente no que tange às questões de uso público.

O papel do destino enquanto potencial turístico deve-se à sua relevância durante o período colonial, servindo como rota dos tropeiros, festas religiosas, locais para prática e esporte radicais, despraiados, campings, hotéis fazenda, trilhas, paisagens e monumentos históricos (BAESA, 2005).

\section{Campo Belo do Sul}

A população estimada pelo IBGE, para o município de Campo Belo do Sul é de 7.358 pessoas, o que reflete uma pequena queda em relação à 2010, quando os números mostraram 7.483 habitantes. Sua densidade demográfica, torna-se consideravelmente pequena, cerca de $7,28 \mathrm{hab} . / \mathrm{km}^{2}$ uma vez que sua 
área é de 1.027,650 km² (IBGE, 2014). O IDHM 2010 foi de 0,641 representando um leve crescimento em relação aos levantamentos anteriores (IPEA, 2010).

Dentre suas principais atividades econômicas destacam-se a agricultura, principalmente a produção de kiwi, e a extração de madeira de reflorestamento. Assim como outras cidades da região, observam-se os primeiros passos para o desenvolvimento do turismo rural a partir da transformação de fazendas em pousadas. (BAESA, 2005)

Segundo inventário divulgado no PCAU, o município apresenta como potenciais turísticos as cachoeiras, fazendas, Lajeado do Martins, mirantes, lagos, grutas, monumentos históricos e festas tradicionais.

\section{Capão Alto (SC)}

De forma semelhante a campo Belo do Sul, a população de Capão Alto está reduzindo se compararmos a estimativa do IBGE para 2014 que era de $2.682 \mathrm{com}$ o as divulgadas no censo 2010 que correspondeu a 2.753 (IBGE, 2014). Embora sejam números próximos é preciso identificar quais as motivações que influenciam essa mudança de hábito e talvez como coordenar o planejamento e possibilitar a permanência da população. Talvez, o desenvolvimento de novas estratégias de trabalho possa auxiliar nesta reconstrução do espaço, já que a área da cidade é relativamente grande, cerca de 1.335,837 km² e seu IDHM em 2010 alcançou 0,654 (IPEA, 2010).

A cidade de Capão Alto, assim como as demais, mantém sua economia com base na agricultura, mas demonstra seu interesse na inovação e inserção de novas atividades como o turismo. Para tanto, algumas ações voltadas à transformação de fazendas antigas em pousadas e hotéis fazenda já estão em execução. Sua cultura prevalece a partir das tradições religiosas, como a Recomenda das Almas celebrada na Semana Santa. O destino conta ainda com atrativos naturais como grutas e cascatas (BAESA, 2005).

\section{Cerro Negro (SC)}

Cerro Negro localiza-se entre os Rios Canoas e Pelotas, tem uma área de 417,355 km² ocupados por uma população em retração que para 2014 está 
estimada em 3.417 habitantes (IBGE, 2014). Seu IDHM 2010 demonstra melhoras pontuais alcançando a marca de 0,621, o que estabelece uma relação tênue de mobilização e implantação de mudanças para a melhoria da qualidade de vida da comunidade local (IPEA, 2010).

Nesse município o turismo pode ser planejado a partir da busca pela contemplação da natureza, visitação de grutas e cascatas (BAESA, 2005). Assim como os demais destinos da região pode ser uma alternativa a implantação de hotéis fazenda.

\section{Esmeralda (RS)}

Com território de $829,766 \mathrm{~km}^{2}$, segundo informações do IBGE, Esmeralda apresenta uma população em expansão, estimada em 3.294 habitantes (IBGE, 2014). Sua população, nos últimos 20 anos tem avançado no que se refere ao IDHM alcançando em 2010, 0,680, marca inferior à média nacional, mas que representa o aumento da qualidade de vida da comunidade (IPEA, 2010).

Sua economia é movimentada pela pecuária de corte, agricultura extensiva e fruticultura, heranças da colonização italiana. Atualmente tem como principal manifestação cultural os piquetes de laçadores, organizados a partir do primeiro torneio de laço realizado na década de 1950. O destino conta ainda com festejos religiosos, monumentos históricos, cachoeiras e hotéis fazenda (BAESA, 2005).

\section{Lages (SC)}

Dos municípios lindeiros a barragem, Lages é o que apresenta maior população: cerca de 158.846 habitantes, conforme estimativa (IBGE, 2014). Essa possui elevada qualidade de vida com IDHM em 2010 de 0,770 número superior à média nacional (IPEA, 2010). Estes dados intensificam a imagem já criada pelo município, de um lugar em desenvolvimento e com muitas oportunidades. 
Mas essa importância regional é antiga, visto que no século XIX foi a capital do planalto de Santa Catarina, do ponto de vista econômico, político e cultural, conforme destacado pela BAESA (2005). Por muitos anos teve anexado os territórios de Capão Alto, Campo Belo do Sul, Cerro Negro e Anita Garibaldi.

Sua economia, embora sustentada pela pecuária, já apresenta ações concretas voltadas para o segmento de serviços, principalmente para o Turismo, já que o governo local em parceria com o estadual e federal tem desenvolvido ações propostas pelo Programa de Regionalização do Turismo. Sua vocação para o turismo rural e de eventos ganha destaque nas estratégias de planejamento e com isso poderá nortear as diretrizes dos demais municípios.

Conforme o sítio oficial da Prefeitura (2014), planejamento para a movimentação de pessoas na região conta com a utilização do aeroporto regional para voos regulares.

\section{Pinhal da Serra (RS)}

Pinhal da Serra possui área de $437,995 \mathrm{Km}^{2}$ ocupados por uma população estimada em 2.138 habitantes que por algum tempo sobreviveram basicamente da agricultura com a produção de soja, feijão, milho e alho. Conta também com a pecuária bovina, suína e em menor escala de cavalos e búfalos. A partir da construção da Usina Hidrelétrica de Barra Grande sua economia ganhou novo rumo em função das divisas geradas para o município. Conforme o portal de transparência da Prefeitura Municipal, a BAESA - Engenharia Barra Grande S/A é a principal fonte de receita.

O desenvolvimento do turismo também deve ser considerado como uma alternativa, visto que o município conta com áreas naturais propícias para a visitação de grutas, banho de cachoeira, Cânion, monumentos históricos e festejos tradicionais.

\section{Vacaria (RS)}

Conforme as estimativas do IBGE (2014), o município de Vacaria tem população correspondente a 64.564 pessoas num território de $2.124 .582 \mathrm{~km}^{2}$. Sua população apresenta boa qualidade de vida tendo IDHM em 2010 de 0,721, 
correspondendo ao $42^{\circ}$ melhor do estado, conforme Ranking dos Municípios divulgado pelo PNUD (IPEA, 2010).

De acordo com informações do sítio oficial da Prefeitura Municipal, os atrativos turísticos são o Museu Municipal, A Biblioteca Pública Municipal e o Mercado Público Municipal, contudo, o levantamento histórico cultural apresentado no Plano, destaca características ímpares como os vestígios arqueológicos de civilizações pré-históricas, proporcionando aos interessados em arqueologia um outro olhar sobre a formação da região sul. Além disso, a ocupação indígena, cabocla e posteriormente europeia - principalmente italiana, alemã e polonesa. Conforme o Plano Ambiental (BAESA, 2005), o município ainda tem como potencial turístico seus eventos e festejos tradicionais, mirantes, cachoeiras, trilhas, Cânion, fazendas e hotéis fazendas.

Portanto, uma estratégia que alie os segmentos de turismo cultural e 0 de natureza poderão ampliar o leque de ofertas para os potenciais turísticos, mas para isso será necessária uma atuação expressiva e colaborativa para a expansão da infraestrutura turística, já que até o momento a cidade conta com quatro hotéis e a formatação de pacotes para divulgação.

Proposta semelhante deverá ser desenvolvida pelos demais municípios lindeiros de forma a promover a formatação de roteiros que englobem o uso responsável da região, agregando às paisagens a possibilidade de prática de esportes aquáticos.

\subsubsection{UHE Corumbá IV}

A UHE Corumbá IV está situada na Bacia Hidrográfica do Rio Corumbá que recebe águas dos rios Alagado, Areias, Descoberto, Palmital, Anta e Capivari e abrange 7.209,21 km² estendendo-se pelos municípios goianos de "Luziânia, Novo Gama, Santo Antônio do Descoberto, Alexânia, Corumbá de

Goiás, Abadiânia, Gameleira de Goiás e Silvânia, Anápolis Águas Lindas de Goiás, Cocalzinho de Goiás, além de parte do território do Distrito Federal (WALM, 2011, p.17). Contudo, a atuação do plano restringe-se aos oito primeiros municípios, uma vez que os demais compreendem apenas regiões de nascentes. 


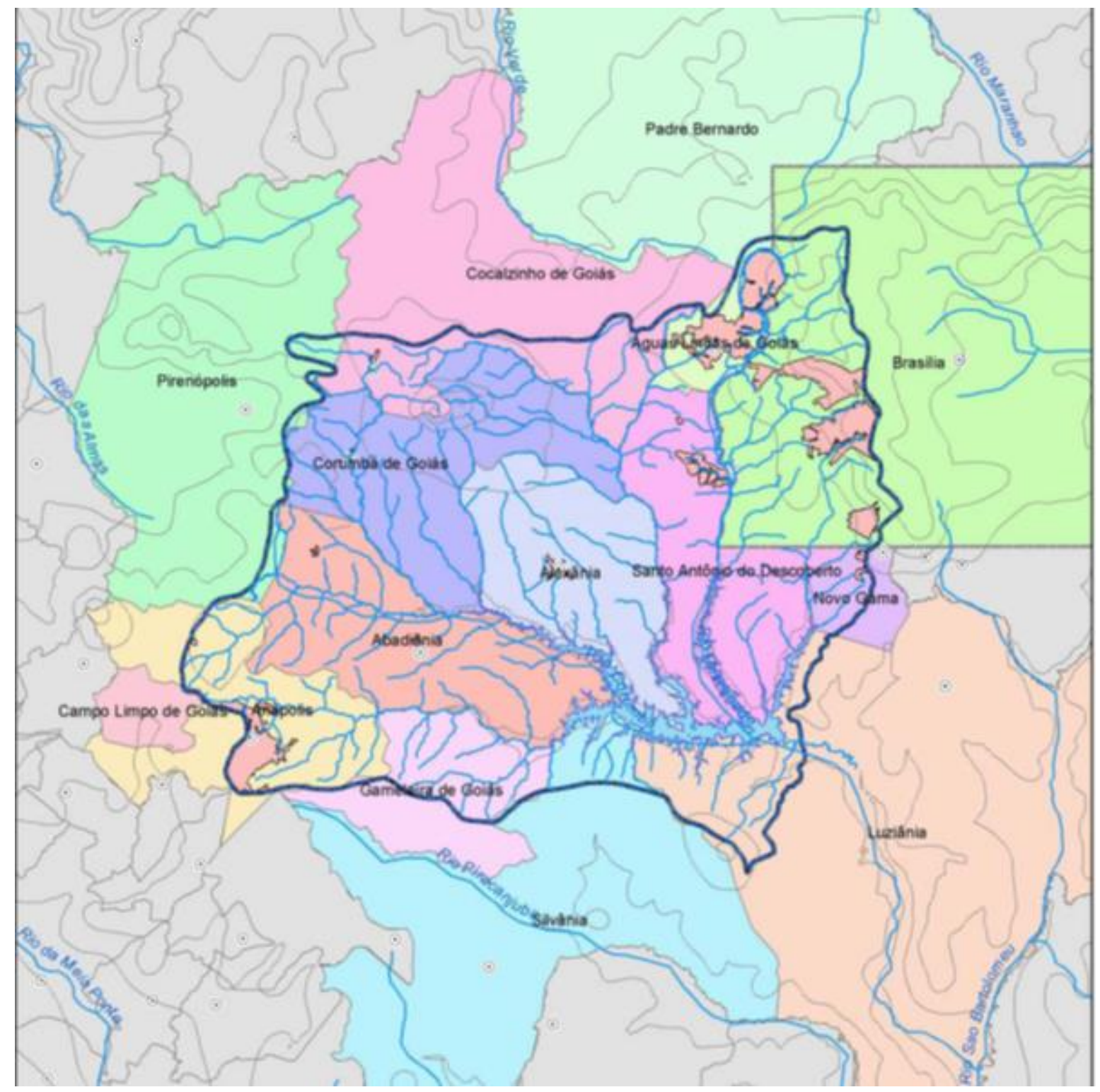

Figura 2: Bacia de Contribuição da UHE Corumbá IV

Fonte: WALM (2011)

O reservatório possui cerca de $173 \mathrm{~km}^{2}$ inundados, com profundidade média de 21 m e possui potência instalada de $127 \mathrm{MW}$ distribuídas para o Distrito Federal e região. Uma particularidade desta represa é a necessidade de atender tanto à geração de energia elétrica quanto ao abastecimento, conforme designado no processo de concessão nำ3/2000. Por esta razão, o consórcio responsável pela gestão da Corumbá IV conta com a participação da CAESB Companhia de Saneamento Ambiental do Distrito Federal, CEB - Companhia Energética de Brasília, TERRACAP - Companhia Imobiliária de Brasília e FIP/ BRB - Fundo de Pensão do Banco de Brasília.

Em termos de clima, trata-se de uma região de clima tropical com bom índice pluviométrico e temperaturas médias de $22^{\circ} \mathrm{C}$. As mudanças no tempo 
acontecem de forma rápida proporcionando sensações térmicas distintas durante o dia. Quanto ao relevo, observam-se os benefícios do planalto que permite o acesso às regiões do lago sem o comprometimento da segurança.

De acordo com o relatado no PACUERA, as comunidades tradicionais sentiam-se temerosos com a chegada da UHE, pois acreditavam que com sua chegada aumentaria o fluxo de pessoas e de certa forma este não é o objetivo de alguns grupos, por essa razão, os técnicos responsáveis respeitaram as restrições estabelecidas e apenas as que demonstraram interesse participaram das oficinas.

Após esta breve delimitação da UHE Corumbá IV acredita-se ser essencial a contextualização dos municípios atingidos pelo reservatório, conforme delimitação dada pelo PACUERA aprovado em 2011.

\section{Abadiânia}

Município goiano com altitude média de 1.000m ocupando 1.045,127 $\mathrm{Km}^{2}$ e população estimada, para 2014, de 17.701 habitantes (IBGE, 2014). Seu IDHM em 2010 é de 0,689 e expectativa de vida ao nascer de 75,5 anos (IPEA, 2010). Estes números demonstram a melhoria da qualidade de vida desta comunidade, se comparados ao levantamento anterior (2000). A base da economia do município é o turismo religioso e a agricultura, principalmente da soja.

Como atrativo turístico destaca-se a casa de Don Inácio de Loyola que recebe peregrinos nacionais e internacionais que procuram tratamentos espirituais, e a Matriz de São Pedro e São Paulo datada de 1975. De acordo com o sítio oficial da Prefeitura Municipal (2014) a principal vocação turística do Município é o turismo religioso atraído pelo Médium João de Deus.

\section{Alexânia}

Historicamente o município está atrelado à Brasília, pois seu povoamento iniciou-se a partir da construção da capital federal, localizando-se a pouco mais de $90 \mathrm{~km}$ desta sede. Sua população estimada para 2014 é de 17.701 habitantes ocupando uma $1.045,127 \mathrm{~km}^{2}$, conforme dados do IBGE 
(2014). Ao longo dos anos, observa-se a melhoria da qualidade de vida da comunidade que, de acordo com o Atlas Brasil (IPEA, 2010) divulga o avanço do IDHM do Município de 0,682, marca abaixo da média nacional, mas demonstrando crescimento contínuo e se assemelhando ao do estado.

A base da economia local concentra-se na agricultura, indústria e serviço, sendo esse o de maior relevância visto seu crescimento nos últimos anos. Para atender a este segmento de mercado, o município conta como principal atrativo o Outlet Premium Brasília e os seguintes meios de hospedagem: Raizama Fazenda Hotel, Hotel Fazenda Cabugi, Pousada Recanto dos Anjos e Hotel Bem Me Quer, conforme informações do sítio oficial da Prefeitura da cidade (2014).

Portanto, o turismo, ainda que de forma incipiente, tem alcançado espaço na pauta do cotidiano tanto dos residentes como dos gestores e planejadores que aproveitam a margem do lago para promoverem 0 desenvolvimento local e regional.

\section{Corumbá de Goiás}

Na outra margem da represa localiza-se a cidade de Corumbá de Goiás com população estimada para 2014 em 10.896 habitantes convivendo numa área de $1.061,955 \mathrm{~km}^{2}$. Sua economia baseia-se nos serviços e na agropecuária (IBGE, 2014).

Pode-se considerar que o turismo tem alcançado certo significado dentro do cotidiano da comunidade ora pelo fluxo constante de pessoas se dirigindo a Pirenópolis ${ }^{2}$ ora pela boa ocupação dos hotéis fazenda do município dos quais destaca-se o Hotel Fazenda Paraíso dos Sonhos, conforme dados do sítio oficial da Prefeitura Municipal (2014).

\section{Gameleira de Goiás}

O município de Gameleira de Goiás apresenta uma população restrita estimada para 2014 em 3.605 habitantes ocupando uma área de 591,995 km²

\footnotetext{
${ }^{2}$ Considerado pelo MTur um dos 65 destinos indutores do Turismo.
} 
(IBGE, 2014). Embora representado por um pequeno número de pessoas, o município tem demonstrado planejamento para a melhoria da qualidade de vida da população, o que se confirmou com IDHM quando atingiu 0,659 (IPEA, 2010).

Conforme informações disponibilizadas pelo sítio oficial da Prefeitura, o Município apresenta como pontos potencialmente turísticos a Praça Guilherme Veloso e a Igreja Nossa Senhora Aparecida e São Sebastião, ícone chave na construção do povoado durante a década de 1960 (WALM, 2011).

\section{Luziânia}

Fundada no século XVIII, por mineradores, Luziânia alcançou maior desenvolvimento durante a construção de Brasília e da construção das rodovias federais: BR 040 e 050. Com $3.962 \mathrm{Km}^{2}{ }^{2}$ e população estimada pelo IBGE para 2014 de 191.139 habitantes, portanto, o município mais povoado atingido diretamente pela construção de Corumbá IV. Sua economia é sustentada respectivamente por serviços de indústria e de agropecuária. A sede da UHE Corumbá IV localiza-se nesta cidade, na Fazenda Canastra, s/n.

A preocupação com o planejamento turístico é anterior à construção da UHE, pois, desde 1997 são implantadas ações voltadas para o desenvolvimento do turismo sustentável. Walm (2011) destaca como atrativos destacam-se cascata de colônia, cachoeira das três vendas, fazenda catalão, pesque-pague, piscicultura, casa da cultura Ruy Carneiro, trilha do canal da saia velha, casa do artesão, teatro municipal, festa do Divino Espírito Santo, cavalhadas de Luziânia, festa do doce de marmelo, exposição agropecuária, e outros.

\section{Novo Gama}

Município mais próximo a Brasília, o Novo Gama apresenta uma população crescente e estimada para 2014 em 104.899 habitantes ocupando a área de $194.992 \mathrm{~km}^{2}$ o que demonstra elevada densidade demográfica (IBGE, 2014). O IDHM municipal demonstra crescimento significativo na última década alcançam-no 0,684 em 2010. Sua economia sobrevive dos serviços e da indústria (IPEA, 2010). 
Embora a cidade possua um Departamento de Lazer e Turismo, não foi possível identificar no sítio oficial os atrativos turísticos, meios de hospedagem ou quaisquer outros equipamentos que possam motivar a visitação da cidade.

\section{Santo Antônio do Descoberto}

De acordo com os dados do IBGE (2014), a população estimada para 2014 de 69.000 habitantes convivendo em uma área de $944,137 \mathrm{Km}^{2}$ banhados pelo Rio Vermelho, que se encontra mais abaixo com o Rio Corumbá. Seu índice de desenvolvimento humano é de 0,665 (IPEA, 2010). A principal área de lazer da cidade é a Barragem de Descoberto situada na estrada para Cocalzinho.

\section{Silvânia}

O Município de Silvânia ocupa uma área de 2.345,940 km² com uma população estimada para 2014 em 20.106 habitantes que sobrevivem dos serviços e da agropecuária IBGE, 2014). De certa forma poucos são os direcionamentos dados para a implantação do turismo na região. 


\section{CAPÍTULO 3: O PARADIGMA DA PRÁTICA DO TURISMO A PARTIR DAS POLÍTICAS PÚBLICAS}

\subsection{PANORAMA GERAL DOS DISCURSOS}

As políticas públicas são resultados efetivos da existência de um arranjo institucional sob o qual as regras tornam-se ferramentas prioritárias na construção do planejamento e gestão das atividades desenvolvidas. Assim, ao priorizar as decisões adotadas na esfera federal observa-se a amplitude das discussões que são tomadas nas demais e, permite-se a interpretação dos cenários de forma macro, ou seja, incorporando todas as possibilidades de ação e intervenção.

Para isso, os discursos ditos e ocultos transformam-se em elementos essenciais para a construção das alternativas e interpretações. Portanto, a análise dessas falas deve pautar-se em códigos capazes de explicitar as reais intenções dos legisladores. Assim, ao analisar a documentação disponível nos sítios oficiais do Governo Federal, optou-se pela determinação de três códigos de análise: turismo, reservatório/barragem/lago, área de preservação permanente.

A partir dessa pré-seleção determinou-se os documentos prioritários que compõem os quadros (números) a seguir que apresentam a análise da Constituição Federal, leis, decretos e resoluções que, de alguma forma, trabalham com as categorias: gestão, planejamento, turismo, águas, uso múltiplo, fiscalização. Essas categorias/códigos foram determinadas a partir de informações captadas ao longo das pesquisas de gabinete e da entrevista préteste.

Para o código denominado "uso múltiplo" cabe ressaltar o entendimento dado pela autora, pois além das inúmeras opções de uso dadas à água e ao solo considera-se, ainda, as possibilidades de maximização dos benefícios, ou seja, da utilização dos espaços pela coletividade, priorizando o acesso de todos, independentemente da atividade a ser desempenhada. A única ressalva seria pelo uso racional a partir do qual todos são conscientes de seus direitos e deveres de cidadão para com o outro e com o meio ambiente. 
Quadro 1: Síntese da Constituição da República Federativa do Brasil (tópicos relevantes à essa discussão)

\begin{tabular}{|c|c|c|c|c|c|c|c|}
\hline \multicolumn{2}{|c|}{ Tipo: Constituição } & \multicolumn{6}{|c|}{ Códigos de análise } \\
\hline Ano & Assunto & Gestão & Planejamento & Turismo & Águas & Uso múltiplo & Fiscalização \\
\hline 1988 & $\begin{array}{l}\text { Constituição da } \\
\text { República } \\
\text { Federativa do } \\
\text { Brasil }\end{array}$ & Não & Não & 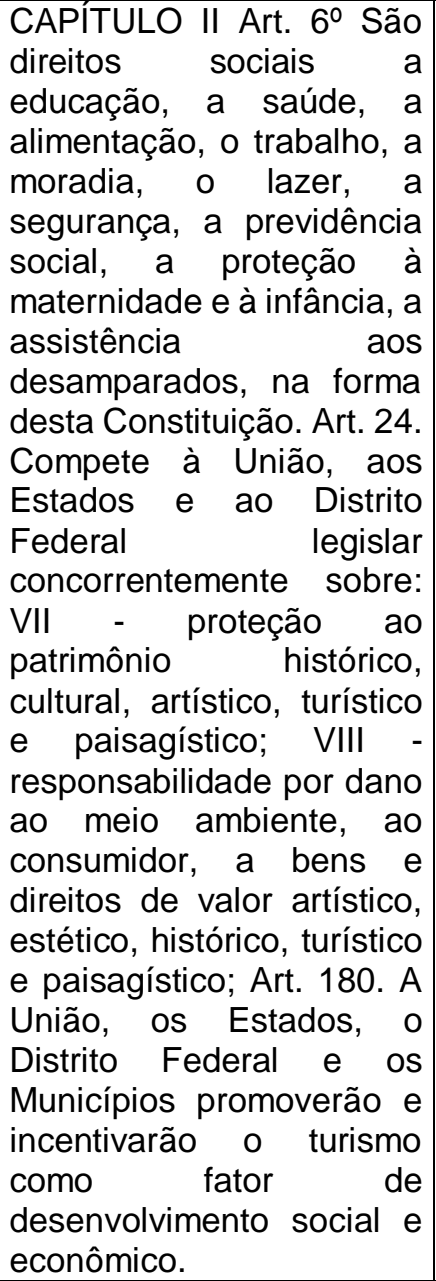 & $\begin{array}{l}\text { CAPÍTULO II Art. } 20 . \\
\text { São bens da União: III - } \\
\text { os lagos, rios e } \\
\text { quaisquer correntes de } \\
\text { água em terrenos de seu } \\
\text { domínio, ou que banhem } \\
\text { mais de um Estado, } \\
\text { sirvam de limites com } \\
\text { outros países, ou se } \\
\text { estendam a território } \\
\text { estrangeiro ou dele } \\
\text { provenham, bem como } \\
\text { os terrenos marginais e } \\
\text { as praias fluviais; } \\
\text { CAPÍTULO III Art. 26. } \\
\text { Incluem-se entre os } \\
\text { bens dos Estados: I - as } \\
\text { águas superficiais ou } \\
\text { subterrâneas, fluentes, } \\
\text { emergentes e em } \\
\text { depósito, ressalvadas, } \\
\text { neste caso, na forma da } \\
\text { lei, as decorrentes de } \\
\text { obras da União; }\end{array}$ & 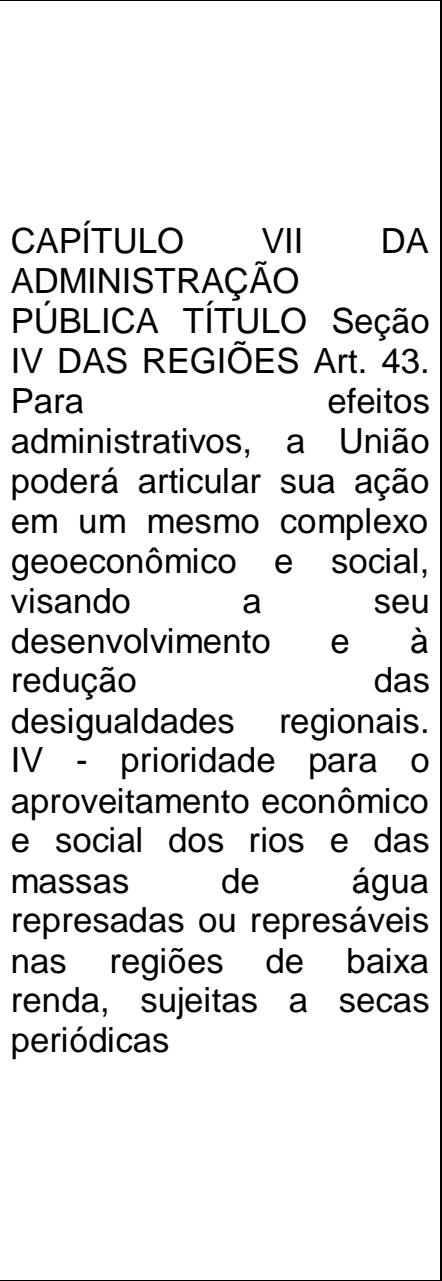 & $\begin{array}{l}\text { CAPÍTULO VI Art. } 225 . \\
\text { Todos têm direito ao meio } \\
\text { ambiente ecologicamente } \\
\text { equilibrado, bem de uso } \\
\text { comum do povo e } \\
\text { essencial à sadia } \\
\text { qualidade de vida, } \\
\text { impondo-se ao Poder } \\
\text { Público a à coletividade o } \\
\text { dever de defendê-lo e } \\
\text { preserva-lo para as } \\
\text { presentes e futuras } \\
\text { gerações. § 10 - Para } \\
\text { assegurar a efetividade } \\
\text { desse direito, incumbe ao } \\
\text { Poder Público: IV - exigir, } \\
\text { na forma da lei, para } \\
\text { instalação de obra ou } \\
\text { atividade potencialmente } \\
\text { causadora de significativa } \\
\text { degradação do meio } \\
\text { ambiente, estudo prévio } \\
\text { de impacto ambiental, a } \\
\text { que se dará publicidade; }\end{array}$ \\
\hline
\end{tabular}


Quadro 2: Síntese das principais leis vigentes que contemplam a temática do meio ambiente e do turismo

\begin{tabular}{|c|c|c|c|c|c|c|c|c|}
\hline \multicolumn{3}{|c|}{ Tipo: LEI } & \multicolumn{6}{|c|}{ CÓDIGOS DE ANÁLISE } \\
\hline $\mathbf{N}^{\circ}$ & Ano & Assunto & Gestão & Planejamento & Turismo & Águas & Uso múltiplo & Fiscalização \\
\hline 6938 & 1981 & $\begin{array}{l}\text { Política } \\
\text { Nacional de } \\
\text { Meio Ambiente }\end{array}$ & Não & $\begin{array}{|lrr|}\text { Art } 20 . & \text { III } & - \\
\text { planejamento } & & \text { e } \\
\text { fiscalização } & \text { do } & \text { uso } \\
\text { dos } & \text { recursos } \\
\text { ambientais; } & & \end{array}$ & $\begin{array}{l}\text { ANEXO VIII: atividades } \\
\text { potencialmente poluidoras } \\
\text { e utilizadoras de recursos } \\
\text { ambientais - } 19 \text { Turismo - } \\
\text { complexos turísticos e de } \\
\text { lazer, inclusive parques } \\
\text { temáticos. - Pequeno }\end{array}$ & Não & $\begin{array}{l}\text { Art. } 2^{0} \quad \text { I } \\
\text { governamental ação } \\
\text { manutenção do equilíbrio } \\
\text { ecológico, considerando o } \\
\text { meio ambiente como um } \\
\text { patrimônio público a ser } \\
\text { necessariamente } \\
\text { assegurado e protegido, } \\
\text { tendo em vista o uso } \\
\text { coletivo; }\end{array}$ & $\begin{array}{l}\text { Art. }{ }^{\circ} \mathrm{V} \text { - controle e zoneamento das } \\
\text { atividades potencial ou efetivamente } \\
\text { poluidoras; Art 9o - São instrumentos } \\
\text { da Política Nacional do Meio } \\
\text { Ambiente: IV o licenciamento e a } \\
\text { revisão de atividades efetiva ou ou } \\
\text { potencialmente poluidoras; Art.11. } \\
\text { Compete ao IBAMA propor ao } \\
\text { CONAMA normas e padrões para } \\
\text { implantação, acompanhamento e } \\
\text { fiscalização do licenciamento } \\
\text { previsto no artigo anterior, além das } \\
\text { que forem oriundas do próprio } \\
\text { CONAMA. (Redação dada pela Lei } \\
\mathrm{n}^{0} \text { 7.804, de 1989) § } 2^{0} \text { Inclui-se na } \\
\text { competência da fiscalização e } \\
\text { controle a análise de projetos de } \\
\text { entidades, públicas ou privadas, } \\
\text { objetivando a preservação ou a } \\
\text { recuperação de recursos } \\
\text { ambientais, afetados por processos } \\
\text { de exploração predatórios ou } \\
\text { poluidores. }\end{array}$ \\
\hline 9433 & 1997 & $\begin{array}{lr}\text { Política } & \\
\text { Nacional de } & \\
\text { Recursos } & \\
\text { Hídricos r e } & \\
\text { Sistema rema r de } \\
\text { Nacional de } \\
\text { Gerenciamento } \\
\text { de Recursos } \\
\text { Hídricos, }\end{array}$ & $\begin{array}{lr}\text { Títulol Capítulo I } & \text { Art. } \\
1^{\circ} \text { VI a gestão dos } \\
\text { recursos hídricos } \\
\text { dever ser } \\
\text { descentralizada } \\
\text { contar com a } \\
\text { participação r do } \\
\text { Poder Público, dos } \\
\text { usuários e das } \\
\text { comunidades }\end{array}$ & $\begin{array}{ll}\text { Capítulo III Art. } 3^{\circ} \text { IV } \\
\text { a articulação } & \text { do } \\
\text { planejamento } & \text { de } \\
\text { recursos } & \text { hídricos } \\
\text { com o dos setores } \\
\text { usuários e com os } \\
\text { planejamentos } \\
\text { regional, estadual e } \\
\text { nacional; }\end{array}$ & Não & $\begin{array}{l}\text { Título I Capítulo I Art. 10 A } \\
\text { Política Nacional de } \\
\text { Recursos Hídricos baseia-se } \\
\text { nos seguintes fundamentos: I } \\
\text { a água é um bem de domínio } \\
\text { público; II - a água é um } \\
\text { recurso natural limitado, } \\
\text { dotado de valor econômico; }\end{array}$ & $\begin{array}{l}\text { Título I Capítulo I Art. 10 IV } \\
\text { - a gestão dos recursos } \\
\text { hídricos deve sempre } \\
\text { proporcionar o uso } \\
\text { múltiplo das águas; }\end{array}$ & $\begin{array}{l}\text { Capítulo VI Art. } 29 \text { II outorgar os } \\
\text { direitos de uso de recursos hídricos, } \\
\text { e regulamentar e fiscalizar os usos, } \\
\text { na sua esfera de competência; Art. } \\
30 \text { I - outorgar os direitos de uso de } \\
\text { recursos hídricos e regulamentar e } \\
\text { fiscalizar os seus usos; }\end{array}$ \\
\hline 9984 & 2000 & $\begin{array}{l}\text { Agência } \\
\text { Nacional de } \\
\text { Águas - ANA }\end{array}$ & $\begin{array}{l}\text { Capítulo II Art. 40 XV } \\
\text { estimular a pesquisa } \\
\text { e a capacitação de } \\
\text { recursos humanos } \\
\text { para a gestão de } \\
\text { recursos hídricos; } \\
\text { XVI - prestar apoio } \\
\text { aos Estados na } \\
\text { criação de órgãos }\end{array}$ & $\begin{array}{l}\text { CapítulollArt.5ollI§ } \\
1^{\circ} \text { Aoutorga } \\
\text { preventivanão } \\
\text { confere direito de uso } \\
\text { de recursos hídricos } \\
\text { e se destina a } \\
\text { reservar a vazão } \\
\text { passível de outorga, } \\
\text { possibilitando, aos } \\
\text { investidores, } \quad \text { o } \\
\end{array}$ & Não & $\begin{array}{l}\text { CAPÍTULO II Art. 40 IV } \\
\text { outorgar, por intermédio de } \\
\text { autorização, o direito de uso } \\
\text { de recursos hídricos em } \\
\text { corpos de água de domínio } \\
\text { da União, observado o } \\
\text { disposto nos arts. 50, 60, 70 } \\
\text { e 80; }\end{array}$ & $\begin{array}{l}\text { CAPITULO II Art. } 4^{\circ} \text { XII } \\
\text { definir e fiscalizar as } \\
\text { condições de operação de } \\
\text { reservatórios por agentes } \\
\text { públicos e privados, } \\
\text { visando a garantir o uso } \\
\text { múltiplo dos recursos } \\
\text { hídricos, anforme } \\
\text { estabelecido nos planos } \\
\text { de recursos hídricos das }\end{array}$ & $\begin{array}{l}\text { CAPÍTULO II Art. } 3^{\circ} \mathrm{V} \text { - fiscalizar os } \\
\text { usos de recursos hídricos nos } \\
\text { corpos de água de domínio da } \\
\text { União; }\end{array}$ \\
\hline
\end{tabular}




\begin{tabular}{|c|c|c|c|c|c|c|c|c|}
\hline & & & $\begin{array}{l}\text { gestores de } \\
\text { recursos hídricos; }\end{array}$ & $\begin{array}{l}\text { planejamento de } \\
\text { empreendimentos } \\
\text { que necessitem } \\
\text { desses recursos. }\end{array}$ & & & $\begin{array}{l}\text { respectivas } \quad \text { bacias } \\
\text { hidrográficas; }\end{array}$ & \\
\hline 11771 & 2008 & $\begin{array}{l}\text { Política } \\
\text { Nacional de } \\
\text { Turismo }\end{array}$ & $\begin{array}{lr}\text { Capítulo II Art. } & 5^{\circ} \\
\text { XVI promover a } & \text { a } \\
\text { integração do setor } \\
\text { privado } & \text { como } \\
\text { agente } & \\
\text { complementar } & \text { de } \\
\text { financiamento } & \text { em } \\
\text { infraestrutura } & \text { e } \\
\text { serviços públicos } \\
\text { necessários r ao } \\
\text { desenvolvimento } \\
\text { turístico, }\end{array}$ & $\begin{array}{l}\text { Capítulo II Art. 5o VI } \\
\text { promover, } \\
\text { descentralizar } \\
\text { regionalizar } \\
\text { turismo, estimulando } \\
\text { Estados, Distrito } \\
\text { Federal e Municípios } \\
\text { a planejar, em seus } \\
\text { territórios, ras } \\
\text { atividades turísticas } \\
\text { de forma sustentável } \\
\text { e segura, inclusive } \\
\text { entre si, com o } \\
\text { envolvimento e a } \\
\text { efetiva participação } \\
\text { das comunidades } \\
\text { receptoras r nos } \\
\text { benefícios advindos } \\
\text { da atidade } \\
\text { econômica; }\end{array}$ & 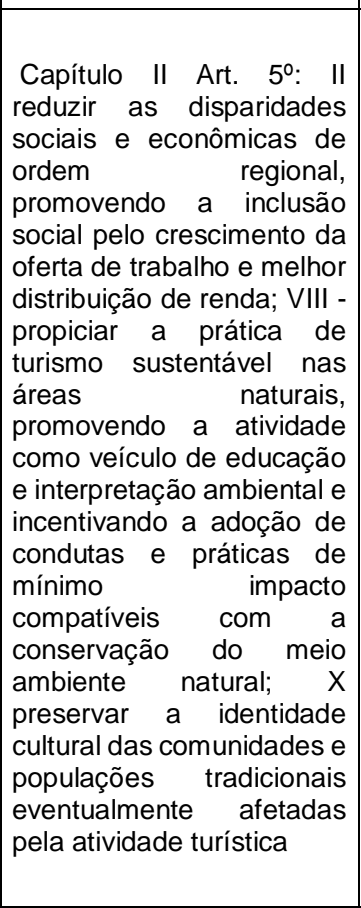 & Não & 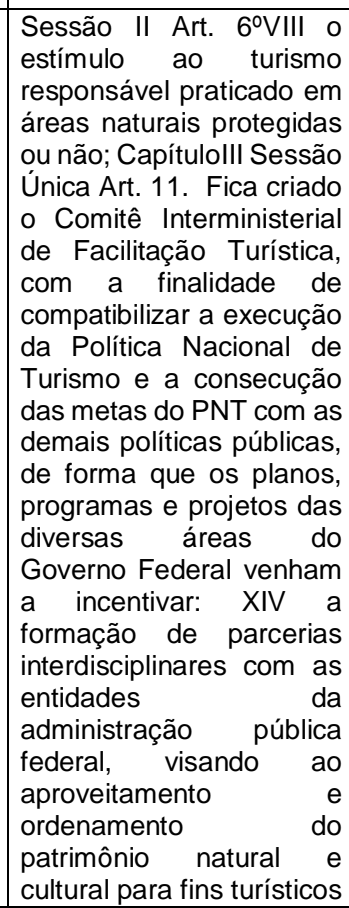 & $\begin{array}{l}\text { Capítulo I Art. 3o Caberá ao } \\
\text { Ministério do Turismo estabelecer a } \\
\text { Política Nacional de Turismo } \\
\text { planejar, fomentar, regulamentar } \\
\text { coordenar e fiscalizar a atividade } \\
\text { turística, bem como promover } \\
\text { divulgar institucionalmente o turismo } \\
\text { em âmbito nacional e internacional } \\
\text { Capítulo V -Seção II Art. } 35 \text {. } \\
\text { Ministério do Turismo, no âmbito de } \\
\text { sua competência, fiscalizará } \\
\text { cumprimento desta Lei por toda } \\
\text { qualquer pessoa, física ou jurídica } \\
\text { que exerça a atividade de prestação } \\
\text { de serviços turísticos, cadastrada ou } \\
\text { não, inclusive as que adotem, por } \\
\text { extenso ou de forma abreviada } \\
\text { expressões ou termos que possam } \\
\text { induzir em erro quanto ao real objeto } \\
\text { de suas atividades }\end{array}$ \\
\hline 12651 & 2012 & $\begin{array}{l}\text { Novo Código } \\
\text { Florestal }\end{array}$ & $\begin{array}{l}\text { Art. } 5^{\circ} \S 2^{\circ} \text { O Plano } \\
\text { Ambiental de de } \\
\text { Conservação e Uso } \\
\text { do Entorno de } \\
\text { Reservatório } \\
\text { Artificial, para os } \\
\text { empreendimentos } \\
\text { licitados a partir da } \\
\text { vigência desta Lei, } \\
\text { deverá } \quad \text { ser } \\
\text { apresentado ao } \\
\text { órgão ambiental } \\
\text { concomitantemente } \\
\text { com o Plano Básico } \\
\text { Ambiental a e } \\
\text { aprovado até o início } \\
\text { da operação do }\end{array}$ & Não & $\begin{array}{l}\text { Art. 3o IX - interesse social: } \\
\text { c) a implantação de } \\
\text { infraestrutura pública } \\
\text { destinada a esportes, lazer } \\
\text { e atividades educacionais } \\
\text { e culturais ao ar livre em } \\
\text { áreas urbanas e rurais } \\
\text { consolidadas, observadas } \\
\text { as condições } \\
\text { estabelecidas nesta Lei; c) } \\
\text { implantação de trilhas para } \\
\text { o desenvolvimento do } \\
\text { ecoturismo; XXVII - crédito } \\
\text { de carbono: título de direito } \\
\text { sobre bem intangível e } \\
\text { incorpóreo transacionável. }\end{array}$ & $\begin{array}{l}\text { Capítulo I Art. 30 Para os } \\
\text { efeitos desta Lei, entende-se } \\
\text { por: II - Área de Preservação } \\
\text { Permanente - APP: área } \\
\text { protegida, coberta ou não por } \\
\text { vegetação nativa, com a } \\
\text { função ambiental de } \\
\text { preservar os recursos } \\
\text { hídricos, a paisagem, a } \\
\text { estabilidade geológica e a } \\
\text { biodiversidade, facilitar o } \\
\text { fluxo gênico de fauna e flora, } \\
\text { protegero o solo e assegurar o } \\
\text { bem-estar das populações } \\
\text { humanas Art. 61-A. Nas } \\
\text { Áreas de Preservação } \\
\text { Permanente, é autorizada, }\end{array}$ & Não & $\begin{array}{l}\text { Art.5 } 5^{0} 1^{0} \mathrm{Na} \text { implantação de } \\
\text { reservatórios d'água artificiais de } \\
\text { que trata o caput, o empreendedor } \\
\text { no âmbito do licenciamento } \\
\text { ambiental, elaborará Plano } \\
\text { Ambiental de Conservação e Uso do } \\
\text { Entorno do Reservatório, em } \\
\text { conformidade com termo de de } \\
\text { referência expedido pelo órgão } \\
\text { competente do Sistema Nacional do } \\
\text { Meio Ambiente - Sisnama, não } \\
\text { podendo o uso exceder a 10\% (dez } \\
\text { por cento) do total da Área de } \\
\text { Preservação Permanente } \\
\text { (Redação dada pela Lei no }{ }^{\circ} 12.727 \\
\text { de 2012) }\end{array}$ \\
\hline
\end{tabular}




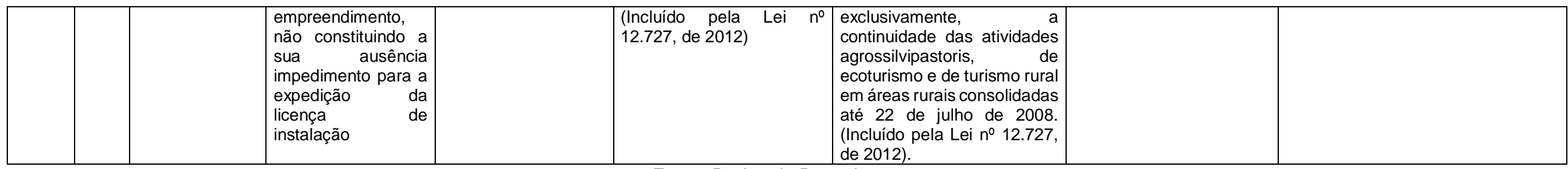

Fonte: Dados da Pesquisa

Quadro 3: Síntese do decreto que contempla a temática do meio ambiente e do turismo

\begin{tabular}{|c|c|c|c|c|c|c|c|c|}
\hline \multicolumn{9}{|c|}{ Tipo: DECRETO } \\
\hline $\mathbf{N}^{\circ}$ & Ano & Assunto & Gestão & Planejamento & Turismo & Águas & Uso múltiplo & Fiscalização \\
\hline 24643 & 1934 & $\begin{array}{l}\text { Código de } \\
\text { Águas }\end{array}$ & $\begin{array}{l}\text { Capítulo VII Art. 62. As } \\
\text { concessões ou autorizações } \\
\text { para derivação que não se } \\
\text { destine a produção de } \\
\text { energia hidro-elétrica serão } \\
\text { outorgadas pela União pelos } \\
\text { Estados ou pelos } \\
\text { municípios, conforme o seu } \\
\text { domínio sobre as águas a } \\
\text { que se referir ou conforme } \\
\text { os serviços públicos a que } \\
\text { se destine a mesma } \\
\text { derivação, de acôrdo com os } \\
\text { dispositivos deste Código e } \\
\text { as leis especiais sobre os } \\
\text { mesmo serviços; Art. } 157 . \\
\text { As concessões, para } \\
\text { produção, transmissão e } \\
\text { distribuição da energia } \\
\text { hidro-elétrica, para para } \\
\text { quaisquer fins, serão dadas } \\
\text { pelo prazo normal de } 30 \\
\text { anos. Parágrafo único. } \\
\text { Excepcionalmente, se as } \\
\text { obras e instalações, pelo } \\
\text { seu vulto, não comportarem } \\
\text { amortização do capital no } \\
\text { prazo estipulado neste } \\
\text { artigo, com o fornecimento } \\
\text { de energia por preço } \\
\text { razoável, ao consumidor, a } \\
\text { juízo do Governo, ouvidos }\end{array}$ & Não & Não & $\begin{array}{l}\text { Título III Art. 32. As } \\
\text { águas públicas de uso } \\
\text { comum ou patrimoniais, } \\
\text { dos Estados ou dos } \\
\text { Municípios, bem como } \\
\text { as águas comuns e as } \\
\text { particulares, élveos e } \\
\text { respectivos álves ser } \\
\text { margens, podem sor } \\
\text { desapropriadas pos por } \\
\text { necessidade ou por } \\
\text { utilidade pública }\end{array}$ & Não & Não \\
\hline
\end{tabular}




\begin{tabular}{|l|l|} 
os órgãos técnicos e \\
administrativos \\
competentes, a concessão \\
poderá ser outorgada por \\
prazo superior, não \\
excedente, porém, em \\
hipótese alguma, de 50 anos
\end{tabular}

Fonte: Dados da Pesquisa

Quadro 4: Síntese das resoluções CONAMA e CNRH que contemplam a temática do meio ambiente e do turismo

\begin{tabular}{|c|c|c|c|c|c|c|c|c|}
\hline $\mathbf{N}^{\circ}$ & Ano & Assunto & Gestão & Planejamento & Turismo & Águas & Uso múltiplo & Fiscalização \\
\hline 25 & 1996 & $\begin{array}{l}\text { Cria Câmara } \\
\text { Técnica } \\
\text { temporária } \\
\text { de } \\
\text { Ecoturismo }\end{array}$ & Não & Não & $\begin{array}{l}\text { Considerando o crescimento e a } \\
\text { importância do ecoturismo como } \\
\text { possível atividade econômica } \\
\text { ecologicamente sustentada; } \\
\text { Considerando a necessidade de } \\
\text { dotar o segmento de ecoturismo de } \\
\text { estrutura legal própria, harmonizada } \\
\text { com as esferas federal, estadual e } \\
\text { municipal, e de critérios e } \\
\text { parâmetros adequados, como } \\
\text { indicado nas Ações Estratégicas do } \\
\text { documento "Diretrizes para uma } \\
\text { Política Nacional de Ecoturismo", } \\
\text { produzido pelo Grupo } \\
\text { Interministerial do MICT/MMA, } \\
\text { publicado em 1994;:. Art. } 30 \text { A } \\
\text { Câmara Técnica de que trata o } \\
\text { artigo 10 desta Resolução terá como } \\
\text { objetivo contribuir com a elaboração } \\
\text { da política e a preparação de uma } \\
\text { estrutura legal própria para a área } \\
\text { de ecoturismo }\end{array}$ & Não & Não & Não \\
\hline 237 & 1997 & $\begin{array}{l}\text { Procediment } \\
\text { os e critérios } \\
\text { de utilização } \\
\text { para licença } \\
\text { ambiental }\end{array}$ & $\begin{array}{l}\text { Art. 4o Compete ao Instituto } \\
\text { Brasileiro do Meio Ambiente e } \\
\text { dos Recursos Naturais } \\
\text { Renováveis - IBAMA, órgão } \\
\text { executor do SISNAMA, o } \\
\text { licenciamento ambiental a que } \\
\text { se refere o artigo } 10 \text { da Lei } n^{\circ} \\
6.938 \text {, de } 31 \text { de agosto de } 1981 \text {, } \\
\text { de empreendimentos e e } \\
\text { atividades com signifi cativo } \\
\text { impacto ambiental de âmbito } \\
\text { nacional ou regional, a saber: II - }\end{array}$ & \begin{tabular}{|l} 
Art. 8o O Poder Público, \\
no exercício de sua \\
competência de controle, \\
expedirá as reguintes \\
licenças: I - Licença \\
Prévia (LP) - concedida \\
na fase preliminar do \\
planejamento r do \\
empreendimento ou \\
atividade aprovando sua \\
localização e concepção, \\
atestando a viabilidade \\
\end{tabular} & Não & Não & \begin{tabular}{|l|} 
Art. 10 VIII - § \\
10 \\
procedimento \\
de \\
licenciamento \\
ambiental \\
deverá constar, \\
obrigatoriament \\
e, a certidão da \\
Prefeitura \\
Municipal, \\
declarando que \\
\end{tabular} & $\begin{array}{l}\text { Art. 18. O órgão } \\
\text { ambiental competente } \\
\text { estabelecerá os prazos } \\
\text { de validade de cada tipo } \\
\text { de licença, } \\
\text { especificando-os no } \\
\text { respectivo documento, } \\
\text { levando em consideração } \\
\text { os seguintes aspectos: I- } \\
\text { O prazo de validade da } \\
\text { Licença Prévia (LP) } \\
\text { deverá ser, no mínimo, o }\end{array}$ \\
\hline
\end{tabular}




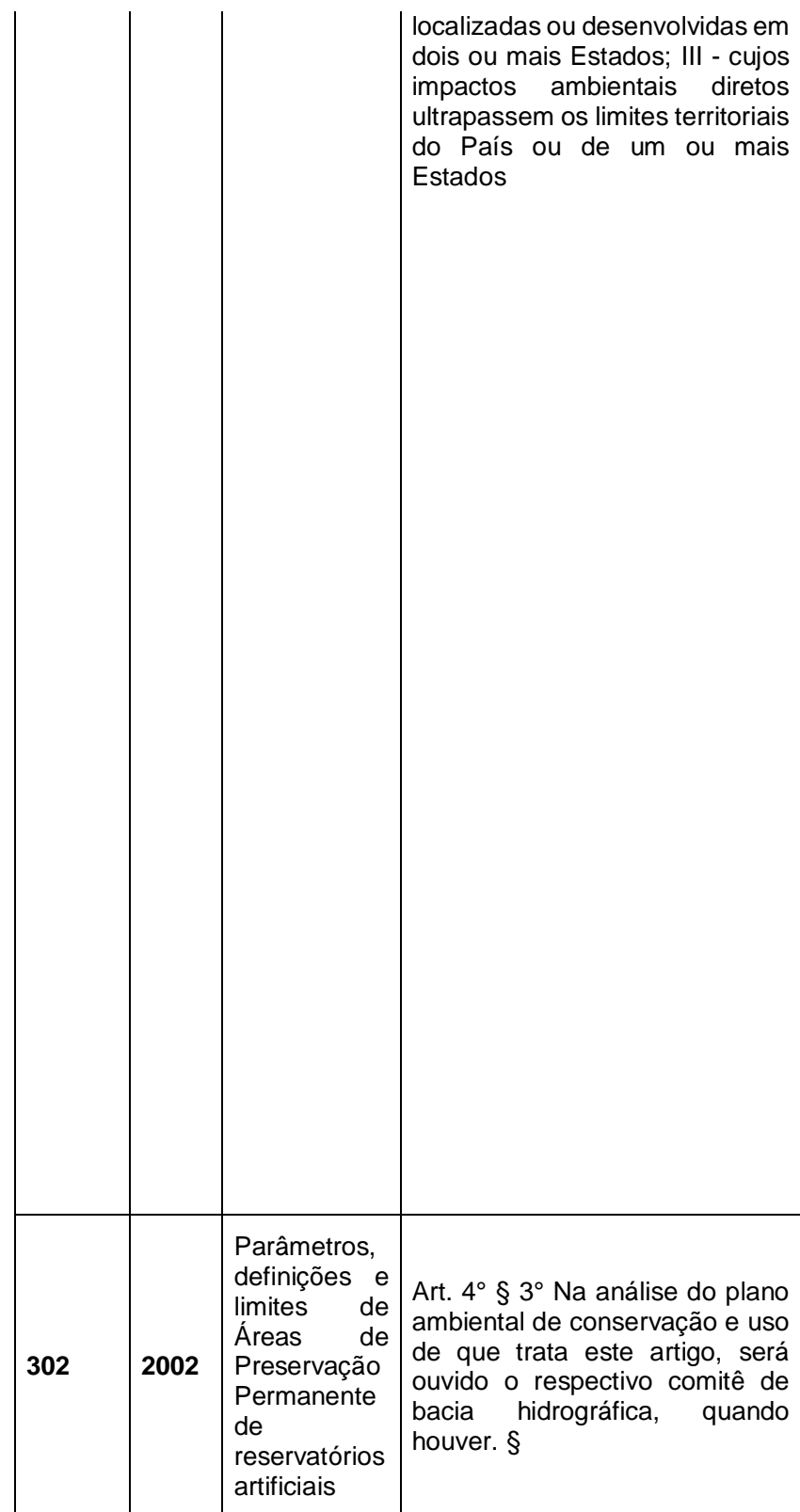

ambiental

stabelecendo

os

condicionan a

tendidos nas próximas

ases de sua implantação;

- Licença de Instalação

(LI) - autoriza a instalação

do empreendimento ou

atividade de acordo com

especificacõos

constantes dos planos,

programas e projetos

aprovados, incluindo as

medidas de controle

ambiental e demais

condicionantes, da qual

constituem

motivo

III - Licença de Operação

LO) - autoriza a operação

da atividade ou

empreendimento, após a

cumprimento eletivo

consta das licenças

anteriores, com as

medidas de controle

medidas

condicionantes

determinados para a

operação. Parágrafo

único. As licenças

ambientais poderão ser

expedidas isolada ou

sucessivamente,

acordo com a natureza

características e fase do

empreendimento

atividade.

Art $4^{\circ} \mathrm{O}$ empreendedor

âmbito

do conservação e uso poderá indicar $\begin{aligned} & \text { Art. } \\ & \text { ampliação }\end{aligned}$

áreas para impono poderá indicar ampliaça

§ $40 A$

de áreas para implantação de pólos redução do limite

licenciamento ambiental, turísticos e lazer no entorno do das Áreas

deve elaborar o plano reservatório artificial, que não Preservação

de poderão exceder a dez por cento da Permanente, a q

conservação e uso do

área total do seu entorno. § 50 As se refere o $\S$

artificial em conformidade anterior somente poderão ser estabelecida

com o termo de referência ocupadas respeitadas a legislação considerando,
- local o o tipo de cronograma

pelo

empreendiment elaboração dos planos o ou atividade programas e projetos estão em relativos

conformidade empreendimento ou com a atividade, não podendo legislação $\quad$ ser superior a 5 (cinco) aplicável ao uso anos. II - O prazo de e ocupação do validade da Licença de solo e, quando Instalação (LI) deverá for o caso, a ser, no mínimo, o autorização estabelecido pelo para supressão cronograma de de vegetação e instalação do a vulorga

a outorga para empreendimento ou o uso da água, atividade, não podendo emitidas pelos ser superior a 6 (seis) órgãos $\quad$ anos. III - O prazo de competentes. validade da Licença de Operação (LO) deverá considerar os planos de controle ambiental e será de, no mínimo, 4 (quatro) anos e, no máximo, 10 (dez) anos. seguintes conservação e uso do L - Reservatório entorno dos reservatórios

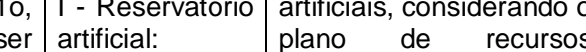
acumulação hídricos, quando houver, no não natural de sem prejuízodo 


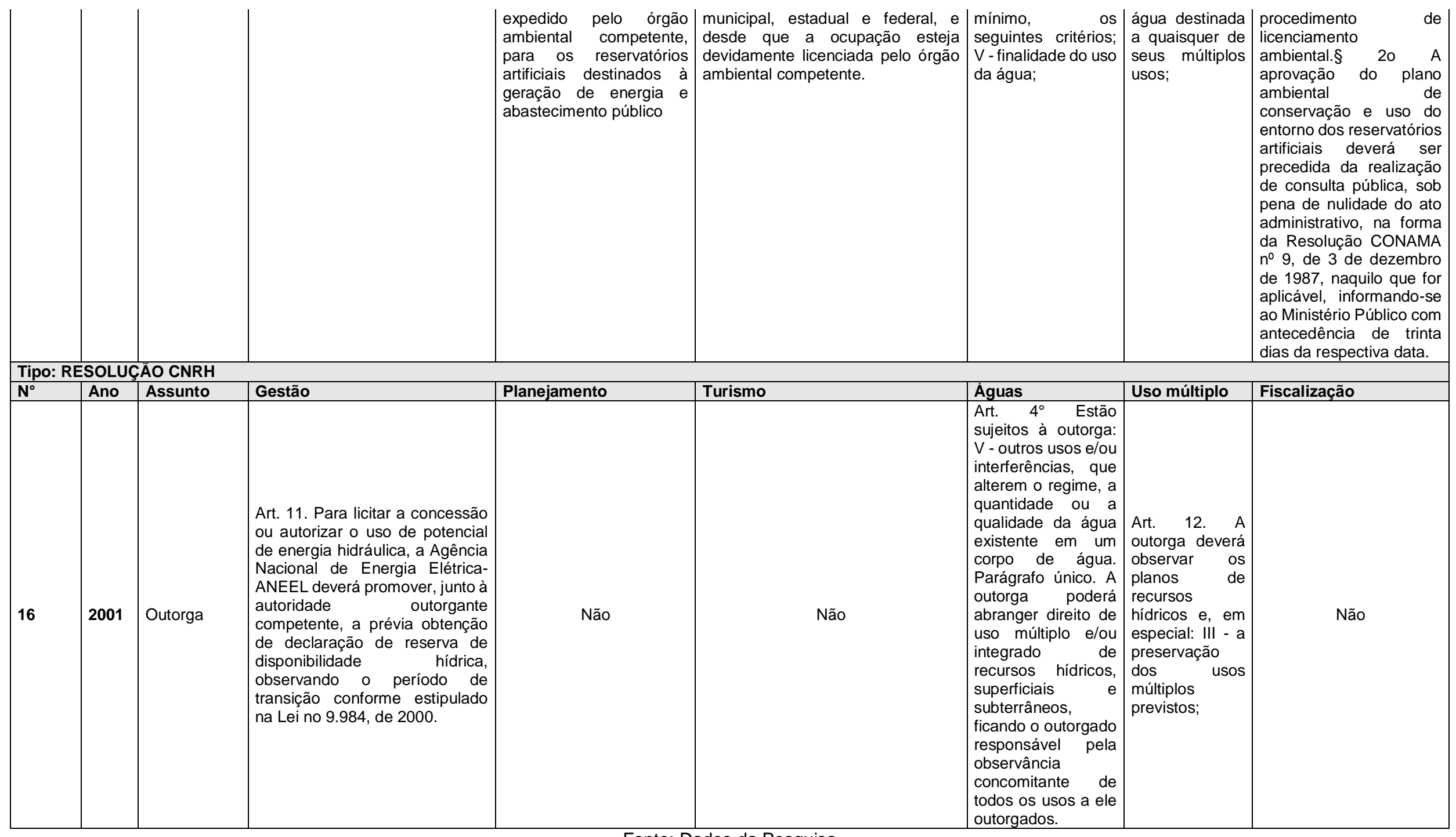

Fonte: Dados da Pesquisa 
A partir da apresentação da análise documental e comprovação dos parâmetros de análise estabelecidos, acredita-se serem pertinentes apenas algumas considerações quanto ao papel do turismo nos documentos analisados, já que, com as leituras realizadas, evidenciou-se o papel socioeconômico desse fenômeno e as contribuições que porventura poderão gerar para as comunidades envolvidas em seu planejamento e gestão. Contudo, não se deve negligenciar seu papel de poluidor, pois, os conflitos gerados durante a implantação da atividade em que, na maioria das vezes, priorizam-se os benefícios econômicos, os gestores envolvidos tendem a desconsiderar as falas dos atores sociais que, necessariamente, atuaram e atuam diariamente nesse ambiente. Já do ponto de vista ecológico, cabe a preocupação com a conservação das áreas naturais de forma a possibilitar o uso pelas atuais e futuras gerações.

Esse ponto torna-se elemento prioritário em todas as discussões que margeiam a temática do uso sustentável dos recursos naturais e das determinações jurídicas estabelecidas pelo governo federal, uma vez que, com a intensificação da crise ambiental todos os órgãos nacionais e internacionais manifestaram sua preocupação na mitigação dos conflitos a partir do reposicionamento das políticas públicas e dos discursos oficiais.

\subsection{ANÁLISE DO PROCESSO DECISÓRIO A PARTIR DA IDENTIFICAÇÃO DAS CRENÇAS}

Os cenários estabelecidos a partir da atuação conjunta do público e do privado estabelecem relações de confronto sobre o qual as ideologias determinam as escolhas dos grupos envolvidos no processo de concessão, construção e licenciamento dos empreendimentos e, com isso, fortalecem o processo decisório ampliando as incertezas que circundam os discursos.

A dialética presente nos processos decisórios que envolvem as políticas públicas ambientais e o uso múltiplo dos recursos naturais norteiam os discursos 
dos atores coletivos de forma a estereotipar grupos com posturas extremistas nos debates firmados durante a barganha existente na Câmara Federal para aprovação de novas leis ou nas audiências públicas para a aprovação do plano ambiental.

$\mathrm{Na}$ tentativa de delimitar as arenas montadas a partir da aprovação da Resolução CONAMA 302/2002, e reforçando uma das regras estabelecidas pela Lei $n^{\circ} 9.984 / 2000$ artigo $8^{\circ}$ (que estabelece a utilização de publicação oficial em pelo menos um jornal de grande circulação para o andamento das propostas de uso dos recursos hídricos), formataram-se os Quadros 5 e 6 que apresentam os principais assuntos veiculados na mídia digital, no período de 2000 a 2013, sobre as duas hidrelétricas em estudo.

A análise foi feita mediante a apropriação de parte da metodologia proposta por Sabatier (2007), pela qual é possível a identificação dos grupos de coalisão envolvidos na barganha política para aprovação dos interesses dos tomadores de decisão promovendo a mudança das políticas públicas. Cabe ressaltar que, em função dos objetivos deste trabalho, será utilizado apenas um recorte do AdvocacyCoalision Framework identificando apenas os núcleos duro, político e os aspectos institucionais.

O contexto sob o qual a UHE Barra Grande e a UHE Corumbá IV receberam a licença prévia é semelhante, pois ocorreu a partir de um momento de colapso energético sob o qual as metas governamentais pretendiam suprir as carências no fornecimento de energia. Portanto, mesmo não se tratando de uma análise comparativa, acredita-se ser relevante destacar que o processo de construção desses empreendimentos passou por momentos semelhantes de desgaste político tanto entre empresários e gestores dos órgãos ambientais e jurídicos, como entre as instituições públicas, já que os interesse e preferências superavam a interpretação da legislação vigente.

Quanto ao estabelecimento das crenças identificadas no processo de construção da UHE Barra Grande foi possível notar a preocupação do IBAMA com a sustentabilidade ambiental da região, utilizada para a construção das 
UHE, assim como a atuação constante do Ministério Público no monitoramento das ações dos empresários no que tange ao cumprimento da legislação e dos acordos com a comunidade atingida. Por se tratar de projeto com alguns equívocos nos estudos preliminares, observou-se que apesar da necessidade de preservação do bioma Mata Atlântica ser prioridade legal, ainda assim as perdas de faixas extensas de mata de araucária ficaram como o prejuízo gerado pela construção desse empreendimento. Inicialmente não foram identificadas quaisquer falas relacionadas à utilização da região para o turismo nas reportagens analisadas.

A participação da comunidade, em alguns momentos, é retratada a partir das ações do Movimento dos Atingidos por Barragem (MAB). Contudo não são observadas falas relacionadas à percepção individual local quanto às implicações que ocorreriam desde a criação do empreendimento e de seu usufruto ao longo dos anos. Observa-se de forma indireta a resistência de grupos pequenos de moradores que não aceitaram os valores propostos para 0 pagamento das terras desapropriadas. Acredita-se que as audiências públicas concentraram interesses de parte dos residentes que não possuíam liderança sobre todos os grupos de moradores.

O Quadro 5 sintetiza as crenças identificadas nos núcleos duros, políticos e os aspectos institucionais. Cabe destacar que para essa identificação foram estabelecidos códigos de análise como: visão sobre o meio ambiente e comunidade; visão sobre o turismo; visão geral sobre o projeto; níveis de competência; tipos de prioridade; decisões participativas; poder de barganha; marco legal; e instituições envolvidas.

Quadro 5: UHE Barra Grande - estrutura hierárquica das crenças

\begin{tabular}{|c|l|}
\hline Núcleo Duro & \multicolumn{1}{c|}{ Crenças } \\
\hline \multirow{4}{*}{\begin{tabular}{c} 
Visão sobre o meio $\begin{array}{c}\text { ambiente } \mathbf{e} \\
\text { comunidade } \\
\text { atingida }\end{array}$ \\
\cline { 2 - 2 }
\end{tabular}} & IBAMA exige mais informações e documentos \\
\cline { 2 - 2 } & Danos Ambientais \\
\cline { 2 - 2 } & Aumento dos custos do projeto \\
\cline { 2 - 2 } & Comprometimento da oxigenação das águas \\
\cline { 2 - 2 } & Inclusão socioprodutiva na construção da barragem \\
\hline
\end{tabular}




\begin{tabular}{|c|c|}
\hline & $\begin{array}{l}\text { Tensão nas negociações com o Movimento dos Atingidos por Barragem } \\
\text { - MAB } \\
\text { Agricultores e ambientalistas entram na justiça pela continuidade da } \\
\text { Floresta de Araucária }\end{array}$ \\
\hline \multirow{7}{*}{$\begin{array}{l}\text { Visão geral sobre o } \\
\text { projeto }\end{array}$} & Captação de recursos \\
\hline & Consórcio com empresas de alumínio \\
\hline & Assinatura de Termo de Ajuste de Conduta \\
\hline & Aumento dos custos do projeto - compensação ambiental \\
\hline & Licenciamento ambiental \\
\hline & Desmatamento e remoção de proprietários \\
\hline & $\begin{array}{l}\text { Mudança do grupo gestor } \\
\text { Ibama e Ministério Público apontam lacunas no projeto ao Ministério do } \\
\text { Meio Ambiente }\end{array}$ \\
\hline Núcleo Político & Crenças \\
\hline \multirow{4}{*}{$\begin{array}{l}\text { Níveis de } \\
\text { Competência }\end{array}$} & $\begin{array}{l}\text { IBAMA é responsável pelo licenciamento ambiental } \\
\begin{array}{l}\text { MAB defende proprietários pedindo à justiça que impeça } 0 \\
\text { desmatamento }\end{array}\end{array}$ \\
\hline & MAB pede aumento nas indenizações \\
\hline & Polícia Federal apura competências na aprovação do EIA/RIMA \\
\hline & Ibama é responsável por multa ambiental \\
\hline \multirow{2}{*}{$\begin{array}{c}\text { Decisões } \\
\text { participativas }\end{array}$} & Organizações não Governamentais \\
\hline & Movimento dos atingidos por barragem \\
\hline \multirow{12}{*}{ Poder de barganha } & $\begin{array}{l}\text { Governo Federal anuncia início da construção de Barra Grande } \\
\text { Governo Federal em parceria com BNDES disponibiliza recursos } \\
\text { financeiros }\end{array}$ \\
\hline & Companhia de Alumínio amplia investimentos \\
\hline & $\begin{array}{l}\text { Acordo entre Ministério de Minas e Energia e Meio ambiente para } \\
\text { viabilizar licenciamento }\end{array}$ \\
\hline & Entraves no licenciamento ambiental \\
\hline & Mudanças nas regras de licenciamento para viabilizar investimentos \\
\hline & Previsão de nova crise energética \\
\hline & IBAMA é questionado sobre atrasos em licenciamentos \\
\hline & $\begin{array}{l}\text { Liberação de licença ambiental } \\
\text { Divergência de interesse entre os ministérios de Minas e Energia, Meio } \\
\text { Ambiente e Casa Civil }\end{array}$ \\
\hline & $\begin{array}{l}\text { Casa Civil intermedia negociações } \\
\text { Organizações não Governamentais entram na justiça para proteger } \\
\text { floresta de araucária }\end{array}$ \\
\hline & Ibama mantem rigidez para licenciamento \\
\hline & Investigação em concessão de licença \\
\hline & $\begin{array}{l}\text { Força do setor hidrelétrico } \\
\text { Ministério de Minas e Energia apoia queixas de investidores sobre } \\
\text { condicionantes se transformarem em embargo } \\
\text { Associação Brasileira dos Investidores em Autoprodução de Energia } \\
\text { Elétrica (Abiape) exime investidores de culpa pelos problemas com } \\
\text { licenciamento }\end{array}$ \\
\hline
\end{tabular}




\begin{tabular}{|c|c|}
\hline & $\begin{array}{l}\text { Ministério do Meio ambiente é considerado derrotado após derrubada } \\
\text { de floresta }\end{array}$ \\
\hline & Ministério Público e governo assinam termo de compromisso \\
\hline & Tribunal regional Federal suspende liminar \\
\hline & MAB cria tumulto em escritório da Concessionária \\
\hline & Militante do MAB são presos \\
\hline & Empreendedores sentem-se ameaçados pelo MAB \\
\hline $\begin{array}{c}\text { Aspectos } \\
\text { institucionais }\end{array}$ & Crenças \\
\hline \multirow[b]{2}{*}{ Marco legal } & Lei da Mata Atlântica \\
\hline & $\begin{array}{l}\text { Mudança de regras para as distribuidoras de energia investirem em } \\
\text { geração }\end{array}$ \\
\hline \multirow{13}{*}{$\begin{array}{l}\text { Instituição } \\
\text { envolvidas }\end{array}$} & Advocacia Geral da União \\
\hline & Alcan \\
\hline & ALCOA \\
\hline & $\begin{array}{l}\text { Associação que representa as concessionárias de distribuição no país, } \\
\text { a Abradee }\end{array}$ \\
\hline & BNDES \\
\hline & Bradesco \\
\hline & Camargo Correia \\
\hline & Miriam Prochnow \\
\hline & Movimento dos Atingidos por Barragens (MAB) \\
\hline & Rede de ONGs da Mata Atlântica \\
\hline & The NatureConservancy \\
\hline & Votorantim \\
\hline & WWF \\
\hline
\end{tabular}

Fonte: Dados da Pesquisa

A UHE Corumbá IV apresenta cenários de barganha próximos à de Barra Grande, contudo sofreu pouca intervenção de ONGs - Organizações não Governamentais e do Movimento dos Atingidos por Barragem (MAB), talvez por sua dimensão e pelo número de pessoas impactadas, ou seja, cerca de 117 famílias conforme informado pela BAESA (2005). Cabe destacar que os impasses políticos foram determinantes nas arenas de discussão já que este empreendimento movimentou diretamente esforços do governo do Distrito Federal (DF) que, à época, também enfrentava crise de abastecimento. Neste caso, para todos os códigos estabelecidos foram identificadas as crenças. 
Durante a análise de aproximadamente 270 reportagens veiculadas por exemplo na Gazeta Mercantil, Jornal do Brasil, Correio Braziliense, Estado de São Paulo, Valor Econômico, Folha de São Paulo, O Globo, dentre outros, identificou-se que embora tenha sofrido perdas irreparáveis com a inundação da área da barragem, ainda assim, o meio ambiente teve alguns ganhos quanto à criação das estações de tratamento de esgoto, indispensáveis para a utilização das águas da bacia do Rio Corumbá que se encontravam poluídas e impróprias para o consumo humano.

Para o turismo, objeto deste estudo, observaram-se discursos a favor de seu uso como uma oportunidade de desenvolvimento e, consequentemente, uma alternativa para a melhoria da qualidade de vida da população residente e do entorno, já que as estruturas atenderiam diretamente aos habitantes do Distrito Federal. Mas, em alguns momentos, a comunidade demonstrou resistência a essa prática por identificar sua correlação com a especulação imobiliária. Nas reportagens, identifica-se o surgimento de loteamentos para condomínios de segunda residência que aqueceram o mercado imobiliário das cidades que margeiam o lago.

No Quadro 6 são apresentados os resultados das análises feitas a partir da leitura e interpretação das reportagens que veicularam durante o processo de construção e implantação da UHE Corumbá IV, visto que, para se entender o processo político que envolve a construção das crenças, é necessário acompanhar como são mantidas as ideologias dos grupos de interesse e dos atores principais.

Quadro 6: UHE Corumbá IV - estrutura hierárquica das crenças

\begin{tabular}{|c|l|}
\hline Núcleo Duro & \multicolumn{1}{c|}{ Crenças } \\
\hline \multirow{4}{*}{$\begin{array}{c}\text { Visão sobre o } \\
\text { meio ambiente e } \\
\text { comunidade } \\
\text { atingida }\end{array}$} & Danos ambientais \\
\cline { 2 - 3 } & Despoluição das águas que recebem esgoto do DF e GO \\
\cline { 2 - 3 } & Desapropriação, remoção de famílias e pagamento de indenizações \\
\cline { 2 - 3 } & Licenciamento ambiental \\
\cline { 2 - 2 } & Intervenção do Ministério Público \\
\cline { 2 - 2 } & Degradação de rios e nascentes \\
\hline
\end{tabular}




\begin{tabular}{|c|c|}
\hline & Atribuição de responsabilidades à sociedade \\
\hline & Comunidade atingida alega não ter sido ouvida \\
\hline & Área de construção da UHE é considerada de utilidade pública \\
\hline & Melhoria da qualidade de vida do entorno e de Brasília \\
\hline & $\begin{array}{l}\text { Maior aproximação dos municípios da RIDE - Região Integrada de } \\
\text { Desenvolvimento do Distrito Federal e Entorno }\end{array}$ \\
\hline & Inclusão socioprodutiva na construção da barragem \\
\hline & Permanência de poucos trabalhadores após a inauguração \\
\hline & Loteamento e valorização das terras \\
\hline & Desmatamento e resgate da fauna \\
\hline & Uso racional dos recursos naturais \\
\hline & Parceria entre DF e GO \\
\hline & Ocupação desordenada ameaça reservatório \\
\hline & Problemas relacionados à saúde pública \\
\hline & Segurança hídrica para o DF \\
\hline & Pagamento de royalties \\
\hline \multirow{7}{*}{$\begin{array}{l}\text { Visão sobre o } \\
\text { turismo }\end{array}$} & Especulação imobiliária \\
\hline & Pólo turístico \\
\hline & Infraestrutura turística \\
\hline & Resgate dos patrimônios arqueológicos e materiais \\
\hline & Turismo religioso \\
\hline & Desenvolvimento dos municípios \\
\hline & Atividades como Jet skie lancha podem comprometer a qualidade da água \\
\hline \multirow{18}{*}{$\begin{array}{l}\text { Visão geral } \\
\text { sobre o projeto }\end{array}$} & Melhoria da qualidade de vida \\
\hline & Especulação imobiliária \\
\hline & Resistência do Ministério Público e dos ambientalistas \\
\hline & Desenvolvimento econômico \\
\hline & Solução para problemas de abastecimento \\
\hline & Absorção de mão de obra \\
\hline & Atrasos e pedidos de prorrogação de prazo para inauguração \\
\hline & Mudança do grupo gestor \\
\hline & Projeto multiuso \\
\hline & Captação de recursos financeiros \\
\hline & Mudança de órgão regulador \\
\hline & Promoção de projetos culturais, sociais e ambientais \\
\hline & Problema técnicos \\
\hline & Auto custo do projeto \\
\hline & Problemas ambientais \\
\hline & Captação de água \\
\hline & Projeto prioritário para o Governo Federal \\
\hline & Endividamento \\
\hline
\end{tabular}




\begin{tabular}{|c|c|}
\hline Núcleo Político & Crença \\
\hline \multirow{23}{*}{$\begin{array}{l}\text { Níveis de } \\
\text { Competência }\end{array}$} & O reservatório fica em território goiano \\
\hline & Agencia Goiana de meio Ambiente é responsável pelos licenciamentos \\
\hline & Corumbá Concessões é responsável pela proteção do meio ambiente \\
\hline & $\begin{array}{l}\text { ANEEL não deixa clara as responsabilidades para minimizar impactos } \\
\text { negativos }\end{array}$ \\
\hline & $\begin{array}{l}\text { ANEEL estabelece prazo para conclusão do empreendimento } \\
\text { Agência Goiana de Meio Ambiente acredita que a questão da água deve } \\
\text { passar pelo IBAMA }\end{array}$ \\
\hline & Ministério Público pede que IBAMA assuma o processo de licenciamento \\
\hline & ANEEL questiona investimentos de distribuidora \\
\hline & $\begin{array}{l}\text { Ficais do DF são insuficientes para minimizar os problemas de poluição } \\
\text { Demanda de criação do Sistema Integrado de Vigilância, Preservação e } \\
\text { Conservação de Mananciais do DF }\end{array}$ \\
\hline & Bamaco do Brasil torna-se credor \\
\hline & Governo do DF e de GO acompanham o andamento da obra \\
\hline & Ibama exige maiores informações e o desenvolvimento de ações \\
\hline & Ibama concede licença de instalação \\
\hline & Ibama periodicamente faz vistorias técnicas \\
\hline & Ministério de Minas e Energia acompanha o andamento do projeto \\
\hline & Tribunal de Goiás autoriza enchimento parcial do lago \\
\hline & Ministério Público e IBAMA questionam enchimento parcial do lago \\
\hline & Corumbá IV recorre contra determinações de IBAMA \\
\hline & CEB é acionista do consorcio \\
\hline & ANEEL autoriza operação em carga total \\
\hline & CAESBE trata de esgoto e saneamento ambiental em Corumbá IV \\
\hline & $\begin{array}{l}\text { Investidores do DF são responsáveis po mais de } 70 \% \text { dos recursos } \\
\text { financeiros }\end{array}$ \\
\hline & CEB é responsável pela distribuição e enfrenta problemas \\
\hline & $\begin{array}{l}\text { Serving é acionista controlador e empresa contratada para executar } \\
\text { serviços }\end{array}$ \\
\hline \multirow{9}{*}{$\begin{array}{l}\text { Tipos de } \\
\text { prioridade }\end{array}$} & Despoluição do Rio \\
\hline & Abastecimento do DF \\
\hline & Aumento da oferta de energia \\
\hline & $\begin{array}{l}\text { IBAMA sugere venda de concessões mediante discussões públicas } \\
\begin{array}{l}\text { Fracionamento da Companhia Energética de Brasília (CEB) em várias } \\
\text { subsidiárias }\end{array}\end{array}$ \\
\hline & $\begin{array}{l}\text { Corumbá Concessões precisa de agilidade para construção e enchimento } \\
\text { do lago }\end{array}$ \\
\hline & Pagamento de indenização e realocação da população \\
\hline & Obra deverá ser fiscalizada periodicamente \\
\hline & Melhoria da qualidade de vida e redução das desigualdades \\
\hline & $\begin{array}{l}\text { Cumprimento de Termo de Ajuste de Conduta } \\
\begin{array}{l}\text { Corumbá Concessões precisa de agilidade para construção e enchimento } \\
\text { do lago }\end{array}\end{array}$ \\
\hline
\end{tabular}




\begin{tabular}{|c|c|}
\hline & Saúde dos moradores de área rural \\
\hline & Ampliação no abastecimento \\
\hline \multirow{3}{*}{ Participação } & Moradores a favor e contra a construção do empreendimento \\
\hline & Governadores do DF e de GO encabeçam as discussões \\
\hline & $\begin{array}{l}\text { Ministério Público trabalha em conjunto para garantir benefícios sociais e } \\
\text { ambientais }\end{array}$ \\
\hline \multirow{20}{*}{$\begin{array}{l}\text { Poder de } \\
\text { barganha }\end{array}$} & $\begin{array}{l}\text { Governo do DF se empenha na construção de Corumbá IV e articula } \\
\text { negociações }\end{array}$ \\
\hline & Governo do DF consegue o financiamento de parte do recurso \\
\hline & $\begin{array}{l}\text { ANEEL inicialmente aprova fornecimento de energia mas a barragem } \\
\text { também servirá para abastecimento }\end{array}$ \\
\hline & Negociação dos valores de indenização \\
\hline & $\begin{array}{l}\text { Empresários financiadores de UHEs e empreiteiros buscam apoio do } \\
\text { Governo Federal por agilidade nos licenciamentos }\end{array}$ \\
\hline & Obras de energia tornam-se prioridade para Governo federal \\
\hline & Redução das desigualdades torna-se prioridade \\
\hline & Impasses entre os Ministério de Minas e Energia e do Meio Ambiente \\
\hline & Liberação de licenças pelo IBAMA \\
\hline & $\begin{array}{l}\text { Ministério Público trabalha em conjunto para garantir benefícios sociais e } \\
\text { ambientais }\end{array}$ \\
\hline & $\begin{array}{l}\text { Governo do DF tem dificuldade de aprovação, pela Câmara Legislativa, de } \\
\text { novos recursos e parcerias }\end{array}$ \\
\hline & $\begin{array}{l}\text { Parlamentares sedem e autorizam a inclusão da CAESB e BRB como } \\
\text { acionista de CorumbálV }\end{array}$ \\
\hline & $\begin{array}{l}\text { Governo do DF tem dificuldade de aprovação, pela Câmara Legislativa, de } \\
\text { novos recursos e parcerias }\end{array}$ \\
\hline & Ministério Público exige cumprimento de Termo de Ajuste de Conduta \\
\hline & Mudança política e de gestão dos investimentos pelo DF \\
\hline & Crise financeira em órgãos acionistas \\
\hline & \begin{tabular}{|l}
$\begin{array}{l}\text { Governo Federal não consegue a implantação de } \\
\text { empreendimentos leiloados }\end{array}$ \\
\end{tabular} \\
\hline & Mudança política e de gestão dos investimentos pelo DF \\
\hline & $\begin{array}{l}\begin{array}{l}\text { Serving-Civilsan assume investimentos e promove mudanças na } \\
\text { composição acionária }\end{array} \\
\end{array}$ \\
\hline & $\begin{array}{l}\text { Necessidade de investimentos na rede de distribuição } \\
\text { Ministério Público avalia investimentos e participações na construção de } \\
\text { Corumbá IV }\end{array}$ \\
\hline $\begin{array}{c}\text { Aspectos } \\
\text { institucionais }\end{array}$ & Crença \\
\hline Marco legal & Licenciamento Ambiental \\
\hline \multirow{6}{*}{$\begin{array}{l}\text { Instituição } \\
\text { envolvidas }\end{array}$} & Governo do DF \\
\hline & CAESB \\
\hline & ANEEL \\
\hline & Associação dos Pequenos Produtores Rurais \\
\hline & Agência Goiana de Meio Ambiente e Recursos Naturais \\
\hline & Governo de Goiás \\
\hline
\end{tabular}


CEB

VIA Engenharia

CTE - Centro Tecnológico de Engenharia Ltda

Ministério Público de Goiás

Saneamento de Goiás S.A. (Saneago)

Secretarias de Meio Ambiente e de Recursos Hídricos do DF

Instituto Brasileiro do Meio Ambiente e Recursos Naturais Renováveis (Ibama)

Ministério Público Federal

Governo Federal

Câmara Legislativa do DF

Fonte: Dados da Pesquisa

Por fim, a crítica a partir da estrutura proposta por Sabatier (1993) permitiu o entendimento do processo decisório de forma diferenciada das demais metodologias de análise, pois foi possível conhecer todas as arestas existentes nos discursos tanto dos grupos interessados na construção dos empreendimentos, afirmando seu interesse no desenvolvimento econômico e social das regiões em tese com poucas oportunidades de ascensão, como dos grupos responsáveis pela preservação e conservação do meio ambiente natural, que em muitos casos são vistos como os responsáveis por impedir o crescimento do país sob a plataforma da relevância da natureza para a continuidade da vida. Existem, ainda, grupos menores que buscam defender os interesses das comunidades atingidas buscando maximizar seus benefícios. A este grupo são comuns rótulos de manifestantes, pois para alcançar seus objetivos, frequentemente organizam ações em prol de suas bandeiras.

\subsection{CONTRIBUIÇÕES DADAS PELOS PRINCIPAIS ATORES}

O processo de aprovação, licenciamento e construção de hidrelétricas possui um arcabouço legal capaz de controlar o comportamento dos grupos responsáveis pelos debates a favor e contra o uso das águas para 0 fornecimento de energia limpa. Porém, muitas vezes observa-se que, apesar de promover o diálogo entre o público e o privado, ainda não é capaz de uniformizar as informações entre os órgãos públicos, causando, neste caso, conflitos de 
competência e, de certa forma, ignorância quanto às ações em desenvolvimento. De modo semelhante, as comunidades também ficam à margem quanto ao seu papel decisório nas questões correlatas à temática ambiental, pois, ao se organizarem poderiam alcançar benefícios reais capazes de promover a melhoria da qualidade de vida da coletividade e não apenas de grupos isolados, como ocorre com frequência.

Para aprofundar nestas discussões e compreender como os principais atores visualizam o processo de uso dos lagos para o turismo, foi necessário recorrer às atas das audiências públicas da UHE Barra Grande e de reuniões realizadas pela Corumbá Concessões.

A partir da leitura e análise desses documentos estabeleceu-se a existência de três atores: a) Poder Público (Câmara Legislativa Estadual, Prefeituras e Órgãos Ambientais Estaduais e Federal); b) UHE; e c) os Atingidos pela Barragem (MAB, sindicatos e associações de trabalhadores). Esses atores apresentaram suas ideias e demandas no decorrer da construção e aprovação dos PACUERA/PCAU considerando a finalidade desse instrumento como sendo disciplinar o uso do entorno do reservatório.

Desta forma, tem-se o poder público focado no desenvolvimento regional priorizando ações capazes de promover o social e beneficiar a coletividade, trazendo não apenas o pagamento das indenizações, mas também o acesso ao lago como fator de crescimento econômico pelo uso do turismo. Nesse caso, são frequentes as sugestões de criação de Unidades de Conservação.

A comunidade, por sua vez, reivindica a negociação e o pagamento das indenizações a partir de preços justos, o reassentamento coletivo, possibilitando a manutenção dos laços de vida, o acesso ao lazer e ações que permitam a piscicultura, ou seja, não apresenta preocupação imediata com a utilização do lago e de seu entorno para o desenvolvimento do turismo, talvez por saber que para isso seria necessário o dispêndio de recursos financeiros na criação de infraestrutura. Certamente esses recursos poderiam, em parte, ser financiados 
pelas prefeituras, mas, caso contemplados pelo Plano Diretor, o montante final ficaria a cargo do empreendedor.

Já os representantes das usinas hidrelétricas manifestam-se sobre a viabilidade do projeto e os benefícios que proporcionarão à comunidade. Ressaltam os pagamentos de indenizações a partir de negociações por grupos, conforme o andamento do projeto e as necessidades de aprovação dos Planos Diretores locais para, então, estabelecer ações relacionadas ao turismo, priorizando a educação ambiental. Por fim, reforçam seu papel quanto à autorização dos acessos ao lago desde que esses passem pela APP.

Após a triangulação dos dados identificou-se a necessidade de compreender o olhar dos empreendedores e dos órgãos públicos responsáveis pela temática da água, meio ambiente e turismo. Assim, foram entrevistados representantes dos consórcios das hidrelétricas, da Agência Nacional de Águas, do Instituto Brasileiro de Meio Ambiente e do Ministério do Turismo.

Os grupos responsáveis pela gestão dos empreendimentos, BAESA e Corumbá Concessões, destacam a coerência das políticas públicas e, de certa forma, o diálogo entre elas, mas sempre relacionados à questão regional, ou seja, ao que é regulamentado pelos estados atingidos. Apontam o IBAMA como principal agente controlador das ações desenvolvidas na região, atuando no monitoramento das ações estabelecidas pelo PACUERA/PCAU.

Já quanto ao turismo, destacam sua importância desde que utilizado de forma sustentável. Neste sentido, as ações desenvolvidas são diferenciadas, pois enquanto a Corumbá Concessões prioriza ações educativas de conscientização sobre a importância da preservação ambiental e aguarda as demandas das prefeituras locais, quanto a ações de turismo estabelecidas pelo Plano Diretor, a BAESA em parceria com oito dos nove municípios atingidos criou a Agência de Desenvolvimento da Região dos Lagos (ADREL), que concentra ações para o fomento do turismo a partir de parcerias com os governos estaduais e federal, priorizando a criação de infraestrutura de acesso, 
de condições de uso das águas por equipamentos náuticos e promoção do artesanato local.

Essa diferenciação nas ações deve-se, em parte, a cenários iniciais dicotômicos e distintos, pois a região de Corumbá IV durante o estudo de viabilidade já apresentava algumas estruturas para atendimento a turistas, enquanto na região de Barra Grande este movimento ainda se apresentava de forma incipiente, ou seja, sistematizar atividades em andamento torna-se complexo em relação a planejar e implementar ações de fomento.

Do ponto de vista dos órgãos federais observa-se certo conflito de entendimento sobre as competências quanto à prática do turismo nas regiões atingidas por lagos artificiais, pois, conforme dados coletado na entrevista 0 Ministério do Turismo (MTur) desconhece as políticas ambientais relacionadas ao PACUERA/PCAU, portanto, não atua de forma a acompanhar o desenvolvimento desse potencial turístico. Já o IBAMA afirma convidar os órgãos responsáveis para as discussões de ações propostas nas audiências públicas. A Agência Nacional de Águas assume sua responsabilidade de acompanhar o desenvolvimento do turismo nas águas desde que seja estabelecido pelo Plano de Recursos Hídricos.

Nota-se, portanto, total desencontro entre os órgãos do governo quanto à temática, apesar de estar presente em sítios eletrônicos oficiais, relatórios e outros documentos. Acredita-se que seja necessário o estreitamento do diálogo entre esses órgãos, possibilitando o desenvolvimento de ações efetivas e coordenadas.

Os discursos sobre meio ambiente e turismo precisam ultrapassar as barreiras ideológicas para se aproximar e permitir a atuação conjunta e sustentável sob a qual o homem e a natureza sejam beneficiados, pois é indiscutível que para a continuidade do turismo é necessária à conservação dos espaços naturais, por isso, seu uso racional torna-se elemento chave para qualquer debate. 


\section{CONSIDERAÇÕES FINAIS}

O fenômeno turístico ocorre nos espaços públicos e privados e, em muitos casos, de forma desordenada sem qualquer planejamento prévio, gerando prejuízos e comprometendo o meio ambiente natural e a cultura local. Por isso, é fundamental a associação do planejamento às políticas públicas, para permitir a efetividade das ações que envolvem o processo decisório e que determinará o desenvolvimento do turismo.

De outro lado, as barganhas estão presentes no cotidiano das organizações possibilitando a escolha das premissas que atenderão ao maior número de pessoas sem comprometer a continuidade das relações entre indivíduos, empreendedores e governos. As cidades tornam-se espaços capitalistas em expansão e turismo, assim como as culturas, transformam-se em aspectos fundamentais da economia política.

Por sua vez a visão economicista torna-se prioridade nos discursos, inibindo o entendimento do todo e, de forma indiscriminada, prejudicando a escolha das alternativas que permitem o progresso do turismo sustentável, que proteja as áreas naturais, incluindo as comunidades e valorizando as culturas. Agrega-se a esta afirmação o uso consciente dos ambientes naturais priorizando a continuidade das espécies e paisagens.

Um cenário de convivência pacífica entre ser humano e natureza deveria estar atrelado às regras estabelecidas pelos tomadores de decisão, que disciplinam os limites do homem em suas intervenções. Isso, portanto, enfatiza a relevância das políticas públicas. Assim, afirma-se que a partir das leis é possível discutir a atuação dos sujeitos, promovendo a melhoria da qualidade de vida da população, o crescimento econômico local e a conservação dos ambientes. 
Diante disso, cabe retomar os objetivos desse trabalho de forma a explicitar os resultados obtidos a partir da pesquisa desenvolvida e das ferramentas de análise elencadas.

Visando analisar as políticas que indicam o turismo como uma oportunidade de uso múltiplo das barragens, observou-se a necessidade de identificar quais seriam as leis, decretos e resoluções estabelecidas pelo Governo Federal para normatizar as atividades desenvolvidas nas áreas naturais consideradas bem da União. Destacam-se: a Constituição Federal de 1988, que dedica-se em seu Capítulo II à temática do turismo e do uso das águas de forma a direcionar a discussão sobre os direitos assegurados aos indivíduos e ao estado; a Lei 12.654/2012, que identifica o ecoturismo como uma ação de interesse social e a necessidade de áreas de preservação permanente em reservatórios artificiais como instrumentos de preservação dos recursos hídricos. Quanto às resoluções destacam-se as contribuições previstas na CONAMA 302/2002, que dispõe sobre os parâmetros e limites dos usos das Áreas de Preservação Permanente, apontando a obrigatoriedade da aprovação do PACUERA, instrumento que norteou as discussões desta dissertação.

Com o intuito de complementar a análise das políticas públicas buscando analisar a coerência entre as ações propostas no PACUERA/PECAU e sua prática, identificou-se pelas atas de audiência pública que as demandas repassadas aos gestores dos consórcios priorizaram aquelas relacionadas à educação ambiental para assim atingir não apenas o turista que visita a região por um período determinado, mas, principalmente, a comunidade local que recebe esses indivíduos e tem a oportunidade de os sensibilizar para boas práticas desenvolvidas na região.

Já as demais demandas como qualificação profissional, criação de Unidades de Conservação e preservação da memória, observa-se que algumas ações estão sendo desenvolvidas de forma pontual, dependendo em parte da interlocução do poder público local, responsável por determinar no Plano Diretor dos municípios as prioridades de execução que porventura poderão utilizar-se 
da compensação financeira paga pelas hidrelétricas aos municípios atingidos, conforme previsto nas Leis ํo.7.990/1989, 9.427/1996 e 9.648/1998, 12.858/2013.

Para identificar e discutir as ações propostas para o uso do turismo nos reservatórios, tendo como prioridade os interesses manifestados pela população local durante o processo de construção do relatório, fez-se necessária a utilização de reportagens veiculadas nas mídias digitais durante o período de 2000 a 2013 onde foram identificados os discursos apresentados pelos grupos de interesse que compõem o tripé núcleo duro, núcleo político e os aspectos institucionais e que determinam as crenças dos atores. Neste processo identificou-se a relevância das barganhas políticas e o poder que possuem para a aprovação de projetos considerados como de interesse coletivo. Essa análise mostrou pouca referência ao turismo e, nos momentos em que este tema foi suscitado, observou-se o uso inadequado do conceito para manipular as massas e favorecer a aprovação das propostas sob o argumento do desenvolvimento econômico e da distribuição da renda.

Foram utilizadas e analisadas, ainda, as atas de audiências públicas e reuniões que demonstram os interesses dos governos, empresários e da comunidade. Os primeiros, discursam a favor do crescimento regional e melhoria da qualidade de vida da comunidade. Os segundos defendem a importância dos empreendimentos e a responsabilidade assumida com os atingidos pela barragem. $\mathrm{E}$ os últimos exigem o pagamento das indenizações com maior agilidade além da possibilidade de acesso ao lago para prática de lazer e piscicultura.

As entrevistas foram esclarecedoras ao possibilitar o entendimento dos ruídos na comunicação entre as pastas envolvidas direta e indiretamente no processo de implantação de práticas turísticas, além de apontar os caminhos traçados pelos empresários após a aprovação do PACUERA/PCAU, considerando as regras determinadas pelas políticas públicas vigentes. 
Este caminho possibilitou, de forma abrangente, analisar as políticas públicas que discorrem sobre a problemática dessa dissertação e, permitiu a identificação das lacunas existentes no processo de construção do PACUERA/PCAU e do entendimento por parte dos atores sobre suas competências e poderes dentro das arenas de barganha estabelecidas pelo licenciamento prévio das hidrelétricas.

Não foram identificadas lacunas que inviabilizam o uso do turismo nos reservatórios, mas acredita-se que para as ações tornarem-se eficientes é fundamental a melhor organização dos municípios atingidos para que assim possam pleitear maior apoio por parte dos gestores da UHEs, no que tange à maximização dos benefícios individuais e coletivos. O modelo utilizado na região Sul, com a criação da ADREL, demonstra a força que a coletividade possui quando se organiza e apresenta demandas unificadas. Dessa forma, provavelmente o planejamento e gestão do turismo alcançará o desenvolvimento local de forma sustentável.

Alguns caminhos começam a ser traçados a partir dessa dissertação. Todavia, acredita-se na necessidade de outros trabalhos para assim preencher as possíveis lacunas deixadas. Assim, foram elencadas algumas propostas para trabalhos futuros como:

- O mapeamento dos atingidos pela barragem, de forma a identificar como visualizam o processo de desapropriação das terras e reocupação do espaço pelo turismo;

- A criação de metodologia de monitoramento do ciclo de vida do entorno do reservatório, possibilitando o acompanhamento e intervenção nas ações determinadas pelo planejamento estratégico de forma a evitar a insustentabilidade do turismo;

- A sistematização dos planos diretores dos municípios atingidos para identificar a visibilidade dada ao turismo e as possibilidades de atuação; e, por fim; 
- A criação de tecnologias inovadoras que priorizem o uso sustentável do solo e das águas dos lagos artificiais, considerando como elemento principal o turismo.

A princípio essa proposta será foco de estudos da autora nos estudos de doutoramento. 


\section{REFERÊNCIAS}

ÁGUAS DO BRASIL. Brasília: REBOB - Rede Brasil de Organismos de Bacia. Ano 4, n. 9, p.52, mar. 2014 . Disponível em http://aguasdobrasil.org/portfolio_item/edicao-9-2014-8o-forum-mundial-daagua-brasilia-brasil. Acesso em: 5 de janeiro de 2015 às 9h15

BACHELARD, Gaston. A casa: do portão ao sótão. O sentido da cabana. In: A poética do espaço. São Paulo: Martins Fontes, 1998. P.23 - 53

BAESA, Energética Barra Grande S/A; NCA, Núcleo de Consultoria Ambiental. 2005. Plano de conservação ambiental e usos da água e do entorno do reservatório - Relatório Consolidado R1. Florianópolis, v.1. 146p.

BAESA, Energética Barra Grande S/A; NCA, Núcleo de Consultoria Ambiental. 2005. Plano de conservação ambiental e usos da água e do entorno do reservatório - Relatório Consolidado R1. Florianópolis, v.2.166p

BENI, Mario Carlos. Análise Estrutural do Turismo. 8 ED. São Paul: SENAC, 2003. 523p.

Sistema de Turismo. In. Turismo em Análise. São Paulo, V.1, n.1, 1990. Disponível em: < http://www.revistas.usp.br/rta/article/view/63854>. Acesso em: 1 de setembro de 2014 às $22 \mathrm{~h} 45$

BERTALANFFY, Ludwing Von. Teoria geral dos sistemas: fundamentos, desenvolvimento e aplicações. Petropolis, RJ: Vozes, 2012. 360p.

BOFF, Leonardo. Virtudes para um outro mundo possível: Hospitalidade. Petropolis, RJ: Vozes, 2005. 199p.

BOULLÓN, Roberto; MOLINA, Sérgio; WOOG, Manuel Rodriguez. Um novo Tempo livre: três enfoques teórico-prático. Bauru, SP: Edusc, 2004. 116p.

BORGES, Cristiano Araujo. Sustentabilidade: utilização indiscriminada nas políticas do turismo brasileiro. (Dissertação de Mestrado). Programa de PósGraduação em Geografia, Universidade de Brasília, 2013. 177 p.

BRASIL. Câmara Legislativa. Decreto 1.915 de 27 de dezembro de 1939. Cria o departamento de Imprensa e Propaganda e dá outras providencias. Disponível em: < http://www2.camara.leg.br/legin/fed/declei/1930-1939/decreto-lei-191527-dezembro-1939-411881-publicacaooriginal-1-pe.html >. Acesso em: 8 de julho de 2014 às $12 \mathrm{~h} 20$

BRASIL. Constituição (1988). Constituição da República Federativa do Brasil: promulgada em 5 de outubro de 1988. Disponível em: < http://www.planalto.gov.br/ccivil_03/constituicao/constituicao.htm> Acesso em 10 de junho de 2014 às 7 h23 
BRASIL. Decreto Lei no 24.643 de 10 de julho de 1934. Código de Águas. Disponível em: < http://www.leffa.pro.br/textos/abnt.htm> Acesso em: 9 de outubro de 2014 , às $15 \mathrm{~h} 50$

BRASIL. Decreto no 448 de 14 de fevereiro de 1992. Regulamenta dispositivos da Lei $n^{\circ}$ 8.181, de 28 de março de 1991, dispõe sobre a Política Nacional de Turismo e dá outras providências. Disponível em: < http://www.planalto.gov.br/ccivil_03/decreto/1990-1994/D0448.htm> Acesso em: 05 de julho de 2014 às 17 h20

Brasil. Ministério do Meio Ambiente. Resolução CONAMA no 6 de 24 de janeiro de 1986. Aprovar os modelos de publicação de pedidos de licenciamento em quaisquer de suas modalidades, sua renovação e a respectiva concessão e aprova os novos modelos para publicação de licenças, conforme instruções abaixo especificada. Disponível em: <http://www.mma.gov.br/port/conama/res/res86/res0686.html>. Acesso em: 5 de junho de 2014 às 7h55

Brasil. Ministério do Meio Ambiente. Resolução CONAMA no 25 de 7 de dezembro de $19946 . \quad$ Disponível em: < http://www.mma.gov.br/port/conama/res/res94/res2594.html>. Acesso em: 3 de junho de 2014 às 7h55

Brasil. Ministério do Meio Ambiente. Resolução CONAMA no 237 de 19 de dezembro de 1997. Para efeito desta Resolução são adotadas as seguintes definições.

Disponível em:

http://www.mma.gov.br/port/conama/res/res97/res23797.html>. Acesso em: 5 de junho de 2014 às 7 h03

Brasil. Ministério do Meio Ambiente. Resolução CONAMA no 302 de 20 de março de 2002. Dispõe sobre os parâmetros, definições e limites de Áreas de Preservação Permanente de reservatórios artificiais e o regime de uso do entorno. Disponível em: <http://www.mma.gov.br/port/conama/res/res02/res30202.html Acesso em: 5 de junho de 2014 às $7 \mathrm{~h} 28$

Brasil. Ministério do Meio Ambiente. Resolução CNRH no 16 de 8 de maio de 2001. Disponível em: < file:///C:/Users/Mario/Downloads/resolucao_16-\%20(1).pdf>. Acesso em: 5 de junho de 2014 às 7h52

BRASIL. Ministério do Turismo. Marcos conceituais. MTur: Brasília, 2008. 55p.

BRASIL. Ministério do Turismo. Turismo Náutico: orientações básicas. MTur: Brasília, 2008. 34p.

BRASIL. Ministério do Turismo. Turismo de pesca: orientações básicas. MTur: Brasília, 2008. 54p. 
BRASIL. Medida Provisória $\mathrm{n}^{\circ}$ 2.216-37 de 31 de agosto de 2001. Altera dispositivos da Lei no 9.649, de 27 de maio de 1998, que dispõe sobre a organização da Presidência da República e dos Ministérios, e dá outras providências. Disponível em: < http://www.planalto.gov.br/ccivil_03/mpv/221637.htm>. Acesso em 5 de outubro de 2014, às $17 \mathrm{~h} 38$

BRASIL. Presidência da República. Decreto de 22 de março de 2005. Institui a Década Brasileira da Água, a ser iniciada em 22 de março de 2005. Disponível em: http://presrepublica.jusbrasil.com.br/legislacao/96818/decreto-05, Acesso em 5 de outubro de 2014, às 8h53

BRASIL. Presidência da República. Decreto lei no 55 de 18 de novembro de 1966. Define a política nacional de turismo, cria o Conselho Nacional de Turismo e a Empresa Brasileira de Turismo, e dá outras providências. Disponível em: < http://www.planalto.gov.br/ccivil_03/decreto/D2612.htm>. Acesso em: 05 de julho de 2014 às $13 \mathrm{~h} 22$

BRASIL. Presidência da República. Decreto lei no 2.612 de 3 de junho de 1998. Regulamenta o Conselho Nacional de Recursos Hídricos, e dá outras providências. Disponível em: < http://www.planalto.gov.br/ccivil_03/decretolei/1965-1988/Del0055.htm>. Acesso em: 05 de julho de 2014 às $13 \mathrm{~h} 22$

BRASIL. Lei $\mathbf{n}^{\circ} \mathbf{4 7 7 1}$ de 15 de setembro de 1965. Institui o Novo Código Florestal. Disponível em: < http://www.planalto.gov.br/ccivil_03/leis/l4771.htm> Acesso em: 05 de julho de 2014 às $13 \mathrm{~h} 48$

BRASIL. Lei no 6.938 de 31 de agosto de 1981. Dispõe sobre a Política Nacional do Meio Ambiente, seus fins e mecanismos de formulação e aplicação, e dá outras providências. Disponível em: < http://www.planalto.gov.br/ccivil_03/leis/l6938.htm>. Acesso em: 9 de outubro de 2014, às $18 \mathrm{~h} 01$

BRASIL. Lei no 7.735 de 22 de fevereiro de 1989. Dispõe sobre a extinção de órgão e de entidade autárquica, cria o Instituto Brasileiro do Meio Ambiente e dos Recursos Naturais Renováveis e dá outras providências. Disponível em: < http://www.planalto.gov.br/ccivil_03/leis/l7735.htm>. Acesso em: 9 de outubro de 2014, às $18 \mathrm{~h} 37$

BRASIL. Lei no 8.118 de 28 de março de 1991. Dá nova denominação à Empresa Brasileira de Turismo (Embratur), e dá outras providências. Disponível em: <http://www.planalto.gov.br/ccivil_03/leis/L8181.htm>. Acesso em: 05 de julho de 2014 às $13 \mathrm{~h} 40$

BRASIL. Lei no 8.490 de 19 de novembro de 1993. Dispõe sobre a organização da Presidência da República e dos Ministérios e dá outras providências. Disponível em: < http://www.planalto.gov.br/ccivil_03/leis/L8490.htm>. Acesso em: 10 de outubro de 2014 , às 09 h30 
BRASIL. Lei no 9,433, de 8 de janeiro de 1997. Institui a Política Nacional de Recursos Hídricos, cria o Sistema Nacional de Gerenciamento de Recursos Hídricos, regulamenta o inciso XIX do art. 21 da Constituição Federal, e altera o art. 1ำ da Lei $n^{\circ}$ 8.001, de 13 de março de 1990, que modificou a Lei $n-7.990$, de 28 de dezembro de 1989. Disponível em: < http://www.planalto.gov.br/ccivil_03/leis//9433.htm>. Acesso em: 9 de outubro de 2014, às $15 \mathrm{~h} 33$

BRASIL. Lei no 9.984 de 17 de julho de 2000. Dispõe sobre a criação da Agência Nacional de Águas - ANA, entidade federal de implantação da Política Nacional de Recursos Hídricos e de coordenação do Sistema Nacional de Gerenciamento de Recursos Hídricos, e dá outras providências. Disponível em: < http://www.planalto.gov.br/ccivil_03/leis//9984.htm>. Acesso em: 9 de outubro de 2014, às $11 \mathrm{~h} 47$

BRASIL. Lei no 10.683 de 28 de maio de 2003. Dispõe sobre a organização da Presidência da República e dos Ministérios, e dá outras providências. Disponível em: < http://www.planalto.gov.br/ccivil_03/leis/2003/L10.683compilado.htm>. Acesso em: 9 de outubro de 2014, às 15h47

Brasil. Lei $\mathrm{n}^{\circ}$ 11.105, de 24 de março de 2005. Regulamenta os incisos II, IV e V do $\S 10$ do art. 225 da Constituição Federal, estabelece normas de segurança e mecanismos de fiscalização de atividades que envolvam organismos geneticamente modificados - OGM e seus derivados, cria o Conselho Nacional de Biossegurança - CNBS, reestrutura a Comissão Técnica Nacional de Biossegurança - CTNBio, dispõe sobre a Política Nacional de Biossegurança PNB, revoga a Lei no 8.974, de 5 de janeiro de 1995, e a Medida Provisória no 2.191-9, de 23 de agosto de 2001, e os arts. 5o, 6o, 7o, 8o, 9o, 10 e 16 da Lei no 10.814 , de 15 de dezembro de 2003, e dá outras providências. Disponível em: <http://www.planalto.gov.br/ccivil_03/_ato2004-2006/2005/lei/l11105.htm>. Acesso em: 9 de outubro de 2014, às $11 \mathrm{~h} 07$

BRASIL. Lei $\mathbf{n}^{\circ} \mathbf{1 1 . 5 1 6}$ de 28 de agosto de 2007. Dispõe sobre a criação do Instituto Chico Mendes de Conservação da Biodiversidade - Instituto Chico Mendes; altera as Leis nos 7.735, de 22 de fevereiro de 1989, 11.284, de 2 de março de 2006, 9.985, de 18 de julho de 2000, 10.410, de 11 de janeiro de 2002, 11.156, de 29 de julho de 2005, 11.357, de 19 de outubro de 2006, e 7.957, de 20 de dezembro de 1989; revoga dispositivos da Lei no 8.028, de 12 de abril de 1990, e da Medida Provisória no 2.216-37, de 31 de agosto de 2001; e dá outras providências. Disponível em: < http://www.planalto.gov.br/ccivil_03/_ato20072010/2007/lei/l11516.htm>. Acesso em: 10 de outubro de 2014, às 09h05

BRASIL. Lei $\mathbf{n}^{\circ} \mathbf{1 1 . 7 7 1}$ de 17 de setembro de 2008. Dispõe sobre a Política Nacional de Turismo, define as atribuições do Governo Federal no planejamento, desenvolvimento e estímulo ao setor turístico; revoga a Lei no 6.505, de 13 de dezembro de 1977, o Decreto-Lei no 2.294, de 21 de novembro de 1986, e dispositivos da Lei no 8.181, de 28 de março de 1991; e dá outras providências. 
Disponível em: < http://www.planalto.gov.br/ccivil_03/_ato20072010/2008/lei/l11771.htm>. Acesso em: 2 de agosto de 2014

BRASIL. Lei $\mathbf{n}^{\circ} \mathbf{1 2 . 6 5 1}$ de $\mathbf{2 5}$ de maio de 2012. Dispõe sobre a proteção da vegetação nativa; altera as Leis nos 6.938, de 31 de agosto de 1981, 9.393, de 19 de dezembro de 1996, e 11.428, de 22 de dezembro de 2006; revoga as Leis nos 4.771 , de 15 de setembro de 1965, e 7.754 , de 14 de abril de 1989, e a Medida Provisória no 2.166-67, de 24 de agosto de 2001; e dá outras providências. Disponível em: < http://www.planalto.gov.br/ccivil_03/_ato20112014/2012/lei/l12651.htm>. Acesso em: 05 de julho de 2014 às $1 \overline{4} \mathrm{~h} 27$

BRASIL. Ministério do Turismo. Plano Nacional de Turismo: 0 turismo fazendo muito mais pelo Brasil 2013 - 2016. Disponível em: http://www.turismo.gov.br/export/sites/default/turismo/o_ministerio/publicacoes/ downloads_publicacoes/plano_nacional_2013.pdf Acesso em: 30/03/2014 às 15:51

BRUYNE, Paul de; HERMAN, Jacques; SCHOUTHEETE, Marc de. Dinâmica da pesquisa em ciências sociais. 3. Ed. Rio de Janeiro: Francisco Alves,1997. 252p.

BUARQUE, S. C. Metodologia de planejamento e desenvolvimento local e municipal sustentável: material para orientação técnica e treinamento de multiplicadores e técnicos em planejamento local e municipal. Brasília: PCT INCRA/IICA, 1999. $105 \mathrm{p}$.

CARMO, F. Planos regionais de ordenamento do território e governança territorial: do discurso às evidencias da prática. Revista de Geografia e Ordenamento do Território. № 5 (jun/2014), p. 41-65

CASTELLI, Geraldo. Hospitalidade: a inovação na gestão das organizações prestadoras de serviços. Saraiva, São Paulo, SP: 2010. 259p.

DEMO, Pedro. Metodologia do conhecimento científico. São Paulo, SP: Atlas, 2013. 216p.

COOPER, Chris; FLETCHER, John; WANHILL, Stephen; GILBERT, David; SHEPHERD, Rebecca; Turismo: princípios e prática. Porto Alegre: Bookman, 1998.

DENCKER, Ada de Freitas Maneti. Métodos e técnicas de pesquisa em turismo. 4 ed. São Paulo, SP: Futura, 2000, 286p.

DENZIN, Norman K.; LINCOLN, Yvonna S. O planejamento da pesquisa qualitativa: teorias e abordagens. 2. Ed. Porto Alegre, RS: Penso 2006. 432p.

DERRIDA, Jacques. Anne Dufourmantelle convida Jacques Derrida a falar Da Hospitalidade. São Paulo: Escuta, 2003.135p. 
FERREIRA, Roberta Celestino; LOPES, Wilza Gomes Reis; ARAUJO, José Luis Lopes. A água como suporte para atividades de lazer e turismo: possibilidades e limitações da barragem Piracuruca no estado do Piauí (Brasil). RA'EGA Espaço Geográfico em análise. Curitiba, PR v. 25, p.134 - 163, 2012.

FOUCAULT, Michael . O governo de si e dos outros. São Paulo, SP: Martins Fontes, 2013. 400p.

GIL, Antonio Carlos. Métodos e técnicas de pesquisa social. 5ee․ São Paulo, SO: Atlas, 2007. 206p.

GORNI, Patricia Monteiro; DREHER, Marialva Tomio. Estratégias intersetoriais no desenvolvimento do turismo de natureza: desafios e perspectivas. Turismo em Análise. São Paulo, SP: v. 21, no3, p. 567 - 593, 2010.

GRINOVER, Lúcio. A hospitalidade, a cidade e o turismo. São Paulo, SP: Aleph, 2007. 191 p.

GUTIERREZ, Gustavo Luís. Lazer e prazer: questões metodológicas e alternativas políticas. Campinas, SP: Autores Associados, 2001. 125p.

HARVEY, David. A produção capitalista do espaço. São Paulo, SP: Annablume, 2005. 252p.

IBGE, Instituto Brasileiro de Geografia Espacial. 2014: Anita Garibaldi (SC) Disponível em:

http://www.cidades.ibge.gov.br/xtras/perfil.php?lang=\&codmun=420100\&search =santa-catarina|anita-garibaldi>. Acesso em: 23 de novembro de 2014 às 8h15

IBGE, Instituto Brasileiro de Geografia Espacial. 2014: Bom Jesus (SC) Disponível em: http://www.cidades.ibge.gov.br/xtras/perfil.php?lang=\&codmun=420253\&search =santa-catarina|bom-jesus $>$. Acesso em: 23 de novembro de 2014 às 8h47.

IBGE, Instituto Brasileiro de Geografia Espacial. 2014: Campo Belo do Sul (SC) Disponível em:

http://www.cidades.ibge.gov.br/xtras/perfil.php?lang=\&codmun=420340\&search =santa-catarina|campo-belo-do-sul>. Acesso em: 23 de novembro de 2014 às 8h59.

IBGE, Instituto Brasileiro de Geografia Espacial. 2014: Capão Alto (SC) Disponível em: http://www.cidades.ibge.gov.br/xtras/perfil.php?lang=\&codmun=420325\&search =santa-catarina $\mid$ capao-alto $>$. Acesso em: 23 de novembro de 2014 às 9h17.

IBGE, Instituto Brasileiro de Geografia Espacial. 2014: Cerro Negro (SC) Disponível em: http://www.cidades.ibge.gov.br/xtras/perfil.php?lang=\&codmun=420417\&search =santa-catarina|cerro-negro $>$. Acesso em: 23 de novembro de 2014 às 9h17. 
IBGE, Instituto Brasileiro de Geografia Espacial. 2014: Esmeralda (RS) Disponível em: http://www.cidades.ibge.gov.br/xtras/perfil.php?lang=\&codmun=430740\&search =rio-grande-do-sul|esmeralda>. Acesso em: 23 de novembro de 2014 às 9h23.

IBGE, Instituto Brasileiro de Geografia Espacial. 2014: Lages (SC) Disponível em:

<http://www.cidades.ibge.gov.br/xtras/perfil.php?lang=\&codmun=420930\&searc $\mathrm{h}=$ santa-catarina|lages $>$. Acesso em: 23 de novembro de 2014 às $9 \mathrm{~h} 35$.

IBGE, Instituto Brasileiro de Geografia Espacial. 2014: Vacaria (RC) Disponível em:

http://www.cidades.ibge.gov.br/xtras/perfil.php?lang=\&codmun=432250\&search =rio-grande-do-sul|vacaria>. Acesso em: 23 de novembro de 2014 às $10 \mathrm{~h} 10$.

IBGE, Instituto Brasileiro de Geografia Espacial. 2014: Abadiânia (GO) Disponível http://www.cidades.ibge.gov.br/xtras/perfil.php?lang=\&codmun=520010\&search $=$ goias $\mid$ abadiania $>$. Acesso em: 17 de dezembro de 2014 às $11 \mathrm{~h} 13$.

IBGE, Instituto Brasileiro de Geografia Espacial. 2014: Alexânia (GO) Disponível em

$<$ http://www.cidades.ibge.gov.br/xtras/perfil.php?lang=\&codmun=520030\&searc $\mathrm{h}=$ goias $\mid$ alexania $>$. Acesso em: 17 de dezembro de 2014 às $13 \mathrm{~h} 10$

IBGE, Instituto Brasileiro de Geografia Espacial. 2014: Corumbá de Goiás (GO) Disponível em

http://www.cidades.ibge.gov.br/xtras/perfil.php?lang=\&codmun=520580\&search $=$ goias $\mid$ corumba-de-goias $>$. Acesso em: 17 de dezembro de 2014 às $13 \mathrm{~h} 36$

IBGE, Instituto Brasileiro de Geografia Espacial. 2014: Gameleira de Goiás

(GO) Disponível em < http://www.cidades.ibge.gov.br/xtras/perfil.php?lang=\&codmun=520815\&search $=$ goias $\mid$ gameleira-de-goias $>$. Acesso em: 17 de dezembro de 2014 às $14 \mathrm{~h} 32$

IBGE, Instituto Brasileiro de Geografia Espacial. 2014: Luziânia (GO) Disponível em

<http://www.cidades.ibge.gov.br/xtras/perfil.php?lang=\&codmun=521250\&searc $\mathrm{h}=$ goias/luziania $>$. Acesso em: 17 de dezembro de 2014 às $14 \mathrm{~h} 25$

IBGE, Instituto Brasileiro de Geografia Espacial. 2014: Novo Gama(GO) Disponível em<http://www.cidades.ibge.gov.br/xtras/perfil.php?lang=\&codmun=521523\&se arch=goias|novo-gama $>$. Acesso em: 17 de dezembro de 2014 às $15 \mathrm{~h} 15$

IBGE, Instituto Brasileiro de Geografia Espacial. 2014: Santo Antônio do Descoberto (GO) Disponível em < http://www.cidades.ibge.gov.br/xtras/perfil.php?lang=\&codmun=521975\&search 
=goias|santo-antonio-do-descoberto>. Acesso em: 17 de dezembro de 2014 às $15 \mathrm{~h} 47$

IBGE, Instituto Brasileiro de Geografia Espacial. 2014: Silvânia(GO) Disponível em

http://www.cidades.ibge.gov.br/xtras/perfil.php?lang=\&codmun=522060\&search $=$ goias|silvania $>$. Acesso em: 17 de dezembro de 2014 às $16 \mathrm{~h} 23$

IPEA, Instituto de Pesquisa Econômica Aplicada. Atlas do Desenvolvimento Humano no Brasil. 2010. Disponível em: < http://www.atlasbrasil.org.br/2013/pt/> Acesso em: 23 de novembro de 2014 às $13 \mathrm{~h} 15$

JAFARI, Jafari. El Turismo como disciplina científicia. In. Politica y sociedad, v42, $\quad$ n.1, p.39-56, $2005 . \quad$ Disponível em: https://www.academia.edu/6019927/EI_turismo_como_disciplina_cientifica_The _Scientification_of_Tourism. Acesso em:17 de setembro de 2014 às $10 \mathrm{~h} 30$

JONES, Bryan D.; BAUMGARTNER Frank R.. From There to Here: Punctuated Equilibrium to the General Punctuation Thesis to a Theory of Government Information Processing. The Policy Studies Journal, 2012: 1-19

KINGDON, John W. Agendas, Alternatives ad Public Policies. Boston: Longman, 2011

KRIPPENDORF, Jost. Sociologia do turismo: para uma nova compreensão do lazer e das viagens. São Paulo: Aleph, 2001. 184p

LASHLEY, Conrad; MORRISON, Alison. Em busca da hospitalidade: perspectivas para um mundo globalizado. Barueri, SP: Manole, 2004. 424p.

LEFF, Enrique. Epistemologia ambiental. São Paulo, 5ae ed. Ed. Cortez Editora, 2010. $239 \mathrm{p}$.

LEIPER, Neil. The framework of tourism towards a definition of tourism, turist, and the tourist industry. Annals of Tourism Research, Great Britain: Pergamon, v. 6, p. 390-407, 1979.

MACHADO, Danielle Fernandes Costa. COSLING, Marlusa. A teoria geral do sistema na ótica do turismo: uma revisão dos modelos de sistemas turrísticos. Inn Seminário da Associação Brasileira de Pesquisa e Pós-Graduação em Turismo, 6, 2009, São Paulo. Anais...São Paulo: Associação Brasileira de Pesquisa e Pós-Graduação em Turismo, 2009. Disponível em: http://www.anptur.org.br/ocs/index.php/seminario/2009/paper/view/131/25>.

Acesso em: 2 de setembro de 2014 às 08h58

MALDONADO, Mauro. O estrangeiro. In: Raízes Errantes. São Paulo: Ed. 34, 204. P. 29-34 
MANSKI, Charles. Policy Analysis with Increduble Certitude. Working paper 16207. National Bureau ofEconomicResearch. Cambridge: MA, July, 2010.

$\mathrm{MARCH}$, James G. Como as Decisões Realmente Acontecem: princípios de tomada de decisões. São Paulo: Editora Leopardo, 2009. 241p.

MARCELINO, Nelson Carvalho. Estudo do lazer: uma introdução. Campinas, SP: 3aㅡ ed. Autores Associados, 2002. 97p.

MCINTOSH, Robert. Turismo princípios, práticas e filosofias. Porto Alegre: Bookman, 2002.

MELO, Alessandro de. A construção do objeto turístico: diálogos com a epistemologia de Gaston Bachelard e Pierre Bourdieu. In. Seminário de Pesquisa em turismo do MERCOSUL.4, 2006. Caxias do Sul, RS. ANAIS. Universidade de Caxias do Sul, 2007. Disponível em: <file:///C:/Users/Mario/Downloads/GT14-10.pdf>. Acesso em: 24 de setembro 2014 às $15 \mathrm{~h} 48$

MOESCH, Marutschka M. Epistemologia social do Turismo. 2004, Tese (Doutorado) - Escola de Comunicação e Arte, Universidade de Brasilia USP, São Paulo, 2004. 500p.

A origem do conhecimento, o lugar da experiência e da razão na gênese do conhecimento do turismo. In $5 \cong$ Congresso LatinoAmericano de Investigação Turística. Disponível em: <http://www.intranet.cet.unb.br/portal/images/stories/divulgacao/maruska.pdf >. Acesso em: 7 de setembro de 2014às $20 \mathrm{~h} 15$

MOLINA, Sergio. Turismo e ecologia. Bauru: Edusc, 2001. 222p.

Turismo: metodologia e planejamento. Bauru: Edusc, 2005.

$126 p$

MOLINA, Sergio; RODRIGUES, Sérgio. Planejamento Integral do turismo. Bauru: Edusc, 2001. 176p.

Organização Mundial do Turismo (1994) Desenvolvimento do turismo sustentável: manual para organizadores locais, 1994.

ONFRAY, Michel. Teoria da Viagem: poética da geografia. Porto Alegre: L\&PM editores, 2009. 112p.

PANOSSO NETO, ALEXANDRE. Filosofia do Turismo: Teoria e Epistemologia. 1ª Edição. São Paulo: Aleph, 2005. 160p.

PAVIANI, Jaime. Epistemologia prática - ensino e conhecimento científico. Caxias do Sul: EDUCS, 2009. 144p. 
PELLEGRIN, Ana de. Lazer, corpo e sociedade: articulações críticas e resistências políticas. In: PADILHA, Valquiria (org). Dialética do lazer. São Paulo, SP: Cortez, 2006. 286p.

PIMENTEL, Mariana Pereira Chaves. PIMENTEL, Thiago Duarte. CARRIERI, Alexandre de Pádua. Autopoiese e sistema turístico. In Observatório de Inovação Turística - Revista Acadêmica. Rio de Janeiro, V.8, n.1, 2014. Disponível em: <www.ebape.fgv.br/revistaoit $\geq$ Acesso em: 10 de setembro de 2014 às $10 \mathrm{~h} 42$

PNUD, Programa das Nações Unidas para o Desenvolvimento. Atlas do Desenvolvimento Humano no Brasil

PREFEITURA MUNICIPAL DE LAGES. 2014 Disponível em: <http://www.lages.sc.gov.br/novo/noticias/1457>. Aceso em: 23 de novembro de 2014 às $9 h 51$.

PREFEITURA MUNICIPAL DE ABADIÂNIA. 2014. Disponível em < http://www.cidades.ibge.gov.br/xtras/perfil.php?lang=\&codmun=520010>.

Aceso em: 17 de dezembro de 2014 às 15:57

PREFEITURA MUNICIPAL DE ALEXANIA. 2014. Disponível em < http://www.cidades.ibge.gov.br/xtras/perfil.php?lang=\&codmun=520030>.

Aceso em: 17 de dezembro de 2014 às 16:32

PRONOVOST, Gilles. Introdução à sociologia do lazer. São Paulo, SP: Senac, 2011. 203p.

SABATIER, Paul A.; WEIBLE, Christopher M. The Advocacy Coalition Framework: Innovations and Clarifications. In: SABATIER, Paul A. (Ed.). Theories of the Policy Process. 2. ed. Boulder: Westview Press, 2007. p. 189220

SACHS, Ignacy. Caminhos para o desenvolvimento sustentável. Rio de Janeiro: Garamond,2009. 96p.

SAQUET, Marcos Aurelio; SILVA, Sueli Santos da. Milton santos: concepções de geografia, espaço e território. GEOUERJ. V.2, n.18: p.24-42, 2008. Disponível

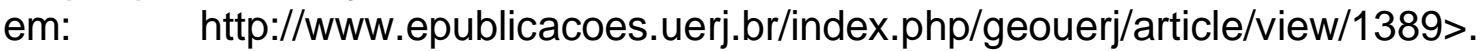
Acesso em: 28 de julho de 2014 às $10 \mathrm{~h} 54$

SANTOS, Milton. Espaço e método. São Paulo, SP: $5^{\mathfrak{a}}$ ed. Editora Universidade de São Paulo, 2008. 118p.

SESSA, Alberto. Turismo e política de desenvolvimento. Porto Alegre: Uniontur, 1983. 167p.

SILVA, Lívia Cristina Barros da. Turismo Sustentável: uma alternativa para minimizar os impactos das hidrelétricas. 2009. 61 f. Monografia (especialização) - Centro de Excelência em Turismo, Universidade de Brasília, Brasília 2009. 
SONAGLIO, KerleiEniele. Transdisciplinar o turismo: um ensaio sobre a base paradigmática making. In: Pasos - Revista de Turismo Y Patrimonio Cultural. V.11, n.1, p. 205-216, 2013. Disponível em: <http://www.pasosonline.org/Publicados/11113/PS0113_15.pdf>. Acesso em: 11 de setembro de 2014 às $11 \mathrm{~h} 17$

SOUZA, Silvana do Rocio; BAHI, Miguel; KUSHANO, Elizabete Sayuri. O espaço do turismo: produção, apropriação e transformação do espaço social. In: Revista Hospitalidade. São Paulo, v. X, n.2, 2013

TRIVIÑOS, Augusto N.S. Introdução á pesquisa em ciências sociais: a pesquisa qualitativa em educação. São Paulo: Atlas, 2012, 175 p.

TORO, José Bernardo. A construção do público: cidadania, democracia e participação. Rio de Janeiro, Ed. Senac, 2005. 112p.

VASCONCELOS, Fabricio Peixoto et al. Turismo de aventura e ecoturismo: entre práticas e normas no contexto brasileiro. Revista Iberoamericana de turismo. V.2, n.2, p. 108 - 138, jul./dez. 2012

VEIGA, José Eli da. Desenvolvimento sustentável: o desafio do século XXI. Rio de Janeiro: Garamond, 2010. 220p.

WALM ENGENHARIA E TECNOLOGIA AMBIENTAL LTDA. 2011. Plano ambiental de conservação e uso do entorno do reservatório da UHE Corumbá IV. 137p.

WEARING, Stephen; NEIL, John. Ecoturismo: impactos, potencialidades e possibilidades. Barueri, SP: Manole, 2001. 255p.

YIN, Robert K. Estudo de caso: planejamento e métodos. 2 ed. Porto Alegre: Bookman, 2001. 205p. 


\section{APENDICE}

\section{Roteiro de Entrevista aplicado aos Órgãos Federais}

1. Como a (Instituição) entende o turismo e suas contribuições para o meio ambiente?

2. Existe diálogo entre as políticas públicas ambientais e as políticas públicas do turismo? Em quais? E como é feita a gestão destas políticas em comum?

3. Após a Resolução CONAMA 2002 qual foi o prazo estabelecido para exigir a adequação dos projetos de hidrelétricas? Qual critério foi utilizado para estabelecer a partir de qual estágio de licenciamento esta adequação seria necessária?

4. No processo de aprovação do Plano Ambiental de Uso do Entorno do Reservatório Artificial - PACUERA existe a etapa de avaliação das ações previstas para o uso do turismo. Quais critérios são utilizados para esta análise?

5. A (Instituição) possui alguma ação de monitoramento e fiscalização das ações previstas para o desenvolvimento ou implantação do turismo?

6. Dentro do processo de concessão previsto pelo licenciamento está estabelecido a avaliação parcial das ações previstas no PACUERA. Qual a frequência e a quem compete esta avaliação?

7. Para a (Instituição) a política publica estabelecida pelo PACUERA é efetiva nas ações de fomento ao turismo? 


\section{Roteiro de Entrevista aplicado aos Órgãos Federais}

1. Como o (Empreendedor) entende o turismo e suas contribuições para o meio ambiente?

2. Existe diálogo entre as políticas públicas ambientais e as políticas públicas do turismo? Em quais? E como é feita a gestão destas políticas em comum?

3. No processo de aprovação do Plano Ambiental de Uso do Entorno do Reservatório Artificial - PACUERA existe a etapa de avaliação das ações previstas para o uso do turismo. Quais critérios são utilizados para esta análise?

4. $O$ (Empreendedor) possui alguma ação de monitoramento das ações previstas para o desenvolvimento ou implantação do turismo?

5. Dentro do processo de concessão previsto pelo licenciamento está estabelecido a avaliação parcial das ações previstas no PACUERA. Qual a frequência e a quem compete esta avaliação?

6. Para o (Empreendedor) a política pública estabelecida pelo PACUERA é efetiva nas ações de fomento ao turismo?

7. Qual o cenário atual de desenvolvimento do turismo na região atingida pelo (Empreendedor)? Quais atividades já estão implantadas? 